Florida International University FIU Digital Commons

3-24-2003

\title{
Ficción de Racionalidad: La memoria como operador mítico en las estéticas polares de Jorge Luis Borges y José Lezama Lima
}

José R. Vilahomat

Florida International University, jvilah01@fiu.edu

DOI: $10.25148 /$ etd.FI08081548

Follow this and additional works at: https://digitalcommons.fiu.edu/etd

\section{Recommended Citation}

Vilahomat, José R., "Ficción de Racionalidad: La memoria como operador mítico en las estéticas polares de Jorge Luis Borges y José Lezama Lima" (2003). FIU Electronic Theses and Dissertations. 29.

https://digitalcommons.fiu.edu/etd/29 


\section{FLORIDA INTERNATIONAL UNIVERSITY}

Miami, Florida

\section{FICCIÓN DE RACIONALIDAD: LA MEMORIA COMO OPERADOR MÍTICO EN LAS ESTÉTICAS POLARES DE JORGE LUIS BORGES Y JOSÉ LEZAMA LIMA}

A dissertation submitted in partial fulfillment of the requirements for the degree of DOCTOR OF PHILOSOPHY in SPANISH

by

José R. Vilahomat 
To: Dean Arthur W. Herriott

College of Arts and Sciences

This dissertation, written by José R. Vilahomat, and entitled Ficción de racionalidad: La memoria como operador mítico en las estéticas polares de Jorge Luis Borges y José Lezama Lima, having been approved in respect to style and intellectual content, is referred to you for judgment.

We have read this dissertation and recommend that it be approved.

$\begin{array}{r}\hline \text { Florence Yudin } \\ \hline \text { María Marín Santiago } \\ \hline \text { Reinaldo Sánchez } \\ \hline \text { Santiago Juan-Navarro, Major Professor }\end{array}$

Date of Defense: March 24, 2003

The dissertation of José R. Vilahomat is approved.

$\begin{array}{r}\begin{array}{r}\text { Dean Arthur W. Herriott } \\ \text { University Graduate School }\end{array} \\ \hline \begin{array}{c}\text { Dean Douglas Wartzok } \\ \text { University Graduate School }\end{array}\end{array}$

Florida International University, 2003 
(C) Copyright 2003 by José R. Vilahomat

All rights reserved. 


\section{DEDICATORIA}

A Pedro González, in memoriam. 


\section{AGRADECIMIENTOS}

La culminación de este proceso de crecimiento humano, cuya esteriorización formal es esta tesis, ha sido posible y pertenece en parte a las siguientes menciones. La profesora Florence Yudin fue una constante inspiración de amor a la poesía y a la labor intelectual. Su trabajo de edición de presición olímpica y sus consejos conceptuales han sido imprescindibles. La profesora María Marín Santiago, cuyo apoyo viene desde los primeros balbuceos intertextuales, me ha ayudado a ver proporciones invisibles, a tejer mejor el lenguaje para el "otro." El profesor Reinaldo Sánchez ha practicado un humanismo que sobrepasa el apoyo académico. Su desprendimiento y anhelo, al par de su potente logos me comprometen a unírmele. El profesor Santiago Juan-Navarro ha velado esta tesis como a un niño pequeño. Ha cuidado de la sustancia, ha sugerido insustituibles conceptos, ha dialogados con cada una de sus páginas. A Ellos agradezco profundamente esta conjunción. A los especialistas del departamento de graduados agradesco su ayuda constante y su amable sentido de orientación, especialmente a Nancy I. Colón y a Nanett Rojas. Agradesco a mis padres su apoyo moral y material, y a mi compañera su labor de retaguardia constante. ¡Bienvenidos todos a esta fiesta verbal! 


\section{ABSTRACT OF THE DISSERTATION}

FICCIÓN DE RACIONALIDAD: LA MEMORIA COMO OPERADOR MÍTICO EN LAS ESTÉTICAS POLARES DE JORGE LUIS BORGES Y JOSÉ LEZAMA LIMA by

José R. Vilahomat

Florida International University, 2003

Miami, Florida

\section{Professor Santiago Juan-Navarro, Major Professor}

The aesthetic placement and period designation of Jorge Luis Borges (1899-1986) and José Lezama Lima (1910-1976) are complicated issues among critics. Borges is considered a predecessor of the Latin American literary "boom," but despite that taxonomy his work transcends that definition and provides a foundation for new trends, such as the "neobarroco" cultivated by Severo Sarduy. Lezama is considered part of the second wave of the "boom," but his work feeds, stylistically, from the Spanish baroque. At the same time, Lezama's daring treatment of homoeroticism and his system of images place him after the "boom" in a narrative style that is postmodern. This study undertakes a revision of external and internal issues, revealing the key fictive elements that characterize both writers. Through discourse analysis, a poetic system is formulated, which incorporates features of the "neobarroco," and postmodern narrative styles.

This dissertation uses a polar structure to analyze both poetic visions and finds that they are symmetrical. From this perspective, Borges and Lezama belong to the "core" of literature that centers its emphasis in the creation of a system versus other modes of writing in which mimetic function prevails. By doing this and by recycling 
world culture, they create postmodern myth: the new building material for Hispanic American literature.

There are a few studies that explore the works of Borges and Lezama within the context of Baroque aesthetics. This dissertation offers a comprehensive analysis that considers their poetic visions at large. Besides the difference in perspective, defined as macro-spatial in Borges and micro-spatial in Lezama, there are many similarities. Both writers question the cause and effect relationship and the use of metaphor. They share a redefinition of genre as well as a hedonistic approach to literature. This kinship in poetic vision is revealed through the polar method used for this study, which proposes a new form of aesthetic placement and period designation. 


\section{ÍNDICE}

CAPÍTULO

PÁGINA

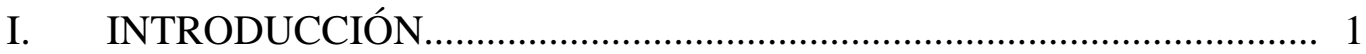

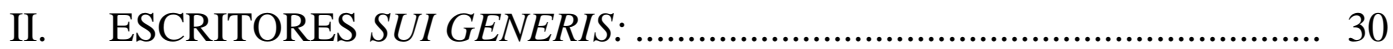

a. Relacion (humana) Borges/Lezama ................................................... 30

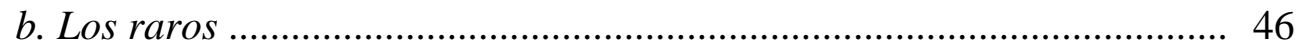

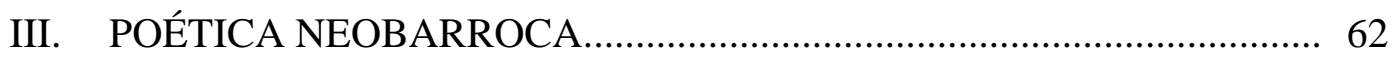

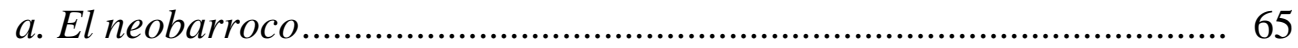

b. La perspectiva macroespacial y la yuxtaposición barroca..................... 101

c. La perspectiva microespacial y la metaforización barroca .................... 114

IV. FICCIÓN DE RACIONALIDAD ………………................................... 146

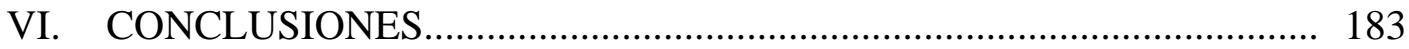

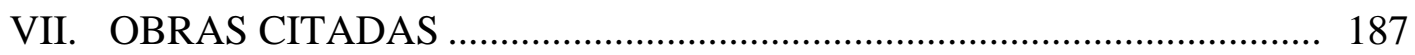

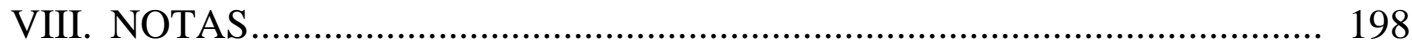


Me duermo en el tokonoma evaporo al otro que sigue caminando.

José Lezama Lima

Así mi vida es una fuga y todo lo pierdo

y todo es del olvido, o del otro.

No sé cuál de los dos escribe esta página.

Jorge Luis Borges

Ficción de racionalidad: La memoria como operador mítico en las estéticas polares de Jorge Luis Borges y José Lezama Lima.

O. - Introducción

El objetivo de esta tesis es demostrar el vínculo entre la poética de Jorge Luis Borges y la de José Lezama Lima. El estudio propone un modelo polar donde Borges se caracteriza por la perspectiva macroespacial y Lezama por una perspectiva microespacial. Si pensamos en una esfera, Borges estaría en un polo y Lezama en el polo opuesto. De manera que en cuanto a focalización, las estéticas serían diferentes. Si por el contrario, miramos la esfera desde el eje o punto superior, nos quedaríamos con un disco, donde Borges y Lezama estarían en un centro (core), en oposición a la periferia de la circunferencia. Esta periferia correspondería a la literatura realista, caracterizada por signos lingüísticos estables y referentes inmediatos. De manera que en cuanto a mimesis las estéticas de Borges y Lezama serían iguales. En este estudio el modelo polar contiene lo idéntico y lo opuesto.

Los elementos comunes a esta polaridad son el uso de la racionalidad y la memoria, como fundamentos de la ficción, y la creación de un sistema poético autoconsistente y metafictivo. La obra de estos autores pertenece a estructuras profundas del lenguaje donde ocurre la generación metafórica y mitológica. Borges y Lezama 
contraponen una mitología mental o sico-gráfica a la estética del realismo y a la filosofía de lo material. ${ }^{1}$ La originalidad de este estudio radica en la presentación de ambas estéticas desde un modelo común. Existen unos contados trabajos que vinculan a estos dos escritores, fundamentalmente en su relación con el barroco, pero en general la crítica se ha encargado de Borges y Lezama de manera independiente. ${ }^{2}$

Es obvio que Borges y Lezama compartieron un período histórico en la literatura, e incluso resulta interesante que el único libro de relatos de Lezama se concebía en la misma fecha en que el escritor argentino escribía Ficciones. Pero las confluencias entre ellos tiene un carácter más profundo que no se da a nivel de intertextualidades nacidas de lecturas recíprocas o imitaciones. La semejanza poética en este caso está generada por claves semióticas que produjeron fenómenos intelectuales afines. Ocurre aquí algo parecido a lo que Borges prefigura en la escritura del Quijote de Pierre Menard, sólo que a nivel poético, no textual, por supuesto.

Es sintomático que la relación de estos autores con el Boom es, cuanto menos, problemática. Ambos fueron entendidos a cabalidad sólo a posteriori y sumados o comparados con la tendencia dominante por la obligada proporción. En mi tesis llevo a cabo un estudio comparativo que los une sobre criterios estético-filosóficos, vinculados a la poética y no a la división regional o a la periodización abordadas con mayor insistencia hasta la fecha. Sigo, más bien, un derrotero afín a la posición de Claudio Guillén respecto a "la noción de período" (124). Espero aportar una perspectiva sugerente, que se una a los excelentes textos críticos que me han permitido entender mejor tanto los círculos del uno, como las tangencias del otro. 
Inicialmente, el trabajo surgió a partir de una intuición al comparar a ambos escritores en cuanto a su distanciamiento respecto a la corriente materialista de la época y al rechazo a incorporar la inmediatez en sus obras. Posteriormente se fueron uniendo otros elementos a esta primera intuición. Revisando la estructura de los relatos, las características de los poemas y las novelas de Lezama, así como los ensayos de Borges, encontré relación en sus modos de acercarse al hecho artístico y de tratar los géneros literarios. El estilo de ensayo relato, la novela poema, el poema como silogismo fueron rasgos comunes distintivos.

Luego vino la revisión de fuentes literarias y la correlación de intertextualidades. Comprobé que las fuentes que nutren el arsenal intelectual de Borges y Lezama convergen en tendencias similares como veremos posteriormente. Borges y Lezama fueron consistentes durante sus vidas en su gusto por la cultura helenística y por la escritura de los clásicos. También comparten una afinidad por la Escolástica y el Barroco. Es conocida la revisión que ambos realizaron de Cervantes, Quevedo, Góngora, Gracián y otros escritores u obras del periodo. Estudios o ideas sobre Sigmund Freud y Carl Gustav Jung son igualmente parte importante de las fuentes de estos escritores. Y por último, a esta larga lista de afinidades, hay que sumar un repertorio compartido de filósofos y tradiciones literarias occidentales y orientales. Todo esto sin dejar fuera las omisiones comunes sobre parte de sus contemporáneos; es decir, las fuentes intencionalmente ignoradas.

En las estéticas de Borges y Lezama se comparte la idea de una conciencia universal, un arquetipo o un panteísmo ideológico que nos produce esa sensación de estar vigilados en nuestras obras; de escribir bajo el influjo de un código secreto, o de ser la 
continuación de un plan vasto. Esta cosmovisión, a su vez, nutre una concepción analógica del devenir. En ambos escritores son fundacionales las disquisiciones sobre el concepto tiempo; ya se den éstas a través de la iteratividad histórica, o a partir de la relación causa-efecto. En el caso de Borges y Lezama estas preocupaciones nutren la ficción, se convierten en tema fictivo y reestructuran todo un sistema de expresión.

También, y por lo acabado de decir, es constante en los dos la búsqueda de la esencia y origen de la creatividad poética en referencia al registro total de la lengua. En ambos escritores se percibe un interés constante por la evaluación de las metáforas usadas por diferentes autores y culturas. En este sentido hay un especial interés por literaturas antiguas o culturas "primitivas", donde dicho elemento tiene un carácter prístino. Tal preocupación la refleja Borges en su ensayo "Las kenningar" aparecido en

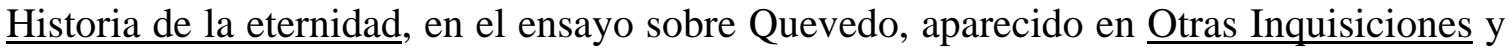
en otros de sus ensayos sobre el barroco y la literatura universal. Lezama muestra esta preocupación por el origen y la evolución metafórica en Las eras imaginarias, La expresión americana y en otros textos críticos y artísticos.

El interés por la génesis de la imagen hace confluir a ambos autores en las lecturas de Giambattista Vico, Góngora y Gracián. ${ }^{4}$ A su vez, la búsqueda de una nueva estética los lleva a visitar formas de pensamiento afines a la fenomenología, a la escolástica, a los trabajos de Espinosa, Berkeley, Spengler y Schopenhauer. En un estudio sobre Sarduy y Borges titulado "Borges a Cobra es barroco exégesis," Suzanne Jill Levine asevera que "para Sarduy, Lezama y Borges no sólo renuevan la lógica de los escolásticos del siglo XIII, sino también el 'saber total' de los enciclopedistas" (91). En esta indagación, Borges y Lezama se encuentran también en lecturas sobre el 
pensamiento oriental y en una revisión de la historia de la literatura. Por este afán totalizante a que Sarduy se refiere, pienso que en ambos yace implícita una nueva forma de la identidad latinoamericana que he denominado "esencialismo latinoamericano".

La actitud postulativa del escritor es otro aspecto común en las personalidades literarias que nos ocupan. Esto conlleva una conciencia trascendental y metagógica. Borges y Lezama se sintieron creadores de escuelas sin lugar a dudas, fundadores en gran medida, empeñados en establecer una obra continuable, una obra cepa. Cintio Vitier, en su antológico estudio sobre Lezama "La poesía de Lezama Lima y el intento de una teleología insular," expresa: "Hubo siempre en él una vocación de constructor, de fundador, una apetencia de coralidad" (48). A su vez, Jaime Alazraki ha expresado sobre Borges un concepto originario: "For Argentines, first, and for Latin Americans at large afterwards, Borges has become a sort of father figure: the progenitor of a language out of which, like from a seed, contemporary Spanish-American fiction evolved and reached maturity" (Critical Essays on Jorge Luis Borges 7). La actitud de Borges de no leer a sus contemporáneos (7) refuerza esta idea.

Tanto Borges como Lezama se enorgullecen de tener en sus familias ancestros militares. En el caso de Borges están su abuelo, el Coronel Borges, y su bisabuelo materno Coronel Isidoro Suárez, que en 1824 con sólo veinticuatro años de edad, "led a famous charge of Peruvian and Colombian cavalry, which turned the tide of the battle of Junín, in Peru [sic]" (Alazraki, Critical Essays 24). Es evidente el orgullo que Borges refleja ante los hechos heroicos de sus ancestros, y lo ha expresado en innumerables entrevistas. El relato "El sur" es uno de esos textos donde se trata el tema del honor y la virtud. "El sur" termina con un acendrado tono épico: "Dahlman empuña con firmeza el 
cuchillo, que acaso no sabrá manejar, y sale a la llanura" (Borges, Obras completas 1:529). Respecto al Coronel Borges, el autor comenta con orgullo: "In 1874, during one of our civil wars, my grandfather, Colonel Borges, met his death. [...] he rode out slowly on horseback, wearing a white poncho and followed by ten or twelve of his men, toward the enemy lines, where he was struck by two Remington bullets" (Alazraki, $\underline{\text { Critical }}$ Esays 22).

Lezama nació en medio del ambiente militar. Al respecto, comenta Armando Álvarez Bravo: "Coincide el nacimiento del poeta con el traslado de la familia a la Fortaleza de la Cabaña y el nombramiento del padre como director de la academia Militar del Morro" (11). El crítico comenta cómo Lezama vivió un mundo de disciplina militar y encuentros con el mundo de las armas. Posteriormente nos informa de la pérdida temprana de su padre, la cual fue un cambio drástico en su infancia: "Con motivo de la Primera Guerra Mundial, su padre se ofrece como voluntario para servir en las tropas aliadas y se dirige a Fort Barrancas, Pensacola, a prepararse. Allí, el 19 de enero de 1919, encuentra su muerte" (11). El campamento de Fort Barrancas aparecerá después en la novela Paradiso (Lezama, Paradiso 279).

Lezama encuentra, según Armando Álvarez Bravo "una realidad ajena al tiempo y a la circunstancia" en la literatura (12). Lezama tiene una visión de la vida militar, algo diferente a la de Borges, quizás por haberla conocido tan de cerca, y por el impacto emocional asociado a la perdida del padre. Como nos dice Eloísa Lezama Lima: "La sorpresiva muerte de nuestro padre fue decisiva en su niñez. [. . . Es Esa muerte constituye uno de los capítulos más patéticos de Paradiso" (Introducción 18). También en Paradiso encontramos líneas que nos recuerdan las referencias de Borges a su ascendencia: "El 
Coronel apretó más aún sus finos labios que revelaban su ascendencia inglesa por línea materna" (117). Existen otros momentos y textos donde el ancestro militar, como lo he denominado a modo de homogeneización, aparece con implicaciones épicas.

Aun considerando la diferencia entre uno y el otro, en mi opinión, la actitud postulativa a que he hecho referencia y el afán fundacional, se imbrican con la impronta que deja el ancestro militar en los textos de ambos escritores. Esa nostalgia por un pasado glorioso y la posición de hombres de letras que admiran una actividad que quizás no se atrevan a realizar, acentúan en sus ficciones un regusto por la épica. Una épica entre metaliteraria y nacionalista que se intelectualiza y da origen a un texto híbrido de un criollismo mítico. De esta manera, el referente local se confunde con el archivo de memoria, llegándose en ambos casos a una épica universal, a partir de lo particular intelectualizado.

Por la experiencia libresca y total, por el afán de crear un nuevo sistema de expresión que incluyera la relación del hombre con el universo, Borges y Lezama operan en todo el plasma literario como esas aguas profundas que arrastran el sentido y la dirección histórica a partir de la experiencia suma. Son una matriz generadora de la literatura donde no se dan los marcadores textuales a la usanza, sino las esencias teóricas en forma de una ficción racional de posibilidades infinitas, a la que Lezama denominó Potens y Borges asoció a los "arquetipo". $\mathrm{Al}$ respecto de esa erudición totalizante en Lezama, Roberto Fernández Retamar comenta: "Poseyó una información múltiple y una manera muy americana de incorporar la cultura universal, en una línea, aunque propia, cercana a las de un Alfonso Reyes o un Borges" (123). Por su lado, Carlos Fuentes dijo sobre Borges: "En la literatura de ficción, es Jorge Luis Borges quien rescata este 
derecho para crear, a su vez, una narrativa mítica" y más adelante añade: "Borges, además, se enfrenta a la totalidad de la lengua castellana con sus carencias y por allí, con su relatividad" (25-26).

Es ahí, en el plan vasto, donde la afinidad se me reveló con vehemencia. El interés de ambos escritores por crear una mitología para nuestras letras que, además, las conecta con el pasado y permite su proyección futura. Tal resultado, si no intención, coincide con la de los escritores clásicos griegos que crearon un sistema cerrado y autoconsistente bajo la sombra de La Ilíada y La Odisea. En Borges y Lezama se da la presencia de esa cosmovisión poética resultado del cúmulo de la civilización occidental. Es una integridad buscada a partir de la sistematización, donde los condimentos son la filosofía, la estética y la praxis; éstos son incorporados, luego, a un todo absoluto. Por eso, en el autor de "Muerte de Narciso" así como en el de El Aleph, huelgan los marcadores temporales o espaciales; se descarnan los textos hasta llegar a la proposición filosófica o al algoritmo elíptico, que es el mensaje ulterior y trascendente.

Ese estilo de construcción unas veces toma estructura simétrica (Alazraki, Critical Essays 10) y otras, formas arquitectónicas y de combinaciones geométricas como demuestra Tanner: "It is the constructional power of the human mind that moves and amazes Borges. His stories are full of the strangest architecture-the Library of Babel, the City of the Inmortals, the Garden of Forking Paths [. . .]." (165). Por estas combinaciones o arquitecturas se despliega un algoritmo u oximoron que refuerza la idea de unicidad universal entre la literatura y la realidad. Otros relatos donde Borges utiliza este diseño son: "El inmortal", mucho más arquitectónico y "Pierre Menard, autor del Quijote," donde prima la propuesta oximorónica. En "La trama" Borges nos da una clave de su 
gusto por estos recursos aunque los ponga en manos del destino: "Al destino le agradan las repeticiones, las variantes, las simetrías" (Obras completas 2:171).

El narrador de los relatos de Borges no se nos presenta como el creador del texto, sino como un mediador que rescribe o rescata piezas de algún archivo inmanente, pero velado a nuestra capacidad intelectiva. El autor nos demuestra así que la literatura con su lógica discursiva desvela la realidad. Se desprende de ahí la importancia del arte, parece enseñarnos Borges. Pero a la vez, al ir llevados a través del argumento por una demostración "lógica" (casi detectivesca o científica), nos sentimos también parte del proceso de descubrimiento, puesto que ambos, narrador y lector implícito, se encuentran a la misma distancia de ese archivo inmanente que pertenece a la cultura. La escritura metaliteraria de Borges nos pone a todos a la misma distancia respecto al tema del texto.

En ese plan preconcebido nos parece que el narrador descubre el arquetipo, que ha tratado de prefigurarlo geométricamente antes de plasmarlo en la escritura. Por eso es necesario aceptar sus premisas iniciales para luego disfrutar el juego coherente y analógico de su racionalidad. Este juego a veces concluye con la propia negación del postulado inicial. En otras palabras, la cosmovisión y la intención poética existen a priori y usan del relato para expresar su lógica.

No es éste el caso de otros escritores donde el texto se resuelve linealmente o el lenguaje arma el propio argumento. En este sentido, mi análisis tiene una dirección opuesta a la explicación de Carlos Fuentes, donde "el paso del documento de denuncia a la síntesis crítica de la sociedad [. . .] no hubiese sido posible sin este hecho central, constitutivo, de la prosa borgeana" (26). Ese meollo "constitutivo," ese "carbunclo" lezamiano sale de otras vertientes y llega a diferentes resultados. En los autores que me 
ocupan no hablo de novela de lenguaje, hablo de la reconstrucción de una memoria mítica, de procesos mentales que apuntan a la condensación de imágenes mediante saltos bruscos, y muchas veces inconexos en el devenir sígnico. Esta construcción mítica no necesariamente evoluciona a una "síntesis crítica" en escritores posteriores, sino que irradia en todas direcciones. Piénsese, a este respecto, en la obra sarduyana como herencia de los dos escritores que nos ocupan.

Al hablar de preconstrucciones geométricas, debemos tener en cuenta la diferencia en cuanto a enfoque entre Borges y Lezama. El primero usa un enfoque macroespacial, mientras que el segundo prefiere la focalización microespacial. Aún así, Lezama también construye a partir de su sistema poético. Los relatos "El patio morado," "El guardián inicia el combate circular," son ejemplos de esta preconstrucción donde el lector es condicionado a entender un nuevo sistema y a aceptar leyes de un mundo creado, también a priori, por el autor. La propia novela Paradiso está preconstruida desde la concepción de una verdad-imagen arquetípica.

Esta condición ha llevado a críticos y escritores a considerar Paradiso un poema. Julio Cortázar se adelantó en ver estos asentamientos estéticos cuando dijo: “¿Una novela Paradiso? [. . .] Paradiso se aparta del concepto usual de novela, [. . .] de alguna manera todos y cada uno de los personajes que están vistos en esencia mucho más que en presencia, son arquetipos antes que tipos" (136). Lo que sucede, en mi opinión, es que la estructura "imaginal" es tan fuerte que domina la estructura narrativa. El argumento y sus marcadores son la justificación de una propuesta metafórica. El propio Lezama dice: "Construyo un esqueleto imaginario y voy añadiendo, voy quitando, con el propósito de 
comprobar el secreto de su resistencia pétrea" (Tomado de Eloisa Lezama Lima, Introducción 51). ${ }^{6}$

Esa "resistencia pétrea," será el zócalo literario sobre el cual se asienta la literatura de la humanidad como arquetipo. La estructura arquitectónica es menuda en Lezama a manera de brocal, llena de pequeños conceptos que arman metafóricamente la complejidad barroca del texto. Este barroco metafórico procede de la perspectiva microespacial. En cambio, la estructura arquitectónica en Borges se despliega en elementos geométricos explícitos. Mediante las combinaciones de esas simetrías geométricas, de esas variables matemáticas que se yuxtaponen, también se obtiene un texto de complejidad barroca. Lo cierto es que ambos huyen de la narración descriptiva y anecdótica consecuente, para dar una propuesta epistemológica. Es como si intentaran crear un sistema gnoseológico, a partir de la literatura, que permita entender las relaciones universales, a través de nuevas lógicas.

Yo planteo que Borges y Lezama construyen una realidad literaria. Instauran un mito que proviene de la literatura y se dirige a ésta; lo cual, para muchos, es representado por el término metaliteratura y con el que, en términos generales, estoy de acuerdo. Luego, desde dicho mito parten muchas obras posteriores. Aquí se da la capacidad generadora o fundacional de ambos. A este aspecto se refiere la pasada cita de Carlos Fuentes sobre el "hecho central, constitutivo, de la prosa borgeana" (26). Pero en mi análisis veo la relación literatura-realidad en una dirección. Si para Carlos Fuentes la literatura debe evolucionar hacia una operatividad, en el caso de Borges y Lezama yo opino que se mantiene en una meta-operatividad. Todo el pragmatismo literario se centra en una función autoestética y mitofictiva en este caso. La escritura y el arte tienen para 
ellos un sentido ecuménico y cristalizador en la cultura. Sólo de esta manera mediatizada, y a través de las coagulaciones míticas en la cultura, se puede hablar de operatividad en Borges y Lezama.

Gustavo Pellón ofrece un punto medio entre arte y sociedad que me resulta mucho más convincente, y a la vez, cercano, a la estética de Borges y Lezama. La mediatización que implican los conceptos naturaleza y cultura están más cerca del trabajo que ambos autores, en cuestión, realizan en términos de "mitologizar" la realidad y recrear la cultura total. El crítico ve esta relación como un proceso de síntesis entre la cultura y la literatura en Lezama:

Perhaps the most disconcerting feature of Lezama's work is a practice of reading and writing that flies in the face of the Western literary tradition by dissolving the fundamental dichotomy between nature and culture. Mimetic and antimimetic poetics equally build their edifices on the distinction between art and nature despite their differences regarding the character of that relationship. (47)

En este caso el modelo de elipsis barroca en el cual Borges y Lezama se mantienen en los recursos de parodia metaliteraria resulta un modelo efectivo. La síntesis entre literatura y cultura en este estudio se entiende sólo desde la literatura y donde la realidad aparece alegorizada.

Este método auto-referencial del que se valen ambos autores, conecta los niveles profundos del texto con la literatura universal. Tal conexión tiene lugar a través de los sistemas arquetípicos metafóricos, como responde Lezama en una entrevista a Armando Álvarez Bravo: "Las conexiones de la metáfora son progresivas e infinitas. El cubrefuego 
que la imagen forma sobre la sustantividad poética es unitivo y fijo como una estrella" (Álvarez 21). En la siguiente pregunta de la misma entrevista, Lezama completa esta interpretación de la literatura como un todo interconectado en el plasma metafórico:

Cuando me fui acercando a mi madurez intelectual, yo, que como casi todos los poetas he sido hombre de variada y voluptuosa lectura y seguía la tradición de La Fontaine (sic) que postulaba que el poeta es el amateur de tout les choses, le poliphile, fui comprendiendo que por ese aventurado juego irreversible de la metáfora y la imagen, esa aparente dispersión de lecturas era una devoradora ansia de integración en la unidad, en el espejo, en el agua fluyente y detenida. Un día, pensaba en grandes periodos de la historia que no habían tenido ni grandes ni poderosos poetas y que, sin embargo, eran grandes épocas para el reinado de la poesía. [. . .] Eso me llevó a estudiar lo que llamo las eras imaginarias, [. . . ] que estimo son lo más significativo de mi obra. (21)

Las eras imaginarias conectan periodos históricos con imágenes, estableciendo así un vínculo entre imaginación e historia; pero donde la segunda está supeditada a la primera. La escritura de Borges y Lezama, establece un diálogo intelectual con la imagen universal, con esa realidad metaliteraria que ya es parte de nuestra inseparable (¿indefinible?) conciencia. Esta idea es claramente recreada por Borges en La cifra en los poemas "Beppo" (마as completas 3:295), "Blake” (308), "Corre o ser” (323).

Toda mitología, toda convención se da cita en ese texto altamente metaforizado y lacónico de inmediatez que se autodefine. Dicha escritura basal establece una conexión geo-gráfica y cultural con el mundo, a partir de una proyección sico-gráfica. Los 
laberintos, las galerías, los círculos, los espejos, el tokonoma, el aleph, el ajedrez, la flecha, el caracol, la estrella, el carbunclo, el ojo paleolítico del elefante, las volutas en que se enrolla la propuesta, son "proyecciones sicológicas," metaforizaciones directas de los espacios mentales a los que alude el texto. De nuevo, Borges procede con una perspectiva centrípeta que va de afuera hacia adentro. Es como si, imitando el sentido de la arquitectura clásica griega, atrapará el espacio a través geometrías simétricas. Para luego presentarnos esas geometrías como orden del universo. Son más comunes en él las galerías, los laberintos, los espejos, para llegar de ahí al aleph. Se llega a un centro que puede desvelar una respuesta o enfrentarnos a la imposibilidad de obtenerla.

Si pensamos en un cono geométrico invertido, Borges estaría situado en la abertura o base y desde esa macroespacialidad llegaría al centro. Borges, de alguna manera, replica las dimensiones y proporciones geométricas del universo que restringen y contienen al ser como en un laberinto. A partir de eso, no le queda otra opción de aprehensión de cierta verdad que la de un punto (Aleph), en donde ese cono deposite toda su esencia. Ese centro sería una especie de asidero donde todas las realidades converjan; donde se dé toda la complejidad concentrada. Sería el punto desde el cual se ven todas las páginas del único libro escrito por la humanidad, o los múltiples tiempos en que conviven los personajes a que se refiere Stephen Albert en "El jardín de senderos que se bifurcan" (Obras completas 1:479).

De esta manera entiendo que la escritura de Borges parte desde una complejidad a un proceso de simplificación, aunque es cierto que ocurren movimientos pendulares en medio de este proceso. Tal vez se pueda afirmar que esta evolución ocurre en ontogénesis, así como en filogénesis. La simplificación, de la que ha hablado Borges en 
su escritura de madurez, guarda relación con la simplificación al final de cada relato como estilo interno. Los relatos de Borges generalmente concluyen con una sorpresiva síntesis que nos alivia del barroco del entramado argumental. No digo que este final se presente como solución; sino que deja los términos contradictorios despejados. En otras palabras, el cuento llega a simplificar ese fragmento dónde residen las alternativas que se contradicen. Cito de Obras completas: "Ireneo Funes murió en 1889, de una congestión pulmonar" ("Funes el memorioso" 1:490); "Yo he denunciado al hombre que me amparó: yo soy Vincent Moon. Ahora desprécieme" ("La forma de la espada" 1:495); "Yo mismo estoy falseando y perdiendo, bajo la trágica erosión de los años, los rasgos de Beatriz" ("El Aleph" 1:627). Aquí se ve esa frase que mediante el proceso de la lógica discursiva nos arroja la contradicción final simplificada.

En Lezama la realidad se aprehende mediante el ojo del elefante (Poesía 393), el tokonoma, el caracol, el carbunclo y desde ahí se ve el universo. La visión de Lezama comienza por el punto, escuchando al caracol, observando la hoja que trae el otoño como en el poema "Lo inaudible" (Poesía completa 437). El universo le es entregado a Lezama a través de un murmullo o un rumor (Poesía 99). En palabras de Cintio Vitier, la "libertad imaginativa" de Lezama "no es nunca una disipación excéntrica (fuera del centro) ni una simple apertura a las fuerzas del subconsciente onírico, sino un encarnizado mirar la fijeza vertiginosa que lo mira ("La poesía” 56. Paréntesis de Cintio Vitier). Aprovechando de nuevo la utilidad del cono como metáfora visual, diríamos que Lezama se sitúa primariamente en el extremo estrecho del cono, en su punto material y de ahí propone su versión de realidad. Lezama parte de la simplicidad y desde ahí van 
conglomerando, sumando, entretejiendo la infinitas posibilidades sígnicas. Desde ese centro se genera centrífugamente la realidad.

Si la perspectiva borgeana replica las líneas rectas y precisas de la arquitectura clásica, que intentan definir el espacio que encierran, la perspectiva de Lezama replicaría la arquitectura India que se abre al infinito, que se expone a lo desconocido. Tomando de nuevo el modelo esférico inicial que nos apoya en la estructura polar de la tesis, y comparándolo ahora con los polos magnéticos de la tierra (o con los polos de un imán cualquiera), tenemos que Borges sería el polo sur, al cual entran las líneas de fuerza magnética y Lezama el polo norte, del cual parten las líneas de fuerza. La penetración microespacial de Lezama, su adentramiento en el micromundo (Tokonoma) es un paso liminal para desaparecer, evaporarse y ser en otra latitud infinita (Poesía 396). En cambio, la focalización macroespacial de Borges es una expansión controlada, que pretende encerrar el universo logrado (explicado) por su proceso intelectivo, en un punto material: el aleph.

Individuos, indivisibles al fin, como sugieren los escolásticos, pudiéramos pensar que Borges imita en su perspectiva poética su circunstancia multicultural. Borges se encuentra a caballo, al fin, entre dos culturas, la occidental europea, saliente de su declarada sangre sajona y la criolla argentina, ambas vigiladas mutuamente como en el caso de Juan Dahlmann en "El Sur" (Obras completas 1:524). Como apunta Jaime Alazraki: "[. . .] in North America he was read either as an European or as a North American. He was so familiar with both literary traditions that his readers there thought of him as a fellow countryman" (Critical Essays 7). Esta doble perspectiva en Borges hace que su lector implícito esté en los dos polos culturales al mismo tiempo. Es ahí a 
donde va dirigida la perspectiva macroespacial de Borges, y de donde proviene, humanísticamente hablando. Una perspectiva, que como recurso fictivo, procede al igual que la técnica policial y avanza de afuera hacia adentro, buscando el punto material.

Lezama, por otro lado, es compatible en su perspectiva microespacial con su criollismo secular y su enclaustramiento físico. Los laberintos y las geometrías de Lezama se reducen, sólo espacialmente, a su entorno. Pero su explosión imaginativa sobrecompensa ese microespacio con la densidad de sus textos. Analizando el poema "Se desprendió" del libro fragmentos a su imán, Luis Antonio de Villena comenta: "Es como si sobre tal objeto se aplicase una muy potente lupa y ello provocase una sucesión encadenada de imágenes" (67). De manera que el macroespacio en Borges y el microespacio en Lezama actúan aquí como el macromundo y el micromundo, con similitudes e interacciones imprescindibles para entender el sistema, ya sea del universo o de la literatura, al cual nos encaminamos.

En suma, el debate sobre la validez de emprender un estudio que suponga a Borges y Lezama afines en poéticas y derroteros intelectuales conlleva vencer ciertos obstáculos de forma; pero arroja indudables resultados de contenido. No cabe duda de que el argentino y el cubano fueron polos opuestos en cierto sentido. Al decir de Julio Ortega, Borges y Lezama fueron "polares pero complementarios" ("Lezama” 248). En mi opinión, Borges y Lezama fueron polares en muchos sentidos: geográficamente, Argentina/Cuba; dimensionalmente, La Pampa/la isla; perceptualmente, el macroespacio estético/el microespacio estético; ${ }^{7}$ epistemológicamente, escepticismo/panteísmo; estilísticamente, barroco por secuencia (juxtaposición barroca)/barroco por imágenes (metaforización barroca). 
Pero como polos, comparten también las características comunes del concepto, similarmente a los del planeta que comparten su blanco, su frío y sus simetrías a pesar de la distancia. Borges y Lezama comparten axiologías similares. Están en un mismo eje definido por la universalidad de la imagen, donde la memoria de la humanidad se preserva por medio de la metáfora; definido también por el esencialismo latinoamericano; ${ }^{8}$ el idealismo perceptual y la ficción de racionalidad, conceptos que desarrollaremos más adelante. Al respecto de esto que he llamado esencialismo latinoamericano, dice Gustavo Pellón sobre Lezama: “There are two reasons for this idiosyncratic attitude toward culture: one is related to Lezama's concept of poetic creation, and the other is rooted in his concept of Americanness" (47). La americanidad para Lezama se expresa mediante la originalidad de su literatura, de la creación de su propia epopeya que se asienta, a su vez, en la autoctonía de su telos.

En conjunto, sendas literaturas crean jalones (polos) a través de sus cuerpos poético-filosóficos, rescatan una mitología para la lengua y se abren a lo universal a través del signo lingüístico. Es la expansión mental del código a partir de la posición polar y fija de las "bibliotecas." Borges y Lezama también comparten la indefinición del género literario y la preocupación por la renovación artística. Tienen un criterio sui géneris sobre las obras clásicas que diverge del canon establecido en la mayoría de los casos. Indagaron sobre aspectos recónditos de su cultura, como las misiones jesuitas en América, entre otros. Plasman el orgullo por el ancestro militar como forma de asentar la tradición. Se cuestionan el materialismo y la lógica aristotélica. Incluso, yendo al estilo específico dentro de los textos y llevados por el gusto de las mitologías nórdicas, árabes, medievales, o de la alquimia china, vemos que sus relatos comienzan con el dato cultural 
recóndito, intencionadamente presentado como información trivial. A su vez, evitan el costumbrismo o la inmediatez narrativa a no ser que ésta derive en sentencia o generalización. Todo texto en estos autores se viste de leyenda o mito al tiempo que se enuncia. En estas coincidencias hemos basado los razonamientos del estudio que nos ocupa.

Respecto a la comparación con la literatura del boom, debo decir que ciertamente muchas de las mencionadas preocupaciones formales y de renovación eran parte de una corriente de época. La búsqueda de fórmulas nacionalistas o criollistas es una manera de compensación contra el espíritu colonial. Sentimiento (sico)lógico en esa etapa de definición de la identidad americana. Lo compartieron Carpentier, Arguedas, García Márquez, Cortázar, Juan Rulfo, ya incluso en una dimensión continental más que nacional. La lista entre los que buscaban explicarse los orígenes, revisar la historia y encontrar una expresión para las letras del continente sería interminable. Borges y Lezama lo abordaron estéticamente, de forma diferente al resto y similar entre sí. Faltó en ellos el lema del texto como arma de combate. No entendieron la literatura como un objeto de utilidad inmediata, quizás por estar ambos convencidos de la futilidad y envejecimiento de las corrientes y empresas causadas por circunstancias históricas particulares. Por otro lado, estos autores estuvieron muy conscientes y preocupados por la revolución formal del lenguaje, y sobre todo, por la evolución de la metáfora.

Fue un encomio mucho más abstracto el de los autores en cuestión en este estudio. Las preocupaciones tanto de Borges como de Lezama se centraban en temas estéticos, metaliterarios, concentrados en la herramienta metafórica que explica la realidad; en el proceso de adquisición de ésta y en la creación de una mitopoética. Sus 
enfoques no fueron antropológicos o primitivistas al estilo de Carpentier o de Asturias, ni implican una mímesis telúrica local como los textos de García Márquez.

En una discusión sobre realismo mágico y primitivismo, Erik Camayd-Freixas habla de tres tendencias universalistas surgidas a partir de las vanguardias. La primera tendencia "buscó su universalidad en la sicología y en la condición humana" y en ella menciona a Macedonio Fernández, Roberto Arlt, Leopoldo Marechal y Ernesto Sábato entre otros. La segunda "desplegó su inquietud por la innovación formal" y en ella se menciona a Borges; y por último, hay una tercera tendencia denominada en el estudio "realismo mágico en el sentido etnológico" donde figuran Carpentier, Asturias, ("y más tarde”) Rulfo y García Márquez (10).

Según Erik Camayd-Freixas la obra de Borges entra en este debate como "tendencia formalista" "en pos de una poética renovadora del lenguaje narrativo" (10) y ciertamente acota que, aunque fue criticada por los partidarios de la literatura comprometida y autóctona, dicha tendencia "contribuyó más que ninguna otra tendencia a sacar a la ficción latinoamericana del provincianismo, y a superar su realismo vetusto sin recurrir a la afectación lírica ni al lente distorcionante de personajes psicóticos" (10). Esta división nos separa a Borges, no sólo como precursor, de la mayoría de los escritores del boom, a la vez que enfatiza la posición proestética del autor. Seymour Menton expresa una opinión semejante a la anterior y posteriormente un deslinde que nos interesa observar: "Jorge Luis Borges, más que nadie, ha promovido la reacción en contra del criollismo mediante sus cuentos filosóficos" (El cuento 340 ) y en la página siguiente agrega: 
Sin embargo, algunos críticos, sobre todo argentinos de la generación de David Viñas y otros más jóvenes, le han tachado de escapista y de reaccionario por lo que llaman su actitud despreocupada frente a los graves problemas nacionales y continentales. Toca preguntar si se le puede llamar escapista a un hombre que ha convertido el cuento en un género capaz de expresar conceptos filosóficos sobre la naturaleza del hombre, de la historia y de la realidad de todas las épocas. (341)

Una reivindicación de la obra de Borges y de Lezama en relación con las izquierdas y sus peculiares nacionalismos, está por hacerse, teniendo en cuenta las estructuras socioeconómicas actuales. Borges fue profundamente orgulloso de su estirpe y de su cultura y se dedicó profesional y exitosamente a encontrar una expresión genuina para las letras argentinas.

Lezama tuvo un rango más amplio de preocupaciones que Borges respecto a las artes. ${ }^{9} \mathrm{Su}$ conocimiento de las artes plásticas y la arquitectura está plasmado en $\underline{\mathrm{La}}$ expresión americana y recogido posteriormente en algunos textos de Fascinación de la memoria y La materia artizada; pero igualmente descree del comprometimiento y la utilidad del arte como lo entendían las vanguardias. Lezama, en una conferencia sobre literatura cubana, expresó lo siguiente sobre la literatura "útil":

A mi manera de ver, este utilitarismo es en el fondo una manifestación de lo que Schiller ha llamado el seudorromanticismo vitalista.

Voltaire tiene una frase muy significativa sobre Marivaux: "Conoce todos los senderos del corazón e ignora el camino grande". Pero Faguet se encarga de vengar a Marivaux de esa frase: "Allí donde nadie ha llegado, 
ni siquiera hay caminos". Es decir, hablan constantemente de reglas, de cánones, de métodos, pero realmente en el camino grande no existen ni siquiera esos caminos para llegar a las grandes expresiones de la cultura. (González Cruz 67)

Lezama y Borges supieron hallar sus grandes caminos y fueron fieles a sus convicciones. Sus sistemas poéticos se desarrollaron en medio de las vanguardias con originalidad y sin interferencias disgregantes.

La literatura estuvo en el centro de preocupaciones de las vanguardias. El ideal de reformas y revoluciones planteó problemas estéticos como la crisis de la novela y la función del arte; por un lado y por otro, los nuevos aportes en ciencia y humanidades arrojaron herramientas y perspectivas distintas. Cortázar descoyuntaba la estructura de la novela o relataba en segunda persona, a la vez que García Márquez instituía el realismo mágico, ya en un plan consolidado, como manera nueva de reflejar "otra" realidad. Esta estética se enfrentaba como variante al "objetivo" realismo socialista. De algún modo los escritores de la época compartían una u otra característica; pero pocos se encontraban en tantas como lo hicieron Borges y Lezama. Pocos insistieron tan profundamente en conceptualizaciones y métodos que "reciclaran" la cultura del mundo toda, para pasarla por el tamiz latinoamericano y crear una mitología propia. Ambos forman un conjunto singular, marcado muchas veces por afinidades negativas de no pertenencia, pero consistentes y compatibles como para conformar un modelo de análisis.

Dado que es éste un estudio sobre poética, la literatura activa que hemos escogido es variada. En cuanto a obras de ficción, la narrativa nos dará la posibilidad de un análisis textual para rastrear recursos temáticos, espacio-temporales, composicionales y fictivos 
en general. Estos aspectos son más visibles en la narrativa que en la poesía. Utilizaremos textos de Borges como Historia universal de la infamia, Ficciones, El Aleph y El libro de arena. En Lezama utilizaremos el libro de Relatos, cuyos cuentos se gestaron en su mayoría simultáneamente a Ficciones de Borges y las novelas Paradiso y Opiano Licario.

La ensayística nos ayudará a revisitar planteamientos filosóficos y a entender las preferencias estéticas de los autores; así como a entender la crítica a que dichos autores someten a los diferentes periodos de la creación literaria. Son básicos en Borges, El tamaño de mi esperanza, Discusión, Historia de la eternidad y Otras Inquisiciones, y en Lezama, Las eras imaginarias, Analecta del reloj, La expresión americana, $\underline{\text { Tratados en la }}$

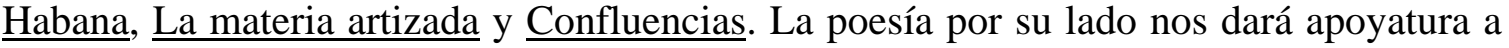
la filosofía y permitirá un adentramiento en la poética y nos ayudará a entender el proceso de síntesis metafórica en los autores. En Borges, utilizaremos Fervor de Buenos Aires, El hacedor, Elogio de la sombra, La rosa profunda y La cifra; y en Lezama, Muerte de Narciso, Enemigo rumor, La fijeza, Dador y Fragmentos a su imán. He preferido analizar textos de diferentes periodos en la vida de los escritores para comparar las tendencias y su constancia a lo largo de sus carreras literarias.

En cuanto al instrumental teórico, el presente trabajo implica una revisión actualizada de la crítica literaria en una aproximación casi ecléctica y de corte comparativo. Entre los métodos de análisis más conspicuos cuento con el análisis textual, las ideas sobre los arquetipos, tanto de Carl Gustav Jung como de Northop Frye, y la teoría de la recepción. También me valgo de cierta categorización estructuralista de corte marxista. Las teorías de la deconstrucción y la crítica del logocentrismo influyen una parte de mi tesis, por cuanto estos autores gestaron sus obras en la plena intuición de esas 
corrientes de revisión y revolución de perspectivas. Estas teorías, escuelas y sistemas de crítica estarán siempre auxiliando la tipología y el método de la estructura polar que conforma mi estudio.

Se puede ver el desarrollo de la literatura, desde la perspectiva actual, como un continuo que va desde el surrealismo, pasando por las vanguardias, hasta llegar al postmodernismo para lograr la expansión de visión, de géneros y de autores con que cuenta la sociedad presente. Las obras de Borges y Lezama impulsaron esta evolución. Éstas llegan tan lejos como a la teoría del caos y los fractales. Tanto la filosofía borgeano-lezamiana como las teorías físicas mencionadas nacen de la destrucción de la totalizante ciencia modernista y la desarticulación de la preeminencia de lo materialcontinuo. Las ideologías de Borges y Lezama están totalmente actualizadas y marchan en la literatura a la par de las corrientes de pensamiento más avanzadas y originales de la época. Estos autores, sin necesidad de recurrir a la ciencia ficción, prefiguran en sus sistemas de pensamiento algunas de las teorías científicas y humanísticas de hoy día.

Es cierto que los conceptos centro-periferia pueden ser aplicados aquí sólo parcialmente, en tanto se considere a América Latina periferia; sin embargo, Borges y Lezama no entrarían en otra periferia oral o intelectualmente marginal como novísimos o postmodernos. Borges y Lezama asomaron filosóficamente al post-modernismo. Ellos predispusieron la metáfora y el plasma estético a la nueva era y vieron a la idea y a la energía como nuevo orden del universo. Sin embargo, de la misma manera que se distanciaron de las vanguardias para encontrar sus voces propias, no cayeron en nuevas modas literarias efímeras. 
La idea de arquetipos en la cultura que nos indican caminos estéticos y nos sugieren imágenes es central en las poéticas de los autores en cuestión. El origen de esta idea se puede ir a buscar tan lejos como en las "formas puras" de Platón, pero un importante impulso de estructuración científica se halla en los estudios de Carl Gustav Jung y de Northrop Frye. Los arquetipos Jungianos están, a su vez, sugeridos por Sigmun Freud en "Creative Writers and Daydreaming" cuando el psicólogo plantea que: "The study of constructions of folk psychology such as these is far from being complete, but it is extremely probable that myths, for instance, are distorted vestiges of the wishful fantasies of whole nations, the secular dreams of youthful humanity" (655).

Carl Gustav Jung tipifica ciertos arquetipos y habla de "primordial images" (665). Con esta división explica, racionalmente, la idea del escritor que crea intuyendo, o dirigido por, fuerzas externas. Estos conceptos del inconsciente colectivo y arquetipos universales forman parte, sin duda, de la conciencia de la época (idea también arquetípica), y están relacionados con el surrealismo y las vangurdias que querían encontrar ese "deeply graven river-bed in the psyche" (Jung 665). Borges y Lezama desarrollaron una peculiar idea al respecto de estos conceptos. Y tiendo a pensar que no siguieron a un autor específico, por eso me veo obligado a mencionar el desarrollo vario de esta idea arquetípica. En algunos textos se ve cierta tendencia a los arquetipos jungianos, en otros, a los arquetipos de Northrop Frye, donde se relacionan épocas, o estadios de la humanidad con ciertas imágenes y, en menor medida, con géneros literarios.

Los arquetipos de Northop Frye también servirán para establecer una comparación entre ambas estéticas. La obra de Northop Frye, Anatomy of Criticism, nos 
servirá de base, aunque es pertinente aclarar que en Borges y Lezama los arquetipos tienen una fuerte carga gnoseológica y son además un recurso estético. La delimitación precisa de géneros literarios, a partir de arquetipos, desarrollada por el crítico canadiense y revisada minusiosamente por Tzvetan Todorov en The Fantastic (8), nos alejaría del tema en cuestión.

Borges y Lezama recrearon la arquetipificación como idea recurrente en la literatura en la década en que el crítico canadiense desarrollaba su teoría, pero en los primeros hay un pensamiento híbrido que incluye la interpretación de Jung y considera unos arquetipos un tanto metafísicos. Quizás el origen de la idea arquetípica sea el mismo, con la diferencia de finalidad entre un discurso científico, y otro fictivo. Posteriormente, en Las eras imaginarias, Lezama aborda una idea donde asocia periodos históricos, a etapas de evolución de la imagen, desde una perspectiva poética. Por su parte, Borges trata los arquetipos como una consciencia universal que nos dicta estructuras de pensamientos y afinidades que burlan el tiempo evolutivo en la cultura.

Buscando los vínculos incluso desde Sigmund Freud y Carl Gustav Jung, podemos inferir cierta conexión entre los arquetipos y el inconsciente humano en las obras de los autores que nos ocupan. Lezama asume en su sistema poético el concepto imago. Recordemos que éste era precisamente el título de una de las revistas fundadas por Sigmund Freud. La conexión no me parece gratuita. En Lezama el concepto es clave para entender la memoria social transmitida a través de la metáfora, primero, y luego, la propia imago se presenta como fuerza creante, generadora de la realidad.

La imago, esa fase en que el insecto se transforma en su versión alada, es el cruce del umbral o la liminalidad en la que se entra para abrirse a una libertad sin límites. Así 
mismo, la imago lezamiana significa el quantum de imagen poética: el eslabón infinitesimal de la génesis epistemológica, a partir del cual se da la explosión de la imagen generatriz de la realidad. Así la pondera el propio Lezama: "Pero a nuestro parecer la adquisición fundamental de Orígenes es el concepto de la imago como una fuerza tan creadora como la semilla" (Vitier, "La aventura de Orígenes" 331). Por otro lado el crítico Donald Shaw asevera que: "Con Licario llegamos al centro del sistema de pensamiento de Lezama, puesto que con Licario se inicia 'la participación de Cemí en la imagen, en la poesía y en el reino de los arquetipos"” (155).

En Las eras imaginarias Lezama realiza un extenso estudio explicando el arquetipo generatriz de cada era. "Los egipcios", "La biblioteca como dragón”, así como la metaforización de los colores en la alquimia china, son ejemplos de condensaciones metafóricas pasadas a la cultura y que operan como preservadores de ésta. ${ }^{10}$ Lezama también hace referencia al arquetipo en varios poemas y relatos. En Borges, por otro lado, el arquetipo está levitando en nuestras obras dictando el sentido de la historia. Funciona desde el inconsciente, como hemos sugerido, dictándonos los modos literarios y haciéndonos coincidir con previas elaboraciones quizás desconocidas por nosotros. Es la línea vertical que atraviesa toda la creación humana.

El autor se encarga de explicar esto vehementemente en relatos como "El sueño

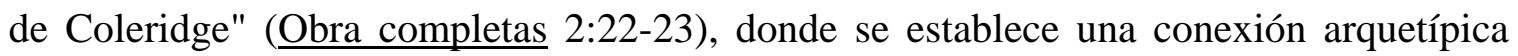
entre la construcción en piedra y la construcción en palabras, dada por el palacio de Kubla Khan y el poema de Coleridge. En el último párrafo del cuento Borges dice: "Acaso un arquetipo no revelado aún a los hombres, un objeto eterno [. . .] esté ingresando paulatinamente en el mundo; su primera manifestación fue el palacio; la 
segunda el poema. Quien los hubiera comparado habría visto que eran esencialmente iguales" (23). El libro La cifra está compuesto en casi su totalidad sobre la presencia de los arquetipos en nosotros. En tal sentido me parece obligado unificar el tema de los arquetipos, por cuanto ambos escritores los trabajan como materia fictiva, ya sea desde una creencia filosófica o desde el complejo escepticismo; pero estrechamente relacionados a la repetibilidad histórica y al tema de la relación causa y efecto.

Tanto Borges como Lezama juegan despiadadamente con el lector desde una posición de maestros. El humor intelectual, a veces mordaz, necesita de la agudeza del lector que en ocasiones no se percata de que es parte de la farsa. Pero el asunto va mucho más allá. Tanto uno como el otro entienden al ser humano como un producto de la información. Borges es consciente de que diferentes culturas han hecho lecturas dispares de los mismos textos clásicos y usa dicho "prejuicio" cultural como elemento de ficción. Lezama, al concebir la imagen como elemento fundador de la realidad y el pensamiento, le otorga al lector la calidad de re-creador de la imagen. La incredulidad sobre la información que nos entregan los sentidos de uno y la búsqueda de lo desconocido a partir de la imagen del otro, ponen al lector en la misma posición en la que se encuentran ellos con respecto a la realidad.

La teoría de la recepción es una herramienta clave para desentrañar estos mecanismos, que están a su vez, estrechamente vinculados a lo que denomino ficción de racionalidad. Es cierto que Borges es explícito y diáfano en este propósito y que Lezama lo hace de manera velada, a través de una alegoría que se debe desentrañar. La diferencia es un asunto de tiempo. Borges comparte el hallazgo con el lector en el instante de la lectura, cumpliendo una función hedónica y Lezama lo sugiere para que ambos, lector y 
autor, lo compartan pausadamente en la meditación posterior, como en una especie de círculo "délfico", cumpliendo una función estoica.

Después de esta introducción comenzamos el estudio con un análisis casi ecléctico. La propia esencia del trabajo lo hace caer dentro de tal eclecticismo. El objetivo es definir esa poética polar, en la que inscribo los textos de Borges y Lezama, lo cual nos obliga a un estudio comparativo que abarca muchos elementos y momentos de ambas escrituras. No pretendo simplificar el trabajo al punto de borrar las obvias diferencias entre uno y el otro. Pero sí pienso que definir una estética, basada en un modelo polar, desde la comparación de estos dos escritores, resulta más útil a la crítica literaria, que mantener al argentino y al cubano en ese limbo donde ambos aparecen como figuras conspicuas, a la vez que como fenómenos singulares. Nos conviene ahora indagar en las reales interacciones humanas y/o literarias en ambos autores, para definir después si las afinidades estéticas están basadas en influencias directas o en corrientes profundas de pensamientos, como es mi intención demostrar. 


\section{1. - Escritores sui géneris}

\section{a. - Relación (humana) Borges-Lezama}

El oximoron que constituye el título de esta sección compite con la esencia del trabajo y con los modos de los autores que aborda. En otras palabras, he usado la herramienta transformada y creada por el medio al cual se enfrenta. Lo cierto es que la relación humana entre Borges y Lezama nunca existió y cualquier vínculo fue siempre mediado por los admiradores de ambos. Insisto empero, en que hubo un respeto y un seguimiento de los derroteros intelectuales, más visible en Lezama que en Borges, pero presente en ambos. En ocasiones, el mencionado vínculo se realizó indirectamente a través de artículos o documentos sobre los autores, publicados en las revistas a cargo de Borges o Lezama, respectivamente.

Otros comentarios se pueden encontrar en las entrevistas con citas o implicaciones de un autor sobre otro. Ciertos viajes de Virgilio Piñera a Argentina y sus colaboraciones con la vida cultural del país, son también una fuente de intercambio a tener en cuenta, dada la cercana relación del escritor con Lezama. Por último, los concursos literarios en que participaron respectivamente, y las responsabilidades frente a la cultura de sus países, hacen imposible que nuestros autores en cuestión desconocieran sus obras respectivas desde sus meros comienzos. En suma, relación humana aquí se refiere al despliegue epistolar a terceros, al intercambio cultural del hombre escritor versus la relación intertextual o semiótica a nivel de textos o del lenguaje, de la que me ocuparé en su momento.

Es cierto que escasean las alusiones directas en el caso de Borges y Lezama, sobre todo en el caso de Borges. Lezama menciona y cita a Borges en algunas ocasiones, 
como veremos. De todos modos, la obliteración o el silencio es sintomático, sobre todo si se piensa en hombres que compartieron la misma profesión, afanes fundacionales en cuanto a estética e identidad parecidos, gustos afines y una época común de renovación y búsqueda. Es casi un silencio cómplice, basado quizás en el hecho de saberse renovadores y en ese estoicismo que da la sabiduría, de las que tanto Borges como Lezama se sabían poseedores. Estaban suficientemente preocupados en sus propias creaciones y se respetaban a distancia. También pienso que Borges, por ética intelectual, no quiso pasar por encima de una relación, con la intelectualidad cubana, que inició José Rodríguez Feo. Los intercambios culturales entre Borges y Lezama, por llamarlos de alguna manera, fueron siempre propiciados por los admiradores de uno y otro, que acudían a ellos con propuestas y exigencia de textos, pero nunca partió de ellos propiamente. La última e infeliz posibilidad, es que a Borges sencillamente no le interesara la obra del escritor cubano, lo cual no impide que la crítica póstuma los vincule estéticamente.

En uno de los primeros números de la revista Orígenes, ${ }^{11}$ dirigida por José Rodríguez Feo y Lezama, Cintio Vitier publica un prolijo artículo titulado "En torno a la poesía de Jorge Luis Borges.” Este artículo, como nos hace saber el propio Cintio Vitier, lo encomienda Rodríguez Feo:

Recuerdo que mi trabajo sobre la poesía de Borges me lo pidió Rodríguez Feo, así como un comentario sobre Las Ratas, de José Bianco. Rodríguez Feo, aparte de sufragar la impresión, desempeñó un papel importante, por la amplia red de contactos con escritores extranjeros que estableció, y que 
resultó decisiva para el prestigio internacional de la revista. ("La amistad" 70)

Según Cintio Vitier, fue Rodríguez Feo, por su posición económica, quien estableció el lazo entre la revista Orígenes y la literatura universal. En el caso de Argentina también ocurrió así. Una prueba de esa relación lo constituye el hecho de que la revista $\underline{\text { Sur, }}$ dirigida por Victoria Ocampo, fue anunciada en las páginas finales de casi todos los números de Orígenes, hasta que José Rodríguez Feo se retiró de la dirección de esta última. Sur aparece anunciada por primera vez en Orígenes, tan pronto como en 1945, año II. Núm. 6, y aparece por última vez en el número 37 del año 1955. A partir de ese número, Lezama comenzó a fungir como único director de la revista.

Como parte de dicho intercambio facilitado por Rodríguez Feo, Orígenes también se anunciaba en las páginas de $\underline{\text { Sur, }}$ revista en la cual Borges publicó innumerables textos. Virgilio Piñera se refiere a los anuncios de Orígenes en una carta a Lezama del 22 de

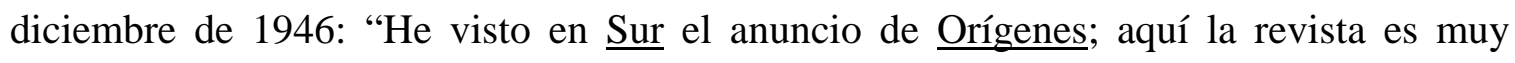
considerada" (Cartas 279). En una carta posterior por el contexto, pero sin fecha, Virgilio Piñera le pide a Lezama números de Orígenes por la acogida que la ésta ha tenido en los círculos intelectuales argentinos: "Te suplico que me envíes mayor cantidad de Orígenes, aquí muchos la quieren leer" (283). Lezama aparecía como una figura de fondo. Se dedicaba rigurosamente al trabajo de la revista y a la elaboración de su obra, pero ciertamente no era de los más populares. Sus artículos hablaban sobre cultura, filosofía y poética o se dedicaban a sus poemas y a capítulos de $\underline{\text { Paradiso, }}$ generalmente.

Otro ejemplo del trabajo de los admiradores en acercar, según nuestro propósito, a Borges y Lezama es precisamente el caso de Virgilio Piñera. El dramaturgo cubano, en 


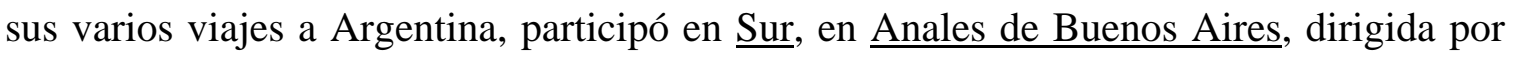
Borges, y en otras revistas literarias de la época como La Nación, tal y como nos da a entender en la citada carta del 22 de diciembre de 1946: "Aquí generalmente se cobra de 10 a 15 dólares por artículo; con excepción de La Nación que paga 80. Pero $\underline{\text { Sur paga } 60}$ y Anales me pagó 40” (279). Virgilio Piñera publicó en la revista dirigida por Borges más de una vez: "Publiqué en Anales de Bs. As., que dirige Borges, un cuento titulado 'En el insomnio'”' (279).

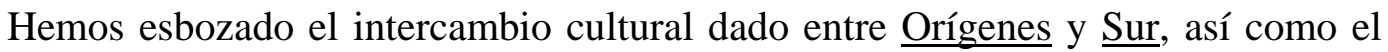

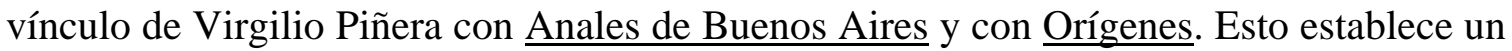
puente importante entre la literatura más fresca e innovadora de la Cuba del momento, y

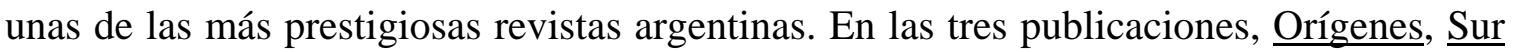
y Anales de Buenos Aires aparecen Lezama y Borges, respectivamente, como figuras conspicuas, de primera calidad; pero, además, con responsabilidades importantes respecto al curso de dichas publicaciones. Conviene ahora una revisión del artículo titulado "Nota sobre literatura Argentina de hoy", por las implicaciones que éste arroja en términos éticos para las revistas Anales de Buenos Aires y Orígenes y, por extensión, para Borges y Lezama.

Dicho artículo aparece simultáneamente en Anales y en Orígenes. En este caso Borges pidió el artículo que hablaba sobre él, por eso, aún consideramos la colaboración mediada por Virgilio Piñera en el caso de la aparición del artículo en Orígenes. Virgilio Piñera explica a Lezama las razones que lo llevaron a entregar a Orígenes y a Anales la misma publicación, debido a que las revistas exigían artículos inéditos. Dice Virgilio Piñera en la citada carta sin fecha: 
En relación con el ensayo mío que te enviara, quiero decirte lo siguiente. Borges escuchó la lectura del mismo por la radio del estado (yo lo leí hace varios meses por dicha radio) y hará cosa de quince días me lo pidió para publicarlo en Anales. Yo le hice saber que lo había dado para Orígenes pero acepté pues como quiera que son dos revistas de distintos países no se interfieren la una y la otra; además, de que esto se estila entre revistas. Quiere decir, que tan inédito será para Orígenes como para Anales. (Cartas 283)

Al parecer, ni Borges ni Lezama tuvieron objeciones al respecto. Los artículos aparecieron en ambas publicaciones y la colaboración continuó posteriormente. Es cierto que el artículo era sobre literatura argentina, lo cual no nos dice mucho de la información que Borges pudiera tener sobre el trabajo de Lezama. Pero de alguna manera sabía que

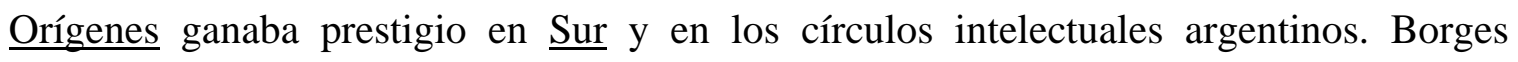
también sabía que un artículo con ásperas frases sobre su propia literatura se publicaba en La Habana. Estas razones conducen obviamente a suponer que Borges conocía la obra de Lezama aparecida en Orígenes, revista de la cual Lezama era director y en la cual Borges aparecía publicado.

El artículo en cuestión, "Nota sobre literatura Argentina de hoy," considera a Borges un tanto enajenado. Virgilio Piñera critica la excesiva adhesión de Borges al tema extranjero y la construcción de sus argumentos más preocupados por la forma que por el contenido en sí. Comenta Virgilio Piñera refiriéndose a la ficción de Borges:

Tomemos cualquiera de sus relatos -éste que se llama "Tertius Orbis" [sic] o aquél que se titula "Pierre Menard, autor del Quijote." Son 
tantálicos en cuanto que la construcción que los ha precedido está hecha por la construcción misma, pero el obligado resorte vital que la justificaría no aparece en la misma [. . .] se ve muy bien que Borges está más preocupado (o que sólo puede preocuparse), por la experiencia libresca, por la altura, por la entelequia del tema que por la necesidad real de manifestar sus propias contradicciones. ("Notas" 44)

Según Virgilio Piñera, Borges solicitó el artículo al escucharlo en la radio y luego lo publicó en Anales. De esta manera Borges comparte la publicación de su artículo con la revista Orígenes, y da a conocer la opinión sobre su obra que circuló en Cuba. Por un lado, esto es un elemento a favor del vínculo que venimos esbozando como he mencionado; por otro, nos indica el interés de Borges por la opinión sobre su obra y de alguna manera nos habla, más que de su humildad, de su convencimiento en que la obra, una vez escrita, "pertenece a la tradición."

En opinión de Mark Richard Couture, "Piñera's critique is not only directed at Borges, the director of Anales de Buenos Aires, but directed at Lezama as well, the director of Orígenes" (Secret 253). En esta misma línea de razonamientos, Cintio Vitier nos hace saber que Virgilio Piñera funda la revista Poeta "de agresiva orientación antilezamiana" ("La amistad" 51), después de desaparecer Espuela de Plata. Esto convalida la opinión de Mark Richard Couture. Virgilio Piñera une a Borges y Lezama en su embestida al tratamiento barroco y esotérico de la literatura. Según el criterio estético con que Virgilio Piñera estaba juzgando a Borges, es entendible que Lezama cayera bajo el mismo calificativo de "tantálico". 
La convergencia entre Borges y Lezama tiene lugar en los substratos de la concepción filosófica, en la poética y en la teleología, como ya mostraba Lezama desde "Muerte de Narciso" y Borges desde Fervor de Buenos Aires. Borges y Lezama se ven en el "otro" de alguna manera. Regresemos, por un instante, al artículo sobre Borges que Cintio Vitier publica en la revista Orígenes en el año 1945. En esta ocasión nos centramos en la temática y no en probar la fuente de los vínculos como vimos anteriormente. En "En torno a la poesía de Jorge Luis Borges," Cintio Vitier detecta varios temas de la escritura de éste. Los temas específicos son: la angustiosa presencia por la vida, la aplicación del "principio leibniziano de los indiscernibles a los problemas de la individualidad y del tiempo"; las hipótesis de Schopenhauer y Berkeley; el eterno retorno y variaciones sobre la noción del infierno. Cintio Vitier concluye que "la lectura de las Anotaciones al cuaderno titulado Muerte de Buenos Aires, y las Notas finales del libro, nos ilustran suficientemente sobre tales inquietudes" (36).

Los elementos sobre el tiempo, el existencialismo y el corsi et recorsi viquiano de la historia, en la poesía de Borges, son detectados por Cintio Vitier y expuestos en la revista Orígenes desde 1945. Ya desde entonces se respetaba la obra del argentino, y se detectaba cierta afinidad por los de Orígenes. En la búsqueda de renovación formal que implicaba la revista, declarado incluso en su título "orígenes," se establecía una resonancia con valores estéticos universales, que la separaba de las vanguardias de la isla. Respecto a esto dice Cintio Vitier:

Si algo caracterizó a los poetas que podemos llamar conductores del mensaje central de Orígenes (1944-1956), fue su distanciamiento, no sólo de las superficiales cabriolas del efímero y desvaído vanguardismo 
cubano, cuyo órgano, predominantemente ensayístico, fue la $\underline{\text { Revista de }}$ Avance (1927-1930), sino incluso de las mejores consecuencias que se derivaron de su impulso: las llamadas poesía "pura" y "social". Ese distanciamiento no fue ni siquiera polémico, lo que de algún modo establecería alguna relación. Se sustanció, en principio, con más lejanía que desdén, y sin ninguna acrimonia [. . .]. ("La aventura" 309)

La cita está en el centro de preocupaciones de esta tesis. Es precisamente en ese "distanciamiento" de la poesía pura y social, "con más lejanía que desdén," donde reside la afinidad poética entre Borges y Lezama. El estudio sobre Borges es amplio y específico en cuanto a sus lineamientos estéticos. Es cierto que Orígenes, en general, se preocupó por la actualización en muchas de las tendencias en boga y fue inclusivo; pero el caso de Borges no fue una coincidencia más.

Diez años después, en 1955, Roberto Fernández Retamar publicaba un artículo sobre Borges titulado "América, Murena, Borges," en Orígenes. Es decir, la obra de Borges siempre se siguió desde la Habana y fue en las publicaciones que dirigió Lezama donde más se popularizaron sus textos. Es obvio que Lezama estaba al tanto de la obra de Borges, de sus principales tendencias o preocupaciones, y que su celo profesional, puesto en la labor de Orígenes, que junto con José Rodríguez Feo Dirigía, hablaba por sí sólo de la alta estima en que tenían al escritor argentino. La estética de Borges resultaba afín a Orígenes. Cintio Vitier y Lezama juzgaban la escritura de Borges de gran calidad. Por otro lado, la revista se alejaba de las "cabriolas" y el utilitarismo derivado de las vanguardias, al decir de Cintio Vitier. 
Enfocando ahora al lado opuesto, tenemos a Virgilio Piñera considerando a Borges como un "tantálico". La suma de todas estas ideas, nos hace converger en una estética muy cercana, en valores artísticos afines entre Borges y Lezama; algo de lo que, en mi opinión, ambos estaban enterados, aunque no compartieran la forma de expresar estos valores. Virgilio Piñera consideraba escapista, la posición de Borges y Lezama, mientras Cintio Vitier, tildaba de "cabriolas vanguardistas" la tendencia opuesta, y su evolución posterior.

En otras ocasiones, Virgilio Piñera emitió comentarios semejantes sobre la expresión barroca de Lezama, aunque ello no rebajó la profunda admiración que el dramaturgo sentía por éste. Lo importante aquí es observar un elemento. Borges y Lezama están unidos bajo una misma perspectiva, que no es más que la irrupción de una nueva (o sempiterna) estética, ya sea neobarroca, ya sea profundamente renovadora, pero no bien definida positivamente. En ocasiones Virgilio Piñera los consideraba barrocos, en otras Cintio Vitier, yendo en sentido opuesto, los consideraba esencialmente criollistas, Roberto Fernández Retamar los valora profundamente americanos y Julio Ortega en una aproximación más delimitada nos dice:

Borges es más sarcástico, con desapegos criollos; Lezama más sensorial, con apegos no menos criollos. Son polares pero complementarios: en el comienzo de la poesía argentina, Borges comprueba que no se menciona el color local, en cambio Lezama comprueba que el primer poema cubano es una receta de cocina. La risa de ambos subraya la Babel urbanizada de las enciclopedias y los diccionarios. Pero si Borges fue cautivado por el espacio vacío de los viajes, para él, en verdad, una permanente 
conversación literaria; Lezama no salió casi de su isla imaginando una "teleología insular" como el espacio pleno de su caminata idéntica. (Lezama 248)

En una valoración posterior, Julio Ortega se refiere a Lezama: "como un artesano del sentido: como Borges, pero más allá de Borges" ( $\underline{\text { Screen } 1) .}$

De alguna manera, Lezama sentía esta empatía y se colocó del lado de la admiración y la meditación cadenciosa respecto a Borges. En más de una ocasión, José Rodríguez Feo hizo comentarios desfavorables sobre la obra de Borges, a los cuales Lezama nunca respondió en el mismo tono. En una carta de abril 1946, Rodríguez Feo

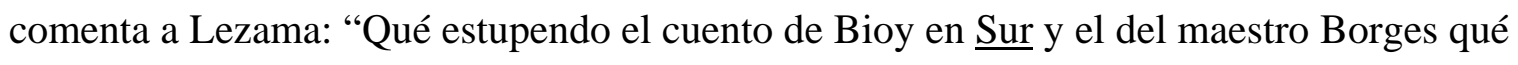
desteñido monótono" (36). Lezama no cayó en la tentación de la crítica, por el contrario, todas las opiniones y comentarios que se recogen en Lezama sobre Borges son apologéticos. Ya en el año 1943 habían aparecido versos de Borges citados por el propio Lezama en el número 5, de junio de la revista Nadie Parecía. En 1949 Lezama se dirige a Jorge Mañach con el siguiente comentario:

No podemos mostrar afiliación, mi querido Mañach, con hombres y paisajes que ya no tenían para las siguientes generaciones la fascinación de la entrega decisiva a una obra [. . .] no era, como en México, con el caso ejemplar de Alfonso Reyes, o en la Argentina, con Martínez Estrada o Borges, donde la gente más bisoña se encontraba. ([Bohemia 40 [1949]: 77] tomado de Couture, $\underline{\text { Secret } 236)^{12}}$

Lezama da muestras de admiración y respeto en actos de modestia, pero también de afinidad al contenido de la obra de Borges y lo que es más importante, a su ideario. 
Reynaldo González refiere una conversación con Lezama, en la cual el primero hacía comentarios peyorativos sobre un poeta amigo del segundo. Lezama apoya a su amigo poeta usando una frase de Borges: “Está hecha de sutilezas, tiene la eficacia de los adjetivos insustituibles', dijo. 'Aprendida en Borges', respondí. 'Pero no es copia, es hallazgo', insistió" (218). Lezama reafirma que la expresión de Borges usada, implica un hallazgo y no una copia. Lezama ha descubierto la frase y la ha incorporado a su archivo de frases y obras. Quien esté familiarizado con los cursos délficos lezamianos entiende la importancia de que Lezama considere la frase de Borges un hallazgo y no mera repetición literaria. Nos hace saber el narrador de Opiano Licario: "Licario tenía el convencimiento de un conocimiento oracular en el que cada libro fuera una revelación, con eso se evita el fárrago de lecturas innecesarias en que caen los adolescentes" (Oppiano 426). Luego, la frase de Borges merece otra calificación que la de fárrago innecesario. Pudiera aventurar, así mismo, cierta asociación entre la idea que yace en "Pierre Menard autor del Quijote" y este deslinde entre copia y hallazgo.

En la propia conversación con el crítico, Lezama llega a una afinidad aún mayor con el arte y el pensamiento de Borges cuando asevera:

Es cuestión de antípodas equilibrantes. Eso que ustedes llaman unidad y lucha de contrarios. Todo haya en su opuesto su caja de resonancia. A veces el eco se cansa de repetir y contradecir. Entonces comienzan los caminos nuevos, ese "jardín de senderos que se bifurcan" borgiano, y que es bueno si el hombre va a transitarlos para hallarse a sí mismo. (González, "Lezama a la altura de los ojos" 219) 
Esta cita debe entenderse en el contexto de la ideología fundacional de la revolución cubana. Cuando Lezama dice "eso que ustedes llaman unidad y lucha de contrarios" se está refiriendo a las socorridas categorías marxistas tan sabidas y repetidas por entonces. La cita muestra cuán lejos va Lezama en su vocación borgeana, al asociar uno de los lemas de la revolución cubana a un texto de Borges ${ }^{13}$. Lezama primero se distancia de la opinión del entrevistador al decir "eso que ustedes llaman" y luego se afilia a la opinión del escritor argentino, al afirmar que la categoría dialéctica marxista, "unidad y lucha de contrarios" está recreada en la obra de éste, a través de la plenitud de la imagen.

Para Lezama la imagen contiene al potens que no es más que la posibilidad infinita de la imagen misma, ${ }^{14}$ pero que a su vez aporta esta característica generatriz del par dialéctico mencionado. Según Lezama, en el "jardín de senderos que se bifurcan" borgeano está la dialéctica marxista contenida por exceso. Pues ésta se expresa artísticamente con toda la dimensión humana que presupone el arte; y está alimentada por la carga existencial del cuento. Lezama va incluso más lejos en su afinidad, al otorgarle un rasgo individuo-existencial al concepto, a contrapelo de la vocación colectiva implícita en la idea original expresada en la teoría marxista, cuando dice: "Y que es bueno si el hombre va a transitarlos para hallarse a sí mismo" (219). Esta aseveración existencial muestra una afinidad con la visión de Borges sobre el individuo y la historia.

Lezama responde al hombre social, al hombre nuevo (que en su opinión había existido siempre) con el escepticismo epistemológico borgeano y prueba su efectividad al lanzarlo contra el progresivismo que implica el par dialéctico unidad y lucha de contrarios, según los ejemplos con los que se apertrechaba la teoría. Recordemos que ese jardín de senderos que se bifurcan "es una imagen incompleta, pero no falsa, del 
universo" (Obras completas 1:479). Aquí se solapan las poéticas otorgando a la imagen esa posibilidad de ser cápsula del conocimiento. Estamos frente al pensamiento por imágenes de Vico donde el arte se presenta como productor de sentido, a través de la síntesis metafórica. Según Bejel: "Lezama desarrolla el concepto de 'eras imaginarias', enraizado en una concepción trascendental del sujeto, y de una historia que es la imagen de Dios encarnado en el tiempo. Tal concepto se asemeja mucho al de Giambattista Vico, que veía la historia como el devenir de la Providencia manifestándose en ciclos que afirmaban el proceso histórico" ("Cultura e historia” 245).

Lezama, por otra parte, responde en entrevista con Armando Álvarez Bravo: Mi sistema poético se desenvuelve, como es lógico pensar, dentro de la historia de la cultura y de la imagen [. . .] así inscribo en su umbral una serie de sentencias de muy profunda resonancia. La primera es de San Pablo, y dice: Charitas omnia credit [. . .] A su lado coloco una de Juan Bautista Vico: Lo imposible creíble. Es decir, el hombre por el hecho de ser creyente, de habitar el mundo de la caridad, de creerlo todo, llega a habitar un mundo sobrenatural pleno de gravitaciones (Álvarez 23)

Lezama jerarquiza los procesos de la "historia de la cultura y de la imagen" que contienen esa imposibilidad creíble que sólo logra la imaginación. Esta imposibilidad creíble está vehementemente plasmada en el cuento de Borges. Lezama y Borges llevan el concepto de la imagen más allá, con el beneficio de las ciencias actuales. La imagen infinita y resumidora contiene nuestras presunciones teóricas y las inimaginables. 
Digo esto porque pienso que respecto a "El camino de senderos que se bifurcan" Lezama no sólo mencionara la frase, sino que hubiera tenido en mente la intensa imagen que implica el cuento. Según el cuento de Borges, Ts'ui Pên:

Creía en infinitas series de tiempos, en una red creciente y vertiginosa de tiempos divergentes, convergentes y paralelos. Esa trama de tiempos que se aproximan, se bifurcan, se cortan o que secularmente se ignoran, abarca todas las posibilidades. No existimos en la mayoría de esos tiempos; en algunos existe usted y no yo; en otros, yo, no usted; en otros, los dos. (Obras completas 1:479)

Lezama, en su comentario sobre Borges a Reynaldo González, se identifica plenamente con la idea de los múltiples tiempos del argentino, donde todos coexisten. Modelo físico que además tiene infinitas posibilidades de destinos imprevistos. La ironía, otro punto en común de nuestros polos, consiste en que para Lezama la utilidad radica en que el individuo se encuentre a sí mismo, expresado en la frase citada. Pero según el postulado del cuento, existen infinitas posibilidades de no encontrarse. La declaración de Lezama, en consonancia con la idea de Borges, es profundamente existencial, a la vez que implícitamente escéptica.

Estas repetidas alusiones a Borges (o a sus textos) en la creación, comentarios y cartas de Lezama; ${ }^{15}$ la incursión de Orígenes en Argentina; la visita de Victoria Ocampo

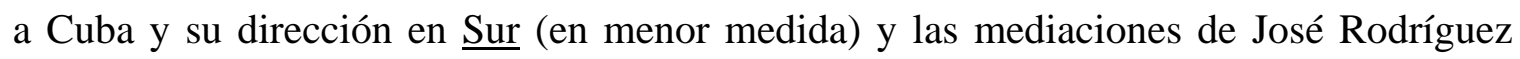
Feo y Virgilio Piñera muestran que, a pesar de no haber existido una relación directa entre Borges y Lezama, hubo una fuerte empatía. Dicha empatía es expresa en Lezama; subyacente en Borges, pero vigente de igual manera. No debemos pensar que el 
distanciamiento de Borges equivale a una idea original en éste que dejó su impronta en Lezama y ver la empatía en un sólo sentido.

Varios elementos nos ayudan a demostrar que Lezama desde un inicio sostuvo una firme convicción de sus posteriores fundamentos: sus opiniones sobre el surrealismo desde un origen sufrieron mucha menos corrección que las opiniones de Borges; la estructura especular que señala Paul DeMan en los cuentos de Borges, desarrollada posteriormente con amplitud por Jaime Alazaki en Versiones. Inversiones. Reversiones, es eje central en "Muerte de Narciso," que se publica en 1937, y nutre el eros cognoscente del que nos habla Emilio de Armas en su introducción a Poesía (57). Como nos hace saber Alina Camacho-Gingerich: "El espejo desempeña una función importante en el concepto lezamesco del Eros y la imagen, [. . .]. El espejo no sólo reproduce sino que desdobla, multiplica" (110). En Lezama, el espejo es siempre figura central como imagen, mientras que en Borges los es como estructura.

El panteísmo religioso (de religare) que nutre y conforma la cosmovisión lezamiana está expresado desde el inicio en el grupo Orígenes, y en la revista del mismo nombre. Este afán sistémico y ecuménico se hace patente desde sus revistas anteriores. Los elementos de paganismo que refuerzan lo mítico arquetípico en los textos de Lezama también están expresados desde sus primeros poemas, a través del gusto por lo helenístico y el orientalismo, entre otros. De manera que, entre estos y muchos otros elementos semióticos que nutren la empatía de los dos autores, se debe ver una evolución genuina y propia en cada uno de ellos y de ninguna manera una influencia unidireccional.

Se puede pensar en varias causas de este silencio por parte de Borges. Si recordamos que la relación con Argentina la inició Rodríguez Feo, pudiéramos pensar 
que Borges no quiso ir por encima de esa relación, una vez que Rodríguez Feo abandonó la revista Orígenes. ${ }^{16}$ Por otro lado, quizás ambos vieron con agrado ese reflejo de su ideario en la obra del otro, pero no quisieron dejar falsas pistas que se pudieran interpretar como simples imitaciones. Borges se defiende de esa acusación implícita innumerables veces convenciendo al lector de que no hay obra genuinamente original o prístina (o afirmando que no leía a sus contemporáneos)(Alazraki, Critical 7). Después de Homero, de los hombres para los que hablar en metáforas era una ciencia o una verdad, la poesía es un juego y a él se entrega el "reescritor" de "Pierre Menard: autor del Quijote." La idea de que existe un sólo libro o de que los arquetipos nos obligan a escribir siguiendo el algoritmo de un orden universal inexorable, está levitando en cada creación fictiva de Borges. Esta idea opera como motor fictivo, a la vez que como justificación contra el plagio o la intertextualidad literaria.

Estos elementos conforman en Borges su ficción de racionalidad, y justifican su plena conciencia, de que somos sujetos de corrientes de pensamiento en una época determinada. La aporía de la originalidad total de la obra, parece decirnos Borges, está basada en que nos es imposible conocer esos arquetipos o descifrar ese orden del universo al que nos hemos referido. Nuestra mente percibe estas creaciones como originales al carecer de capacidad de juicio para la comparación ${ }^{17}$. Estos razonamientos enlazan a Borges con la idea posmodernista de la fenomenología y nos muestran que Borges supo entender esas corrientes de pensamiento y usarlas creativamente.

Tal como indica el título de esta sección las relaciones de los dos escritores fue sui generis en toda la dimensión de la palabra. De todos modos, respecto al tema que me ocupa, es importante definir las cosmovisiones de Borges y Lezama y denotar cómo 
operan esos componentes en ambos escritores; más que colegir las causas de un silencio que en definitiva no es relevante ante la calidad de las obras. Borges y Lezama comparten visiones, fundamentos filosóficos, estrategias de creación y hay evidencias de que ambos estuvieron enterados de sus pautas respectivas. El hecho de que Lezama es explícito en reconocer la maestría de Borges y el segundo prefirió ser discreto en ese respecto (cualquiera que sean las causas de ese silencio), no debe impedirnos establecer válidas comparaciones sobre poética. Por eso, en la siguiente sección, en lugar de dedicarme a las conexiones directas entre los polos de la comparación, me centraré en exponer esos lazos semióticos que se establecen a un nivel más amplio.

\section{b. - Los raros}

El vocablo "raro" posee aquí un doble significado. Por una parte significa eso que no se encuentra, que es de naturaleza escasa; por otra; significa un comportamiento conspicuo o extraordinario. Aunque ambos conceptos están relacionados, aquí propongo diferenciar a Borges y Lezama de la corriente dominante en la época desde el punto de vista de la filosofía y de la praxis literaria. Me ocuparé en demostrar esos elementos que he mencionado al inicio de mi estudio y que reúnen a nuestros autores bajo ciertas características peculiares. Los elementos en cuestión son: antimaterialismo; alejamiento de la inmediatez; fuentes literarias que influyeron en sus cosmovisiones; tratamientos de los géneros literarios; acercamiento a la poetología y por último la épica a través del ancestro militar. Primero, intentaremos entender las premisas en que se basan las cosmovisiones de ambos autores, teniendo en mente que esta sección realiza una comparación con la literatura regional del periodo. Más adelante, en la discusión sobre poética, abordaré la visión filosófica como forma de asentar una expresión literaria y de 
explicar el mundo a través de la escritura, análisis que sustentaremos con un estudio textual.

Los elementos visibles que distancian a Borges y Lezama de la corriente de pensamiento que sustentaban los escritores del boom latinoamericano son el antimaterialismo, el tratamiento de la inmediatez, y la ficción de racionalidad. En ambos autores se detecta una forma de idealismo perceptual, que sin discutir ahora si es una convicción filosófica o un recurso fictivo, alimenta sus poéticas y los lleva a reflejar preocupaciones de índole estéticas y metaliterarias. Ambos están en el centro de la socorrida discusión sobre el rumbo de la literatura, pero se contraponen explícita o implícitamente al uso utilitario de la literatura fuera de un ideal hedónico.

Se han definido dos tendencias básicas como substrato de las poéticas de Borges y Lezama. Se dice que Borges parte del surrealismo, su tendencia ultraísta (Borges el

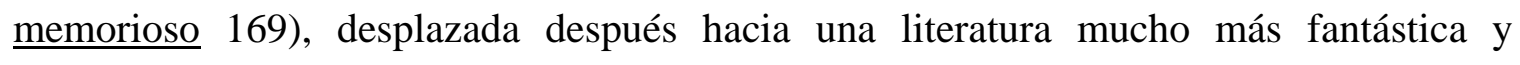
metafictiva, es aceptada en su mayoría por la crítica. A Lezama se le atribuye la redefinición del barroco en un neobarroco que ha tenido su teoría en Severo Sarduy. Esta última teoría había encontrado su fundamento telúrico en los ensayos de Carpentier sobre lo real maravilloso, consignando que el continente latinoamericano es la tierra de lo verdaderamente real maravilloso por excelencia y por extensión del barroco. ${ }^{18}$

Sucede que las humanidades no son ciencias exactas y cualquier aseveración puede ser casi verdad si se busca el contexto adecuado. Borges nos ha dado suficientes ejemplos de esto. No hay dudas de que el surrealismo fue una forma de ver el mundo estéticamente y que tuvo indiscutible influencia en todos los escritores de principio y mediados de siglo; como tampoco las hay de que el barroco es un estilo universal que 
encuentra expresiones en los rincones más alejados del planeta, sin influencia de escuelas barrocas propiamente dichas. Sobre esto se pronunció Lezama en la "Conferencia sobre Manuel de Zequeira y Manuel Justo de Rubalcaba” en 1966:

Yo recuerdo, por ejemplo, que un cuadro clásico de la pintura china se llama Lavado del rostro de la luna por un hada gentil asistida por un dragón complaciente y, desde luego, esto no tiene que ver nada con el barroquismo. Y otro, por ejemplo: Tin Sang Fo robando los melocotones de la longevidad, que tampoco forma parte de ninguna escuela barroca. (Lezama, "Conferencia..." 69; la bastardilla es de Lezama.)

Para Lezama, el barroco es una forma de retórica, de expresión, de ver y de hacer ver; al igual que para Borges el surrealismo, la metafísica o el propio barroco se convierten en una manera efectiva de armar la ficción. ${ }^{19}$ Borges también acepta su inicial pasión barroca. Refiriéndose a Bioy Casares en una entrevista con Antonio Carrizo nos confiesa: "El fue curándome, poco a poco, de mi amor por lo barroco" (Borges el memorioso 79). Tanto el estilo barroco como el uso de perspectivas no realistas formaban parte de los nuevos derroteros.

Sin embargo, los autores que nos ocupan no se quedaron ahí, en el uso de ese substrato estético de época. Ellos evolucionaron a formas más individuales y universales a la vez. Al respecto, el crítico Santiago Juan-Navarro comenta, refiriéndose a Borges, al discutir un estudio sobre postmodernidad en América Latina de Julio Ortega: “Although his literary beginnings were closely linked to the avant-garde and, especially, to 'ultraísmo,' Borges moved progressively away from these positions to eventually become the main transgressor of 'institutional modernism' 1988:195 (30). 
¿Qué forma de ver, qué perspectiva nutre en su substrato primario esa escritura barroca, panteísta, surrealista o fantástica de estos escritores y que en definitiva deriva en una escritura original imposible de clasificar con las tipificaciones creadas para otros escritores de la época? Si Borges se concentra en una instancia posterior a la sensación, en esa instancia perceptiva donde se desconfía de estas sensaciones, derivando de ahí su "ilusión" cíclica de la realidad y la literatura, Lezama se mantiene en el plano de la sensación. Su experiencia sensorial es sumamente rica y llega a conceptualizar estados sensoriales no conocidos por la literatura hasta ese momento. Su "vivencia oblicua" o lo transtelial son compensaciones verbales a esa aguda observación, que le permiten conceptualizar lo no entregado por los sentidos.

Lezama crea la realidad mediante la poesía y a ésta podemos llegar sólo por medio de la imago. La imago lezamiana es también un proceso de conceptualización de las sensaciones. Tal es el caso del poema "Himno para la luz nuestra" del cual cito a continuación: "Aunque el oído me da la fe/ la visión como un mastín rastrea/ lo que el arcángel flamea/ en el punto donde no se ve" (Lezama, Poesía 215). El debate sensorial entre lo escuchado y lo observado establece una dicotomía del mundo que percibimos. El juego sinestésico llega al oximoron al decir "la visión como un mastín rastrea". Tenemos una información entregada por la audición, pero la visión no confía de ese registro y se comporta como el olfato de un mastín, indagando nuevas perspectivas de una flama existente en un punto invisible. La metáfora sirve de apoyatura para construir una realidad que no existía, sólo yacía intuida por un conjunto de sensaciones confusas. La metáfora descubre lo encubierto, parece decirnos Lezama. 
Cuando Borges nos dice en "Los espejos velados": "Es común referirse a las mujeres, para intimar con ellas, rasgos verdaderos o apócrifos del pasado pueril; yo debí contarle una vez el de los espejos [. . .].” (Obras completas 2:164), nos está narrando desde la memoria. Borges no verbaliza sensaciones al estilo lezamiano. Su narración viene de lo profundo de su mente y es una introspección en la que se verbaliza la memoria. Líneas adelante en el mismo relato Borges nos dice: "Ese odioso destino de mis facciones tiene que hacerme odioso también, pero ya no me importa" (164). Al inferir el efecto de "mis facciones" Borges suplanta la sensación por la suposición. Su mecanismo discursivo jerarquiza el razonamiento.

Otros ejemplos de este mecanismo, donde el narrador llega más lejos intelectivamente en su propuesta, los encontramos en "El cautivo" y en "Delia Elena San Marco". En el primero, la sorpresa del cuento radica en la imposibilidad del autor/lector de sentir por el indio: "Yo querría saber que sintió en aquel instante de vértigo en que el pasado y el presente se confundieron" (166). En el segundo ejemplo el narrador contrapone la importancia de la memoria y los sentidos cuando comenta su asombro: "Y ahora yo busco esa memoria y la miro y pienso que era falsa y que detrás de la despedida trivial estaba la infinita separación" (168) y concluye con la obliteración total de los sentidos: "Delia: alguna vez anudaremos ijunto a qué río? Este diálogo incierto y nos preguntaremos si alguna vez, en una ciudad que se perdía en una llanura, fuimos Borges y Delia" (168). Aludiendo al río de Heráclito, el narrador ha impuesto la perspectiva racional versus la sensorial. Borges destruye, invalida lo entregado por los sentidos; Lezama pretende construir la realidad, a partir de integraciones sensoriales que se metaforizan. 
De esta manera ambos escritores coinciden en que la cultura debe ser rescrita, en que nuestra concepción del mundo no es "real". Pero sobre todo, en que la única verdad que nos queda es la literatura, la belleza del lenguaje. Borges se dedica a demostrarlo, construye, como en "Las ruinas circulares," un complejo andamio para su proposición y en su verosimilitud logra los más finos matices. Pero su especialización en esa forma de ver lo mantuvo en el escepticismo. Lezama intenta crear un sistema que explique el universo en conexión con Dios (religare) y en su complejidad al acercarse al objeto, creó un lenguaje críptico. Pasó a un barroco a veces incomprensible.

La conexión entre el escepticismo epistemológico y la duda en el registro de las percepciones en Borges, ha sido expuesta por el crítico Donald Shaw, quien asevera que Borges es un agnóstico, pero también "rechaza con suave ironía el concepto convencional de Dios" (33). De este agnosticismo se deriva el escepticismo en opinión del crítico, quien llega, por una regla de tres, a la siguiente conclusión:

Si no existe un Dios que garantice la veracidad de las impresiones que recibimos a través de los sentidos, y si la razón se confiesa incapaz de explicar tanto el mecanismo del universo, como el de nuestra mente, se sigue que está desprovista de todo fundamento cualquier confianza en nuestro poder de reconocer y de explicarnos lo verdaderamente real. (Shaw 34)

Esta cuestión ontológica es esencial a la poética de Borges. Los relatos "La biblioteca de Babel", "El Aleph," "Las ruinas circulares" y los poemas "Casi juicio final”, "El sueño", "Cristo en la cruz", "Los justos", entre otros, son variaciones del tema de la relación del hombre con Dios y la imposibilidad de conocer el universo. 
De cualquier modo Borges no concibe al universo desde una dialéctica hegeliana, ni apoya en sus textos el evolucionismo darvinista, en el que cada fenómeno posterior en el tiempo debe ser superior en calidad. Estas últimas serían ideas muy a la superficie en la época para el gusto de Borges y no tendrían la sofisticación requerida por su propuesta ideo-estética. Lezama, por su lado, asume un sentido panteísta del mundo, su Dios está en todas partes, pero no se revela sino con un proceso de abstracción poética. El autor alude así a conceptos como lo intangible, lo inaudible, la experiencia oblicua para denotar la naturaleza imperceptible del universo e instituir la imagen como única fuerza creadora. Donald Shaw ofrece un contraste entre ambos escritores y sus respectivas ideas sobre la cognoscibilidad del mundo:

La duda de Borges de si el mundo es un caos total, o bien un orden secreto que no sabemos descifrar, está resuelto positivamente por Lezama Lima... al afirmar la posibilidad de 'volver a definir a Dios partiendo de la poesía'. El ‘yonder' de Cortázar es un aquí y ahora para Lezama Lima: la imagen, la resurrección del hombre mediante la palabra poética. (156)

Si bien Lezama intenta crear una "cosmogonía donde la poesía pueda sustituir a la religión" (Introducción 31), como nos hace saber Eloísa Lezama Lima; el definir a Dios desde la poesía resuelve sólo parcialmente el dilema sobre el caos o el conocimiento del orden del universo, puesto que las imágenes portan su consustancial inefabilidad. La irradiación de la imagen nos deja en una prelógica de difícil intelección.

En concordancia con esta visión cíclica o sempiterna del orden universal, que pudiera verse comprobada estéticamente en la existencia de arquetipos eternos o de imágenes preexistentes a la humanidad, que debemos constatar, la poética de los 
escritores en cuestión rechaza las relaciones causales directas. A ambos se les ha adjudicado el usar una lógica anti-aristotélica o una prelógica, como indica el propio Lezama en su afán de decantar lo poético: "Es para mí el primer asombro de la poesía que sumergida en el mundo prelógico, no sea nunca ilógica" (Eras imaginarias 33). Jaime Alazraki en su ensayo "Oxymoronic Structure in Borges' Essays" delimita esta estructura de pensamiento en el ensayo borgeano. Comenta el crítico comparando a Borges con Martínez Estrada:

Reading the essays of Martínez Estrada and those of Borges, the reader immediately perceives a similar intention; both deny the efficacy of photographic realism and both mistrust Aristotelian logic...In opposition to Martínez Estrada's enthusiasm -an enthusiasm for a true order- Borges expresses a flat skepticism: if there is an order in the world, that order is not accessible to man. In both writers we find rejection of philosophical idealism, but in Borges this rejection is also a form of acceptance. (48)

Jaime Alazraki, en su estudio, muestra cómo el idealismo filosófico de Borges es también un recurso fictivo que vincula, como nunca antes, el pensamiento crítico y artístico. La alusión a temas teológicos y metafísicos forma parte, igualmente, de estos recursos, como veremos más en detalle posteriormente.

El pensamiento filosofico-religioso es un recurso que tanto Borges como Lezama usan en sus textos. Lezama utiliza más la alegoría del sufrimiento de Cristo implícitamente, a través de presentarse él mismo como un mártir en el yo poético ("Muerte de Narciso", "Rapsodia para el mulo"); en cambio, Borges, aunque también denota esa imagen de intelectual "recogido" y monjil, se refiere a Cristo explícitamente y 
se cuestiona su importancia: “¿De qué puede servirme que aquel hombre/ haya sufrido, si yo sufro ahora" (Páginas 95). Es decir, ambos usan de la religión como un recurso fictivo y ambos nutren así mismo el paganismo como elemento de intriga a las propias ideas religiosas. Aprovechan la imagen religiosa para garantizar efectividad en la expresión. Borges tiene un estilo parabólico que parodia la Biblia; Lezama una imagen que basa su antigüedad en la sabiduría colectiva de la religión. No debe verse a Borges como totalmente escéptico y a Lezama como ortodoxamente religioso.

En las ficciones de Lezama se incluyen una serie de conceptos paganos y del esoterismo clásico que suman a la concepción cristiana una especie de amplitud y enigma. Un ejemplo de lo que vengo diciendo es el poema "Muerte de Narciso" (Poesía 75). ${ }^{20}$ En opinión de Emilio Bejel: "Se debe observar, no obstante, que la religiosidad lezamiana se basa con frecuencia en estructuras conceptuales paganas: el ser, el ente, el sujeto, etc." (“Cultura e historia” 243). Creo que en cierta medida, el haber abandonado el cristianismo ortodoxo le insufla a la obra de estos autores una carga mitológica efectiva.

El Dios del autor de Paradiso es originario al estilo de Cronos o al estilo de una conciencia universal que ordena el universo. Muy parecido al idealismo borgeano alimentado de la concepción de Berkeley, en la que el mundo material y el análisis científico no entran en contradicción con las creencias religiosas. Lezama intenta entonces armar el universo desde la poesía. La palabra es la conformadora de ese mundo cuyas sensaciones almacenamos y verbalizamos. Al respecto, dice Eloisa Lezama Lima: "El desmesurado intento de fundamentar un sistema poético del universo -el más caro 
afán de Lezama Lima- implica un anhelo de mostrar y obsequiar generosamente una cosmogonía donde la poesía pueda sustituir a la religión" (Introducción 31).

En mi opinión, el surrealismo fue una de las corrientes estéticas de más influencia en el siglo XX y sin duda su fragmentación de la realidad se nutrió de los estudios de Sigmund Freud sobre el sicoanálisis. La mayoría de los escritores del boom latinoamericano y su periferia expresaron estas influencias a través del onirismo, como lo hace Cortázar u Onetti. En el caso de Borges y Lezama, la ruptura de la relación causa y efecto y su consecuente cuestionamiento del tiempo histórico tiene raíces filosóficoreligiosas profundas, como también las tiene el antimaterialismo presente en ambos.

La relación entre el materialismo literario y el idealismo se encuentra esbozada por Claudio Guillén de manera convincente: "Cuando el materialismo llega hasta acentuadísimos extremos a priorísticos y monistas, es evidente que aparece una forma oculta de idealismo y hasta de racionalismo" (129). El idealismo de Borges y Lezama tiene intención renovadora. En estos escritores existe una intención de ruptura que apunta a la deconstrucción. Apunta, en definitiva, a desarticular un discurso ortodoxo y centrado en la modernidad, donde la historia era devenir incuestionable y la religión una institución humana tangible. La estética de Borges y Lezama también se enfila contra el desarrollo de las ciencias y la tecnología, que amenazan al arte como consumo y como practica.

Todo el reciclaje cultural de estos escritores jerarquiza la literatura y sus medios. La religión, por ejemplo, es dependiente de la imagen y funge como recurso fictivo, según he señalado. Donald Shaw se ha dedicado al estudio de la relación literatura/religión en estos autores: "Borges ha declarado categóricamente que toda 
referencia a Dios o a lo divino en sus obras ha de interpretarse como un puro recurso formal" (33). Es claro que Borges saca provecho del tema en sus cavilaciones epistemológicas; pero de alguna manera su aseveración sobre los arquetipos que rigen un secreto orden universal goza de tal armonía en su pensamiento que cabe preguntarse si Borges no piensa en una especie de panteísmo de esencia verbal, un Dios de la imagen al estilo de Lezama. En definitiva, la idea de Dios como verbo nos transportaría a la idea original de la Biblia: orígenes y esencias que tratan de conectar la conciencia social del lector a través de un texto universalmente establecido. Borges repite el conocido recurso cervantino, a fuer de ser Pierre Menard, de garantizar la lectura de su obra con un tema introducido de antemano, para desconstruir desde adentro el propio resultado. Cervantes escribe una novela de caballerías que garantiza su recepción y afincado en ese éxito desmorona el sustento ideológico que las soporta. Borges utiliza las metáforas Dios, Universo, Historia para demostrar que dependen de configuraciones mentales y por tanto de la evolución y/o el antojo humanos.

Tanto para uno como para el otro la literatura preserva la memoria. Para Borges todo es literatura y todo es literaturizable. La memoria social y la cohesión de la comunidad humana se garantizan gracias a la concatenación de conceptos. Literatura es entonces combinaciones retóricas que replican combinaciones mentales (sicográficas). Para Lezama Dios es poesía, vale decir metáfora, imagen; pero imagen preservada por la comunidad que sostiene la cultura. Es a esa instancia donde tanto Borges como Lezama acuden para transformar la literatura y su manera de entenderla. Ése es el "curso délfico" lezamiano pero conformado con los pobladores del planeta. Ésa es la inmensa biblioteca 
circular borgeana donde cada palabra, cada idea o combinación imaginada ya ha sido prevista y él se la ha imaginado.

La jerarquización del registro de memoria en ambos escritores se sitúa por encima de la información sensorial para conseguir un fundamento mítico. La ficción de racionalidad es el mecanismo por el que los autores prosiguen para presentar su configuración fictiva como real y destronar el realismo, ya sea mágico, ya sea modernista. Respecto al peso de la memoria en la configuración de un modelo del universo en Lezama nos interesa considerar la opinión de Bejel. El crítico coincide con Eloisa Lezama Lima en cuanto a la creación de una cosmogonía poética para explicar el universo, pero nos da un análisis menos optimista que el de Shaw. Bejel hace depender el resultado del sistema lezamiano del periodo histórico de un grupo humano y de la recepción del individuo. Dice Bejel: "Lezama... desarrolla una visión teológica global basada en un elaborado concepto de la imagen. El paisaje constituye una imagen en el grupo humano que lo habita, y para que esa unidad llegue a adquirir un sentido, logre formar una cultura, tiene que ser interpretada por el sujeto, por el hombre" ("Cultura e historia” 244). De esta manera, Bejel traslada el análisis a la fenomenología y la recepción.

Es en este plano donde nuestros autores se sienten con el poder de transformar la visión del universo desde su entorno humano, desde el telos circundante y circunstancial. Ellos le entregan a ese entorno una visión creada desde la memoria y articulada a partir de reinventar las viejas metáforas o redefinir el estatuto de los textos literarios. Bejel se encarga de presentar esta perspectiva del uso de la memoria en Lezama desde el receptor: “[. . .] es el proceso de la memoria metafórica el que le da al hombre y a su cultura una 
visión de su trayectoria en el tiempo" (244). La perspectiva nemónica, que jerarquiza el contenido de la memoria con respecto a la lectura de la realidad, es fundamental para entender las poéticas tanto de Borges como de Lezama. Cuando se dice que la cultura (experiencia) de Borges y de Lezama es libresca, se debe entender nemónica, ya que los libros para estos autores son recreados por sus propias lecturas e imaginación.

En la isotopía de los textos estos elementos se demuestran mediante un alejamiento de la inmediatez como he señalado y el suministro de claves desautomatizadoras que son enviadas al plano mítico (mitere: enviar) en un acto intencional. Los textos de los autores que nos ocupan tienen sus referentes en la cultura metafórica, en la memoria literaria, más que en el dato histórico o en la descripción de una realidad comprobable, de ahí que Cortázar vea en los personajes de Paradiso a arquetipos en lugar de tipos literarios (136). En varios momentos de la obra lezamiana, notamos el uso prolijo de vocablos pertenecientes al ámbito urbano o natural. Siempre son elementos ordinarios elevados a categoría estética por lo inaudito de la metáfora y su concatenación.

En "Inalcanzable vuelve" tenemos la imagen del árbol, pero es un árbol fenomenológico más que un árbol físico. Lezama nos anuncia: "El árbol no termina/ el aire le llena su lenguaje" (11-12), (Poesía 333); y hasta aquí, aún nos sugiere un árbol a los antojos del viento, aunque ya trasladado a la semiótica a través del signante "lenguaje"; pero luego se separa definitivamente del uso figurativo, para acudir al árbol cultural o arquetípico:

$$
[\ldots \ldots \ldots \ldots \ldots]
$$

En el espejo del tronco 
una amarilla ave de cetrería

tolera al ave blanca masticando la nieve.

Al pie del árbol, juramentos

las tropas otomanas colocan arañas de rocío

sobre el blanco lomo de los corceles austríacos.

Dos espejos inclinados esperando,

el tronco en la mandrágora de la imagen, (36-43)

$[\ldots \ldots \ldots \ldots \ldots$. Poesía 334)

Las claves referenciales de Lezama están tan distantes temporalmente del receptor que operan como una ruptura del sistema lógico en la mente de éste. El sistema poético desde el que escribe el autor lo lleva a ese campo de alusiones una y otra vez. Como en el método de los siete octavos de Hemingway, cada poema de Lezama refiere a un todo holográfico, y cada texto; al sistema.

En Borges, también presenciamos esa estructura donde la parte refleja el todo. Escuchemos la opinión de Jaime Alazraki refiriéndose al relato El Sur, en su libro $\underline{\text { Versiones. Inversiones. Reversiones: El espejo como modelo estructural del relato en los }}$ cuentos de Borges: "Dahlmann elige la primera de esas alternativas [civilización y barbarie], pero el país lo obligará a enfrentarse con la segunda. El primer eslabón del cuento es así una cifra del cuento todo" (31). "El Aleph," por supuesto, es otro ejemplo donde el todo es contenido en un punto material. Todo el universo es contenido en un punto como en su inicio, según la teoría del "big bang." Aquí volvemos a ver la idea de la parte como cifra del todo. Borges parece haber encontrado una especie de arquetipo de la 
sinécdoque y de nuevo, la idea de la semilla de Lezama, la imago, vuelve a ser sugerida en este recurso.

Un interesante juicio al respecto se encuentra en Nightglow: Borges' Poetics of Blindness, bajo el epígrafe denominado "Continuity-Disjunction." En este caso continuidad debe ser entendida como trayectoria y "Disjunction" not discontinuity; como ese hecho poético específico, esa cristalización metafórica particular, que se separa por un momento de la norma, para luego develar que su código generatriz vuelve a alimentar el arquetipo, retornando al sistema generatriz. Lo que Florence Yudin denomina "sliding polarities of his perspective" (49) es originado por la necesidad del creador de sintetizar lo antitético, de incluir en un esquema superior de pensamiento la nueva irregularidad, porque Borges "writes poems in celebration of integrality" (Yudin 6).

Esta característica nos habla de un principio filosófico de unidad. El universo, real y fictivo a la vez, nos preexiste y permea. Cada idea, cada imagen está en él y, de alguna manera, en nosotros. El artista es el hacedor, el orfebre, el iluminado capaz de descubrir esas instancias a través de la experiencia oblicua, del aleph, de lo transtelial, de la biblioteca; de esa magnifica ironía de Dios que ha dado a Borges a la vez "los libros y la noche" (Obra poética 71). Esta mencionada unidad se despliega en Lezama como su sistema poético designado a aprehender tal orden y en Borges como un cuestionamiento ontológico llevado a la sistematicidad de un escepticismo fictivo. Ambos constatan la unidad y concuerdan en desarrollar métodos para domeñarla o al menos entenderla.

Constatar esa unidad es la energía incoativa. El trabajo posterior exige hallar recursos efectivos para expresarla en sus propios términos y plasmarla en la memoria social. Las preconstrucciones simbólicas, el reciclaje de la historia, la imago como 
nemosine son factores que parten de la memoria social y se dirigen a crear, a generar memoria. La idea borgeana de que la humanidad ha escrito un sólo libro al cual añadimos páginas, encuentra su paralelo en el curso délfico lezamiano del que Editabunda habla a Cemí en Oppiano Licario: "Licario tenía el convencimiento de un conocimiento oracular en el que cada libro fuera una revelación, con eso se evita el fárrago de lecturas innecesarias en que caen los adolescentes” (426). Y párrafos más adelante concluye: “Ya ves-le dijo Editabunda-, que no es la acumulación, sino de encontrar las esencias que nos entregan la sucesión de las generaciones y algo que se pone por encima de lo generacional para dar un salto" (428).

Ahora nos queda entender en que consiste esa poética que hemos venido esbozando a través de aislados ejemplos. El propio concepto de la sección en que unimos a ambos escritores, "Los Raros", dio un poco esa pauta enumerativa que hemos seguido y nos sirvió para ilustrar la conexión, por ausencia, que existe entre un escritor y otro. Es sorprendente la cantidad de referentes recíprocos en que ambos se tocan, pero es también sumamente sintomático la falta de vínculos directos entre ambos o la declaración de influencias mutuas. Por otro lado, los estudios críticos muchas veces corren en direcciones diferentes aunque se intercepten en algún momento respecto a estilos y técnicas de Borges o Lezama, como lo son las opiniones sobre el barroco o neobarroco y su evolución posterior en ambos. De eso se trata la sección que continúa. Indagaremos minuciosamente y con apoyo del análisis textual en técnicas específicas, tópicos recurrentes, recursos composicionales y estilísticos que develen una poética de la memoria. 
2. - Poética neobarroca: macroespacialidad/microespacialidad

El capítulo sobre poética está dividido en tres secciones: "El neobarroco," "La perspectiva macroespacial y la yuxtaposición barroca," y por último, "La perspectiva microespacial y la metaforización barroca." El conjunto conforma una tipología que nos permite definir la instancia a que pertenece, según mi análisis, la poética de estos escritores. Salvando las diferencias correspondientes, veremos cómo a través de recursos composicionales, estéticos y estilísticos se crean obras que se complementan al dar un nuevo recurso expresivo a las letras hispanoamericanas. Pero además, los trabajos de Borges y Lezama otorgan una nueva visión de la cultura moderna.

La primera sección de este capítulo, "El neobarroco," discute el uso de recursos barrocos por Borges y Lezama. A primera vista, estos recursos parecen debatibles en Borges. No obstante la mayoría de la comunidad crítica acepta la posición barroca del autor al inicio de su obra. Esta idea está apoyada incluso por las propias declaraciones de Borges en el prólogo a Historia Universal de la infamia de 1935 (Obras completas 1:289). El neobarroco en Lezama es mucho más aceptado y cuenta con una mayor teorización. Sin embargo, es cierto que faltan análisis textuales de poemas específicos. Este aspecto es señalado por Mark Richard Couture en su artículo "El agua más recordada: Golden Age Poetry in Lezama's 'Ah, que tú escapes”' (21). En ambos casos se alude a lo barroco como algo intrincado y oscuro, "laberíntico," pero no al barroco como instrumento conformador de una cosmovisión poética, y mucho menos se ha hecho un inventario confiable, de los textos finales de Borges o Lezama, para emitir juicios definitivos.

"El neobarroco" refleja una visión. El sólo hecho de asumir el barroco refuerza la idea cíclica de la historia al retomar todo un periodo pasado de ésta. Se debe añadir que el 
barroco, como corriente de época, viene conjuntamente con toda una visión filosófica y un gusto por las corrientes de pensamiento que le son afines. De manera que asumir el barroco implica también asumir una posición, tomar un partido estético-filosófico. Asumir el barroco es, pues, asumir un estilo, pero también un conjunto de principios estéticos. Así, los autores que nos ocupan, no sólo recuperan el estilo y la retórica del periodo, sino, conjuntamente con ello, parte de la metafísica y la escolástica que acompañó al primer barroco, ahora como elemento fictivo.

La sección "El neobarroco," a su vez, está dividida en una breve discusión sobre la pertinencia del barroco en Borges y Lezama, y luego continúa con un breve recorrido sobre el barroco en Hispanoamérica. La segunda parte de esta sección es demostrativa. Ésta concibe un barroco externo que es compartido por ambos autores y se refiere al uso de las condensaciones, las enumeraciones caóticas, las escenas de montaje y los tópicos carnavalescos. Estos tipos de recursos barrocos son usados por Borges en "El atroz redentor Lazarus Morell" (Obras completas 1:295-300) y por Lezama en el ritual fálico de Farraluque (Paradiso 342-45). Después de revisar los recursos barrocos externos presentes en ambos autores, el estudio aborda las diferencias entre el barroco por yuxtaposición y el barroco metafórico que define la polaridad entre Borges y Lezama, entrando ya en las secciones subsiguientes. De modo que la sección "El neobarroco" se solapa de alguna manera con las secciones que le siguen.

El concepto barroco nos servirá de justificación para un análisis de poética. Extiendo los límites a recursos que pueden salirse de la conceptualización barroca como tal, pero que siempre se hallarán dentro de esa relación polar-conplementaria que he definido. El concepto nos sirve aquí de centro en torno al cual gira todo un análisis de 
cosmovisión estética. Vale la aclaración, porque no está definitivamente establecido si muchos de los recursos que hoy se consideran neobarrocos aparecieron en la literatura antes o después que el propio barroco como periodo. Por otro lado, algunos recursos usados por Borges y Lezama entran en una especie de terra incognita, y aunque ahora podamos incluirlos en esta sección, son recursos que requieren de una tipología aún no establecida.

De modo que defino un barroco externo y formal que ambos comparten, y que es al que me dedico en la sección "El neobarroco" como he mencionado; y otro barroco mucho más personal y constitutivo del discurso de cada uno, que compromete a las estructuras profundas del lenguaje. En este caso están la yuxtaposición barroca en Borges, en contraste con una metaforización barroca en Lezama. La segunda sección de este capítulo estudia precisamente lo que he denominado yuxtaposición barroca. Este recurso tiene que ver con el estilo de demostración ensayística al cual se refiere el crítico Seymour Menton (El cuento 341). La yuxtaposición barroca, usada por el narrador borgeano en las ficciones de estilo demostrativo, es un recurso pertinente y homogéneo en sus textos. Dicha yuxtaposición barroca nos permite, así mismo, definir más nítidamente la poética borgeana.

La tercera sección que complementa a la segunda, y contrasta en contenido con ella, se refiere a la metaforización barroca lezamiana. Un barroco que se da, no en la ilación sintáctica, o en la isotopía discursiva, como es el caso del barroco por yuxtaposición borgeano, sino dentro del concepto metafórico. Lo barroco en Lezama se da en forma de estadística visual, de plexos paralelos al concepto. La condensación metafórica que origina el barroco en Lezama ocurre mayormente en la polisemia del 
concepto. Esta condensación en muchos casos violenta la lógica sintáctica. El fundamento de estas dos formas de percepción y concepción estéticas, a saber la yuxtaposición barroca borgeana y la metaforización barroca lezamiana, se encuentra en la perspectiva macroespacial en Borges y en la perspectiva microespacial en Lezama. Revisaré estos modos de focalización mediante el análisis de textos.

Según lo que va dicho, se entiende que evaluaré dos tipos de instancias de lo barroco. La primera instancia, referida a las condensaciones y enumeraciones caóticas, se encuentra en ambos autores y se da en el texto a nivel externo. Este recurso barroco no altera la lógica sintáctica y es de orden alegórico. Es un recurso mucho más común y osado en Lezama que en Borges. La segunda instancia no es común a ambos autores, sino polar. Marca la diferencia estilística entre Borges y Lezama a nivel textual, a la vez que desvela los recursos de verosimilitud y perspectiva en ambos estilos. De cualquier manera, el barroco en ambos autores es un andamiaje ancilar que sirve para llevar a cabo un proyecto estético mayor.

a. - El neobarroco.

La relación de Borges y Lezama con respecto al barroco es problemática, como lo es la relación de éstos con respecto al Boom, elemento este último, que hemos esbozado en la introducción. Esta problematicidad se puede constatar con algunos ejemplos. Según Mark Richard Couture en el estudio ya citado: “In Borges' trajectory as a poet, there is an increasing push for simplicity, something that may be considered a swerve away from baroque" (Secret Accomplices 87$)$. Esta opinión es semejante a la de César Augusto Salgado (65) que ve un alejamiento del barroco en Borges y un acercamiento a una 
actitud más panteísta. Por su parte, en su artículo "Borges o la ambivalencia como sistema," Alazraki asegura que:

Enquevedizado hasta los huesos en su juventud, saldrá del barroco por las puertas que le abrían las magias parciales del Quijote, pero el barroco le había enseñado las trampas, pasadizos y secretas cámaras del idoma. Me inclino a creer que ese substrato barroco no desaparece del todo. Forma un sedimento, una rienda de las muchas que maneja Borges y que fijan el curso y tenor de su prosa. (19)

Revisando aún la opinión de Mark Richard Couture, más adelante en su tesis nos hace saber que: "although [. . .] the baroque is central to each of these writers [. . .]. It is my argument that we can read in Lezama's and Borges's comments on Joyce's novels a debate in which Borges adopts a position antagonistic to the baroque 'monstrosities' of James Joyce's work while Lezama articulates a positive theory of the joycean novel" (Secret Accomplices 261). Hasta ahora tenemos que el barroco es esencial a Borges y a Lezama, aunque es una idea común de la crítica, que Borges parece evolucionar a una posición alejada del barroco. Cuánto de barroco es central a ambos y hasta cuándo esto es válido en la obra de Borges, sigue siendo en mi opinión un problema a definir.

En las citas anteriores el crítico explicaba la separación de Borges de ese barroco complejo a formas más simples de expresión. Luego nos mostraba una disyunción entre Borges y Lezama en cuanto a sus opiniones sobre la obra de Joyce. Se pudiera colegir que Lezama no evoluciona en su barroco. Sin embargo, otras opiniones nos asegurarían lo contrario. En un artículo que relaciona el poema "Ah, que tu escapes" de Lezama, con la literatura del siglo de oro, Mark Richard Couture comenta sobre distintos criterios en 
la evolución barroca de éste. La cita en sí se refiere a una aseveración que proviene del crítico cubano Roberto Fernández Retamar, y se inserta en una revisión sobre la índole de los estudios a que ha sido sometida la obra de Lezama. El crítico asevera: "Fernández Retamar traces the development of Lezama's verse from the barroco exhuberance of Muerte de Narciso to the more metaphysical ruminations of Lezama's later colections" (“El agua" 21).

Según la opinión de Roberto Fernández Retamar, analizada por Mark Richard Couture, Lezama ha transitado de una exuberancia barroca, hacia reflexiones más metafísicas (la traducción es mía). Es decir, que se asume una evolución en el estilo lezamiano respecto a sus códigos estéticos. Si observamos la cantidad de escenas de montajes y situaciones carnavalescas que existen en Paradiso y Oppiano Licario, como veremos detenidamente en su momento, nos damos cuenta de que el barroco lezamiano ha evolucionado hacia un barroco aún más lezamiano. Semejante opinión ha expresado de Borges el crítico César Augusto Salgado, cuando apunta que el autor de Ficciones ha operado una evolución hacia "the classical, pantheistic view of literature of his mature years" (65).

Por supuesto que en ambos casos ha ocurrido una evolución, siempre ocurre. Pero algunos recursos barrocos persisten en los textos últimos de Borges y Lezama. Aún en la etapa de madurez de estos autores el barroco trasciende como una voz narrativa ya asentada. La perspectiva periodicista permea muchas de estas formas de crítica, que proponen modelos evolucionistas preconcebidos. Estos modelos aplicados a unos autores, son después transportados a otros, como corrientes o formas de pensamientos de la crítica propia. El entendimiento que tenemos de las obras de Borges y Lezama, 
después de las explicaciones teóricas y entrevistas aclaratorias, propiciadas por estos autores, nos crea una ilusión de evolución en ellos. Creo que esta idea de evolución es falsa y quizás hasta entregada (elaborada), a exprofeso, por los autores en cuestión. Si Lezama hubiera comenzado su trayectoria literaria con Oppiano Licario y terminado con Muerte de Narciso se podría decir lo mismo de su evolución hacia formas más metafísicas y menos barrocas, de hecho, esa es la indagación de Narciso. Otro tanto se puede decir de Borges, si hubiera comenzado su trayectoria con Los conjurados o $\underline{\mathrm{La}}$ cifra y hubiera terminado con Fervor de Buenos Aires o La luna de enfrente.

Hay más de ambigüedad aún en esta línea de crítica. Contrario a muchas opiniones que niegan el barroco en Borges, Sarduy asevera que éste abusa del barroco y sus recursos paródicos, a lo cual le ha llamado "demasiado célebre artificio Borgesco" (cit. en Levine 104). Virgilio Piñera con su calificativo tantálico ("Nota" 44.), declara el barroco de Borges (y Lezama) y lo acusa de no tener referentes reales sustanciales que le den acicate a la obra. La opiniones sobre Borges y Lezama en unas ocasiones se contradicen, como es el caso de Virgilio Piñera y Cintio Vitier, en los ejemplo revisados sobre criollismo y enajenación; en otras ocasiones, las opiniones igualan a Borges y Lezama en distintas épocas de la crítica, como demuestran las citas de Mark Richard Couture referida a la opinión de Roberto Fernández Retamar y la cita de César Augusto Salgado, sobre las evoluciones respectivas.

Como se puede ver, la pertinencia del barroco en Borges y Lezama es sumamente problemática y llena de matices. Siendo el interés de este trabajo la poética de ambos autores y no el delineamiento del barroco como tal, opto por una revisión útil al propósito. En síntesis, mi hipótesis es que el barroco en Borges y Lezama viene a servir 
ancilarmente a una poética autorreferencial y orgánica; es un recurso fictivo que no se puede analizar desde la periodización y los modos de la literatura regional. Es necesaria una aproximación diferente, para poder discriminar estas características y arrojar luz al proceso de conocimiento infinito que implica la cuestión.

La discusión sobre el barroco, en las últimas décadas, se ha tornado insistente y polémica. Un texto relevante es el prólogo de Alejo Carpentier a El reino de este mundo, que manifiesta la idea de que Latinoamérica es el continente donde el barroco encuentra su consagración telúrica (y por extensión del realismo mágico). Para Carpentier, Latinoamérica es ese lugar donde el telurismo exige de un estilo auténticamente barroco para expresarse. Las propias imágenes que usa el autor en el capítulo "Las cabezas de cera," donde se yuxtaponen diversas imágenes de cabezas que van desde las de un caballo o un toro, hasta las fotografías del rey de Francia colgadas de un alambre (El reino 9-11), son una explicación práctica de los métodos de yuxtaposición barroca usados en el texto. La circunstancia que encuentra Carpentier en la ciudad de Cabo Francés es una realidad propicia a esa concatenación cinematográfica de símbolos.

Otros autores como Lezama sostienen que el barroco ha existido siempre y en todas partes del globo. Lo ven más como una opción de expresión que América, sin embargo, ha potenciado hasta sus últimos límites (Eloisa Lezama Lima, Introducción 5660). Aunque la opinión de Lezama es cercana a la de Carpentier en cierto sentido, Lezama tiene un acercamiento más metafísico y menos antropológico que Carpentier. El autor de $\underline{\text { Paradiso }}$ deja ver en su uso del barroco una intencionalidad poética que dialoga con la ontología. Además, el elemento plástico del barroco en Carpentier tiene raíces primitivistas, en oposición al barroco de Lezama donde el elemento plástico del barroco 
es mucho más helenístico y carnavalesco. La indagación en las imágenes de la sexualidad, en Lezama, otorgan un carácter postmodernista a su barroco y han hallado continuidad en muchos textos de Reinaldo Arenas y Severo Sarduy.

Debo agregar que Lezama no se considera barroco, si se entiende éste como un hermetismo innecesario y obsesivo, más bien considera el barroco como una auténtica forma de expresión y aprehensión de la realidad. Para Lezama, el barroco, es descubrir esencias liminales de la realidad física y social. Su mirada recupera la realidad de manera barroca. Obsérvese lo insólito de la percepción lezamiana y sus conexiones culturales sobre el barroco en Cuba:

En el siglo XVIII el artesanado se adelanta en los trabajos de madera, ya en la rubia caoba o el verde viejo, tendencioso a una oscuridad azulenca, del cedro. Es el barroco cóncavo y jesuita de Borromini, que lo mismo se abullona y curva en una lasca de la piedra lateral de la Catedral habanera, o en una cómoda del palacio brunet o en un guardacasullas y estolas de la iglesia de la Merced (La materia artizada 133).

El barroco es una herramienta útil a la circunstancia que lo rodea, y se conforma a partir de una observación selectiva. Éste le permite encontrar los rasgos pertinentes de un estilo, en objetos disímiles y prácticamente inasociables por una mirada común.

Dicho proceso de percepción encuentra su continuidad en una síntesis expresiva que también elabora en forma barroca, al respecto ha dicho Fina García Marruz: "Lezama es hermético, no gongorino, y tiene que serlo porque intentó temas que la poesía contemporánea no procura" (118). En este sentido, el barroco para Lezama arroja condensaciones metafóricas a la semiótica social y articula relaciones entre el ser y Dios. 
Por eso, pienso que aunque Lezama incluya mucho de la visión cultural del barroco en sus textos sobre el arte y en sus ensayos críticos, en su práctica, el barroco es más una forma de replicar lo que él entiende por realidad a nivel de la imagen. La perspectiva en Lezama hace que el uso barroco opere en el signo lingüístico. Esta forma se da sobre todo en su poesía. Mientras que en Carpentier opera mayormente en la estructura externa y a nivel simbólico. Quizás esta diferencia esté dada por el hecho de que Carpentier es básicamente narrador (relator), y Lezama poeta (augur).

Cintio Vitier compara el barroquismo lezamiano con el precedente barroquismo cubano: "Si Espejo de paciencia encuentra el contraste barroco de lo mitológico y lo indígena, Muerte de Narciso se sitúa en la naturaleza mítica de abierta encarnación barroca" ("La poesía de Lezama Lima" 47). Posteriormente el crítico hace un comentario sobre el mismo poema donde alude a las potencialidades que encuentra Lezama en el método barroco: "La libertad y apertura de la palabra de Lezama en este poema, nos avisaban ya oscuramente sobre un barroquismo que no era el previsible" (47). Cintio Vitier habla de un barroquismo "inderivable" (47) en la escritura de Muerte de Narciso. En Lezama el barroco está íntimamente ligado a su intención de renovación formal. Como estilo el barroco permite también la autoreferencialidad, lo cual es característica primordial en la estética lezamiana.

Las opiniones sobre qué es el barroco para los latinoamericanos ha tenido también distintos tintes y posiciones desde el punto de vista político-social. Si la opinión de Carpentier se basa en una perspectiva cultural comparativa, que mira a Europa y trata de hacerla entender; la posición de González Echevarría le da al barroco cierto carácter clasista. El crítico considera el barroco como una corriente marginal, desterrada de 
alguna manera del "centro" estético en Europa y por ende, propia de Latinoamérica que se considera marginal de origen. Así lo apunta, citando a su vez, a Lezama: "Tiene razón Lezama cuando ve en el barroco el primer movimiento artístico americano. Para el americano, el barroco [. . . ] es un arte marginal como él" (64).

Simplificando quizás demasiado las posiciones de Carpentier, Lezama y Borges sobre ese nuevo (neo)barroco, nacido ahora en el también nuevo continente, yo me atrevería a afirmar que Carpentier trata de explicar a Europa por qué América Latina es barroca. Su recorrido continental y su mirada étnica así lo demuestran. Lezama está convencido de que el barroco es su pertenencia, su lengua. Lezama no parte de una intención informativa, no le interesa explicarse porque sabe que es imposible entender, sólo propone que observen, que disfruten, o en todo caso, prefiere esconder.

Borges, al igual que Lezama, invierte el sentido de la conquista. Su barroco va de aquí hacia allá, pero se centra en demostrar el fallo de los medios de explicación, por tanto se burla de tal lógica. Es decir, Carpentier explica, Lezama exhibe, Borges parodia. Pero esta contrarreforma barroca en Borges y Lezama viene a su vez de la Europa de Cervantes, Góngora y Quevedo, por lo que el movimiento es elíptico. Es un movimiento donde Pierre Menard (Borges) recrea y juega a la literatura. Margo Glantz, revisando la intertextualidad en las ficciones de Borges, expresa: "(Estas historias) son el irresponsable juego de un tímido que no se animó a escribir cuentos y que se distrajo en falsear y tergiversar (sin justificación estética alguna vez) ajenas historias." [sic] (Glantz 21, paréntesis del autor).

Sarduy, por otra parte, desarrolló su teoría del neobarroco otorgándole cierta estructuración y una temporalidad postmoderna, por su vínculo con las ciencias y el 
travestismo. En las teorizaciones de Sarduy el barroco se asocia a la teoría de la carnavalización de Bajtín y tiene un componente plástico y exótico importante. Sarduy también maneja en sus escritos recursos del barroco como la elipsis, la hipálage, el oximoron, la enumeración caótica, la parodia y los recursos de yuxtaposición cinematográfica que resultan sumamente relevantes al propósito de este estudio.

Esta teorización del barroco nos ha propiciado una nueva herramienta analítica, para entender mejor ciertos aspectos de los textos de Borges y Lezama. La siguiente cita de Mark Richard Couture nos sirve de puente con las teorizaciones de Sarduy sobre el neobarroco: "Instead of merely reacting to generational pressures, Borges and Lezama are seeing in these Golden Age poets a cluster of concerns that mirrors their own. It is this sort of literary coincidence that leads a writer like Severo Sarduy to formulate his theory of the neo-baroque" (Secret Accomplices 291). La descripción del barroco como método de ficción pura, desprendida de las necesidades causales y miméticas, es un gran acierto de Sarduy.

Con esta autonomía barroca, Sarduy aporta un elemento nuevo a su interpretación, que se opone de alguna manera a la idea de González Echevarría. Para Sarduy, el barroco se caracteriza por el camuflaje, la decoración, el exceso, el exordio. Estos elementos se encuentran originalmente, incluso, en la naturaleza, y existen independientes al instinto de conservación o a una necesidad de reproducción. Es decir, para Sarduy, el barroco es puramente fictivo, artístico y existe en todas las expresiones de la realidad. Cito a Sarduy, al final de esta cita Sarduy incluye una referencia a la obra de Roger Caillois, Méduse et Cie: 
En definitiva, lo letal no es a su vez más que una forma extrema, el exceso del despilfarro de sí mismo, y si se tiene en cuenta que el mimetismo animal es inútil y no representa más que un deseo irrefrenable de gasto, de lujo peligroso, de fastuosidad cromática [ . . ] tendremos que aceptar, al proyectar este deseo de barroco en la conducta humana, que el travesti confirma sólo 'que existe en el mundo vivo una ley de disfrazamiento puro [.. . ] que no puede reducirse a ninguna necesidad biológica derivada de la competencia entre las especies o de la selección natural.' (La simulación 16$)^{21}$

Sarduy desarticula por primera vez el barroco de la causa telúrica o de cualquier otro tipo de causa en la crítica hispanoamericana. Niega con esta demostración que exista una causa que produzca el barroco y lo convierte, a su vez, en causa absoluta que genera el efecto estético. El barroco es pura ficción, puro juego consustancial al arte. Esta aproximación esteticista que desconoce la inmediatez como substrato y jerarquiza la ficción pura, nos acerca a las ideas de los autores en cuestión en este estudio.

Borges dice, en el prólogo de 1954 a Historia universal de la infamia, que el barroco es la parte final, sobredecorada de cualquier arte, ese momento en que "éste exhibe y dilapida sus medios" (Obras completas 1:291). No me compete decidir si "final" para Borges significa último o ulterior. Sólo quiero llamar la atención sobre los elementos de dilapidación, exhibición de elocuencia, ficción metaliteraria, yuxtaposición y parodia que Borges se esmera en presentar en sus obras de manera explícita. Sarduy, en $\underline{\text { Notas a las Notas a las Notas... a propósito de Manuel Puig, y refiriéndose a } \underline{\mathrm{H}} \text {. Bustos }}$ Domecq: Seis problemas para don Isidro Parodi (1942), comenta: "Borges supone un 
corpus conocido, asimilado por el pensamiento común del momento -situaciones caballerescas o policíacas-, del cual la novela es la reiteración elogiosa y burlesca" (555). Según Sarduy, Borges utiliza aquí la parodia como recurso barroco y de ahí tomó el propio Sarduy soluciones expresivas para su escritura.

Borges no esconde sus recursos. De hecho, uno de los aciertos artísticos de sus textos es precisamente la transparencia y evidencia de la demostración ensayística. El uso de la literatura y la crítica para crear ficción prueba que todo ese substrato cultural no tiene otra función que la del propio goce estético. De esta posición se deduce que la propia lógica del ser humano no tiene consecuencia ulterior que la del goce de esa capacidad ilusoria. En referencia a esa finalidad estética a que fluye toda forma de creación humana Borges ha dicho, refiriéndose esta vez a la filosofía: "Las invenciones de la filosofía no son menos fantásticas que las del arte" (Obras completas 2:47). Semejantes opiniones se encuentran en textos de Borges sobre la Biblia, la historia, la religión y otras formas de pensamiento.

Otro elemento en apoyo al sostenido afán de Borges por asumir una estética neobarroca, como la formulada por Sarduy, es su distorsionada y metafísica alusión al travestismo, visto a través del desdoblaje del propio “yo.” La relación lúdica que el autor establece entre su identidad y su escritura es un motivo recurrente en sus textos. La forma extrañada con que Borges se mira frente a sí, más que un recurso fictivo, es una recurrencia que se deposita (encuentra) en varios niveles textuales en la obra del autor. Aquí entran en juego la obsesión con los espejos como símbolo (o mythoi), e incluso, la estructura especular en sus obras como asentamiento estrustural de dicho desdoblamiento (Alazraki, Critical Essays 10). 
En "Al espejo" (o a Borges), el autor nos entrega parte de la clave: “Por qué duplicas, misterioso hermano,/ el menor movimiento de mi mano?/ ¿Por qué en la sombra el súbito reflejo?/ Eres el otro yo de que habla el griego/ y acechas desde siempre. [. . .]/. (1-4) (Obras completas 2:510). La pregunta va más allá del espejo como objeto. Borges la pone en este poema en una dicotomía dada por los conceptos ceguera/reflejo-eterno. Es lógico pensar que Borges ni siquiera se plantea la interrogante frente al espejo, sino que observa desde su interior a su otro yo.

Giovanna Bartucci ha realizado estudios psicoanalíticos sobre el desdoblamiento entre el yo de la escritura borgeano y el yo real. En Borges: A Realidade da Contrução: Literatura e Psicanálise, Bartucci expone el carácter gnoseológico de este aspecto de la escritura borgeana, al decir, refiriéndose al propio autor: “[. . .] há aqueles, entretano, para quem podemos considerar o processo da escrita como uma forma de desconhecimento do mesmo, que tem como objetivo ser instrumento de maior conhecimento de si” (114). La indagación de Borges ante sí mismo es también una clave de la indagación barroca. El sujeto es y no es. De esta manera el duplo sirve de camuflaje, portando parte de la carga semántica del concepto Borges.

Pero la carga especular también se refiere al peso de la tradición, de la herencia, de una eterna mirada que no cesa y que se asocia, por su sistematicidad, con los arquetipos literarios. A este respecto dice la autora:

No entanto, ao utilizar-se da figura do duplo, aquí entendida como un elemento operador com a função de mediador "entre" o mesmo "e" o uotro, Borges criou um dispositivo para si mesmo que permitiu, sim, que o autor pudesse, para além de apagar a imagen paterna, incorporar seus 
antepassados, heranças familiares e literárias, de modo a establecer um diálogo criador com sua propia escritura ("Entre o mesmo e o duplo, inscreve-se a alteridade. Psicanálise freudiana e escritura borgiana" 384).

En este proceso de anagnórisis del "yo" borgeano, están la construcción y la deconstrucción de esa identidad, como dos caras que viajan simultáneamente. El desdoblarse en el "otro" es una característica peculiar del sujeto barroco americano. Debemos entender la focalización y re-asimilación que Borges y Lezama hacen de la cultura occidental, como un proceso de negación y aceptación, desde el cual nace un sentido de identidad.

James López en su artículo titulado "El Barroco americano en el modernismo: el pensamiento estético de Martí y Herrera y Reissig," plantea que la psicología barroca ha estado "bajo la influencia directa del psicoanálisis" (9). De esta influencia se infiere un carácter "escindido [. . .] del sujeto en el barroquismo americano" (7). El desdoblaje que muestra Borges en la estructura de sus textos, en su identidad cultural y en los temas explícitos sobre su otro yo, muestran una indagación sobre la identidad del sujeto desde el punto de vista de esta ideología barroca. Asimismo, el prisma borgeano se pudiera ver como una dispersión del yo, asociado a ese escepticismo donde la identidad es también cuestionada, aspecto al que me dedicaré más adelante.

En la discusión sobre el barroco americano hay que tener en cuenta estas tendencias, por cuanto aportan en términos de identidad textual y lo que significan desde el punto de vista de la aculturación. Según López, en el barroco americano "el lenguaje ha renunciado a toda pretensión racionalista (demostrativa), la identidad es reemplazada por la intertextualidad" (10). Estas ideas están vinculadas a las novelas de lenguaje y a la 
creación de una identidad textual por el sujeto neobarroco americano; pero también guardan relación con la ficción de racionalidad. Borges y Lezama, sin abandonar el racionalismo como recurso fictivo, recuperan del barroco estos rasgos, en los que lectura equivale a percepción, y escritura a creación fáctica.

No es interés de este estudio, reeditar la historia de la discusión sobre el barroco en América Latina más allá de los elementos aportados. Opino que el barroco, al igual que cualquier otra estética, puede darse en distintas épocas y reaparecer una y otra vez con distintos matices, de manera que la división periódica, tan socorrida hasta ahora pudiera ser suplantada por una división de otro carácter. En este sentido he planteado, al inicio de este estudio, que considero acertada la opinión de Claudio Guillén cuando dice: "La vieja noción de período como concepto que aspira a coincidir plenamente con un segmento de tiempo y que de tal suerte constituye una unidad singular de la historia literaria, queda descartada [. . . ] la noción de período como a la vez continente y contenido ya no es aceptable" (Teorías 124).

Lo importante aquí es definir cómo Borges y Lezama se sirvieron de los recursos barrocos para desarrollar sus poéticas, y demostrar su uso específico en los textos, buscando la semejanza o polaridad entre ambos autores. Esta sección se propone explicar qué se entiende por barroco al referirse a los procedimientos de estos escritores, incluso a pesar de que en algunos casos, uno u otro se haya defendido de la calificación barroca de su estilo. Es conocido que Borges se anuncia barroco en cierto momento de su carrera y también se anuncia curado de ese barroco inicial (Borges el memorioso 79). Comparto la opinión expresada por Seymour Menton en su artículo "Jorge Luis Borges, Magic 
Realist" referida a Borges de que "an author's words about his own works may not always be taken at face value" (411).

Los recursos barrocos están presentes en los textos de Borges, a pesar de anunciarse éste curado del barroco. César Augusto Salgado discute la opinión contradictoria de Borges acerca de la obra de Joyce y asevera que una de esas opiniones es la ironía de la otra. Posteriormente el crítico agrega: "This irony could be seen as the result of Borges's well-documented evolution from the expressionist, baroque-oriented, aesthetic ideology of ultraísmo in his youth to the classical, pantheistic view of literature of his mature years" (65). En mi opinión, el deslinde debe ser hecho en la asociación entre el expresionismo, el barroco y el ultraísmo. Rescatando lo dicho por Cintio Vitier sobre Lezama acerca de su barroco "inderivable", pienso que Borges evoluciona de una forma que incluye el barroco, a otra que también incorpora sus elementos, pero desde otra perspectiva. Dicho sea además, que esa visión panteísta en la literatura es ciertamente uno de los temas comunes a ambos escritores, lo que también discutiremos en este estudio.

Asumir el barroco como estilo es asumir los principios filosóficos y estéticos en que éste se asienta. Esta es otra vertiente, algo solapada, que se percibe en las preferencias temáticas de los autores en cuestión. No sostengo que Borges y Lezama se crean escolásticos, filosóficamente hablando, o barrocos en un sentido fundamentalista. Sí pienso que encontraron en esa estética y en el gran substrato de obras de pensamiento y estudios que le da sustento, una materia prima muy atractiva para reactivar los modos de escribir de la época que les tocó vivir. El barroco también da cierta libertad esteticista al replegarse en sus propios medios y reflejarse en sí mismo. 
En estos escritores se da lo acumulativo, la referencia a la existencia como algo ilusorio, el estoicismo, que en este caso se disfraza de un nuevo tipo de "recogimiento" bibliotecario, pudiéramos decir. Existe una conciencia de crisis en Borges y Lezama que si bien está desplazada a preocupaciones de renovación estética, aún se expresa como crisis y es un signo barroco. Pero en ese esfuerzo por no reflejar la realidad, sino por reflejar cómo percibe nuestra mente esa realidad, Borges y Lezama se acercan más a filosofías idealistas como la de Berkeley y Espinosa y a los recursos demostrativos Cartesianos.

El vocablo neobarroco tiene, entre otras connotaciones, la temporal. El beneficio de la filosofía posterior a la escolástica en sí, en este caso la de Berkeley, con su idea de que la mente es la única realidad y con la disolución de la contradicción entre la ciencia y el pensamiento religioso, sirven de fundamento a esa ilusión literaria que crean los textos de Borges y Lezama. Ambos encuentran en estos filósofos el balance de demostración retórica y de pensamiento científico (empírico) agradable al gusto de esta era tecnológica. Este balance conjuga por un lado, el pensamiento idealista y la fe religiosa, y por otro, la demostración lógica, en la cual se podría incorporar a Descartes y la ciencia. En esta jerarquización de la materialidad del lenguaje, el barroco de Borges y Lezama expande el imaginario cosmovisivo del barroco clásico.

El barroco en los autores que nos ocupan se nutre también del surrealismo y de toda su carga onírica correspondiente. Como nos advierte Giovanna Bartucci sobre Borges: "Seu principal objetivo é confundir as fronteiras entre realidade e sonho, entre realidade e ficção" (Borges: A Realidade da Construção 101). De este modo, el barroco como estética integradora se convierte en neobarroco como recurso actualizado. Según 
Margo Glantz, la idea de la vida como sueño es una idea central en El Hacedor (18). Esta idea que se "repite obsesivamente," combina en Borges los sueños, la Alquimia, la Cábala y la Gnosis: “Alquimia, Cábala, Gnosis, Astrología, están en la base de muchos de los cuentos y poemas de Borges y van de la mano con las filosofías de los autores que le preocupan: Platón, Plotino, Espinosa y Berkeley” (Glantz 18). Borges lograr crear ficción a partir de las interpretaciones culturales de las épocas.

La época barroca fue sin duda rica en sustancia y materia fictiva, al verse obligada a crear una conceptualización de lenguaje que respondiera a la fricción transicional del pensamiento teocéntrico al pensamiento antropocéntrico. La relación realidad-religión es un aspecto esencial en el barroco de Lezama. Si Borges está más cerca del idealismo de Berkeley, Lezama exhibe un estilo que combina la síntesis de la escritura religiosa española con lo enrevesado de la arquitectura barroca. El barroco llevó elementos retóricos a un alto grado de perfección y sutileza sin lugar a dudas. Lezama parece atraído por ese lustre retórico que el barroco da a la palabra y se permite coquetear con lo sinuoso del estilo para expresarse libremente.

Lezama necesita y gusta de esconder ciertas claves. El barroco en Lezama codifica. Según Antón Arrufat su barroquismo "fue parte de su naturalidad" (152). Continúa diciendo el crítico sobre el estilo lezamiano: "El punto central de la obra (o de la personalidad) de Lezama consistía en considerar la realidad (el mundo) como una vasta red de analogías [. . .]. El barroco alude. Es perifrástico. Un objeto lo conduce a otro: son en el fondo análogos. El mundo es una enorme galerías de espejos frente a otros espejos" (150-51, paréntesis del autor). El barroco en Lezama es una expresión de poder, es su triunfo frente a las inmanencias represivas de su circunstancia. 
Borges, sin embargo, muestra una evolución barroca peculiar; pero evolución en Borges es también movimiento pendular, ida y regreso. Si al inicio de su escritura el barroco se manifiesta con sus recursos más externos y formales como son el montaje, las condensaciones, los recursos paródicos; al final de su carrera vemos una aproximación al manierismo. El barroco se ha retirado a lo interior de la estructura textual. Los recursos retóricos donde la demostración lógica se exhibía, han pasado del ricercare a la fuga, al ricorsi, y Borges pasa de una metaliteratura a una especie de "autometaliteratura."

Lezama y Borges están condensados en la obra de Sarduy o, para expresarlo de otra manera, la visión de Sarduy sobre estos escritores nos permite visualizar empatías relevantes en ellos. Para Sarduy, el barroco en la literatura es derroche, parodia (El barroco 176) y en su opinión es tanto una característica de la escritura de Borges como de la escritura de Lezama. Como nos dice Suzanne Jill Levine: "Sarduy nos explica que la elipsis gongorina es el mecanismo clave de esta literatura auto-crítica que reconoce que es anti-denotativa, y por consiguiente connotativa" (100). Dicho derroche denotativo es una característica esencial que veo en las obras de los autores que investiga este estudio.

El alejamiento del referente inmediato expuesto en Los Raros como peculiaridad de la literatura de Borges y Lezama, con respecto a la mayoría de los escritores coetáneos a ellos, es una consecuencia de la jerarquización de la connotación por encima de la denotación. En palabras de Suzanne Jill Levine: "Sarduy tanto como Borges nos enseña repetidamente que no hay realidad fuera del texto; captar o pretender captar una realidad extra-textual es inútil, no lleva a ningún lado" (96). Esta idea está en consonancia con la opinión sarduyana sobre la inutilidad del mimetismo, cara también a Borges. 
Los procedimientos barrocos usados por Borges guardan sorprendente similitud con los usados por Sarduy. En las páginas que siguen me dedicaré a demostrar estas pautas barrocas en la poética de Borges aisladamente, y luego pasaré a demostrarlas en la poética de Lezama. Dando un cambio al estilo de demostración paralela usado hasta ahora, seguirá el desarrollo de los aspectos del barroco externo en los textos de cada autor por separado, y luego se presenta una discusión de la yuxtaposicion barroca en Borges seguida de la metaforización barroca en Lezama.

Uno de los procedimientos barrocos detectados en los textos del primer Borges, lo comparte Sarduy. Varios autores han visto esta característica como un recurso bien aprendido por Borges. Saúl Yurkievich, en su artículo "Jorge Luis Borges y Ramón Gómez de la Serna: el reflejo recíproco," muestra cómo las enumeraciones caóticas son un proceso que va hacia la comprehensión de la totalidad: "Para metaforizar la inconmesurable vastedad, la inagotable diversidad del universo aprehendido como simultaneidad de singularidades, [Borges] recure a la única figura apta: la enumeración caótica" (81).

A esto también se refiere Suzanne Jill Levine en su artículo. El procedimiento en cuestión es lo que Sarduy denomina "condensación" y Borges "la brusca solución de continuidad" y también "la reducción de la vida entera de un hombre en dos o tres escenas" (102). El estudio explica las características de este recurso en ambos escritores, a partir de la visión sarduyana. Nos dice Suzanne Jill Levine:

Sarduy agrega que 'el campo ideal de la condensación es la superposición cinematográfica'. Curiosamente, Borges, en un cuento de $\underline{\text { Historia }}$ Universal, menciona que el método narrativo que él prefiere y usa es el de 
'cierto director cinematográfico' que 'procede por imágenes discontinuas' (brusca solución de continuidad) (p. 68). (103)

Suzanne Jill Levine procede explicando los dos tipos de superposiciones, a saber: la condensación sincrónica (superposición de dos imágenes en una sola) y la condensación diacrónica (103) donde se da "la superposición de varias secuencias, que se funden en una sola unidad del discurso en la memoria del espectador" (103).

El estudio divide el recurso de las superposiciones en superposición sincrónica y superposición diacrónica. La primera, a nivel del lenguaje, se da "por medio de figuras retóricas barrocas como "hypallage", "oxymoron", metáforas paradójicas" (103); y plantea que Borges las usa en el cuento "El atroz redentor Lazarus Morell." Por otro lado, la superposición diacrónica sería la manera en que la historia es contada: “Ambos Sarduy y Borges reducen las 'biografías' de sus personajes a pocas escenas yuxtapuestas sintéticamente" (104), "función de reducción" a la que Sarduy ha llamado "demasiado célebre artificio borgesco" (104).

Ante estas demostraciones de Suzanne Jill Levine nos encotramos con recursos barrocos convencionales en la obra de Borges. Esta comparación se basa en coincidencias "explícitas" (91) entre Historia universal de la infamia y "Teatro lírico de muñecas" de $\underline{\text { Cobra. }}$ El ensayo demuestra cómo Borges en "la introducción a la historia infame de "la Viuda Ching, Pirata"" (98) muestra un travestismo que "nos podía hacer sospechar, si no supiéramos fechas de publicación que Borges había estado leyendo el primer episodio de De donde son los cantantes" (99; Obras completas 1:306). Este elemento plástico del barroco relaciona a Borges con el barroco cubano de Arenas, Lezama y Sarduy. 
Ciertamente, en estos textos, los recursos compartidos son asombrosamente parecidos. Suzanne Jill Levine anota que otros textos del mismo libro Historia universal de la infamia muestran el "travestismo." Los textos citados son "El Incivil Maestro de Ceremonias Kotsuké no Suké” y "El tintorero Enmascarado Hakim de Merv" (99; Obras completas $1: 320 ; 324)$. Existe un desplazamiento en la escritura de Borges posterior, donde estos recursos están en función de otros elementos estéticos, sin embargo, aún en esos textos posteriores se puede detectar mucho de este primer barroco. El cuento "El Aleph" muestra una de las escenas de enumeraciones caóticas que después veremos aparecer en la poesía última de Borges (Obras completas 1:625, 627). Incluso en el libro

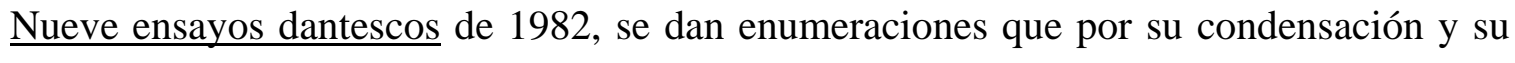
sentido aleatorio nos recuerdan mucho a ese primer Borges que venimos revisando, y a los textos más densos de Lezama. A este respecto véase por ejemplo "El encuentro en un sueño" (3:367-69).

Más adelante, veremos en detalle la relación de este recurso con los usados por Lezama en Paradiso y otros textos. En $\underline{\text { Paradiso }}$ se podrían citar el ritual fálico a que asiste José Cemí, protagonizado por el falo de Farraluque donde "Su glande incluso se parecía a su rostro" (343), y la escena de Cemí en el cine, donde la superposición de escenas se da de manera explícita, jugando con la metaficción del elemento cinematográfico (433). Tanto en Borges como en Lezama el barroco está en función de una erudición que, a veces, no existe otra manera de expresar.

Volviendo al barroco externo en Borges, existe obviamente un uso del travestismo y de los elementos plásticos en los textos de Borges analizados por Suzanne Jill Levine, recurso que se asocia a la parodia y que tiene mucho del montaje 
cinematográfico, como también demuestra el artículo (103). Un estudio que indague centralmente en estos usos respecto a la sexualidad estaría por hacerse en el caso de Borges. Lo cierto es que este tipo de barroco es cultivado por Borges y no es una excepción a lo largo de su carrera artística.

Revisemos ahora algunos textos del último Borges. El barroco externo en Borges está en el uso paródico de una hibridez cultural, en el uso de las enumeraciones caóticas y en otros tantos recursos propios del estilo como las condensaciones, según vengo revisando. Los textos incluidos en Nueve ensayos dantescos (1982) presentan una interesante combinación en este sentido. El tema dantesco, y el frustrado amor por Beatriz que siente el poeta, permite una síntesis entre la propia alegoría que implican los temas medievales, y el barroco suplido por la interpretación y la erudición borgeanas. Valga una cita para ilustrar cómo un discurso crítico es vehículo de la estética neobarroca: "Dos hechos me parecen indiscutibles. Dante quería que la procesión fuera bella [. . .]; la procesión es de una complicada fealdad. Un grifo atado a una carroza, animales con alas tachonadas de ojos abiertos, una mujer verde, otra carmesí, otra en cuya cara hay tres ojos [...] (Obras completas 3:368).

Borges vuelve al repetido artificio de la rescritura. A la vez que califica la escena de "complicada fealdad," se regodea en la polisemia de la textualidad dantesca. La elección de Borges parte de una intención crítica; pero la demostración posterior retorna a la metaficción. Borges nos asevera, refiriéndose a la Divina Comedia: "Dante, muerta Beatriz [. . .] jugó con la ficción de encontrarla, para mitigar su tristeza; yo tengo para mí que edificó la triple arquitectura de su poema para intercalar ese secuestro. Le ocurrió, entonces lo que suele ocurrir en los sueños, manchándolo de tristes estorbos" (369). Si la 
primera parte del texto en cuestión nos muestra al Borges crítico, que escudriña los sectores recónditos de la literatura desplegando una retórica de la demostración; la segunda parte vuelve a la metaficción, invalidando el valor documental de la primera. De esta manera, la enumeración caótica que ocurre en la procesión es una visión barroca del propio Borges.

En la poesía madura de Borges también se puede ver una reiteración de los recursos que vengo revisando. Dentro de los procedimientos barrocos usados por Severo Sarduy y por Borges, Suzanne Jill Levine asevera que "Los mecanismos de elipse que Sarduy y Borges comparten, para oponerse a la noción de 'esencia' en la literatura son, para empezar con Borges, primero 'las enumeraciones dispares' (o caóticas, como ha dicho Amado Alonso)" (101, el paréntesis es de Levine); y más adelante específica:

Un ejemplo de este procedimiento doble en Historia Universal es una descripción del asesinato de un hombre en 'El espantoso redentor Lazarus Morell' [. . .]. ${ }^{22}$ El significante primero será la 'vida', pero 'la vida' es una ausencia porque no se puede poner la vida en un texto sino palabras que se acercan al significado vida. (101-102)

En mi opinión hay una recurrencia a este uso y al estilo barroco en general en los últimos poemas de Borges. Las enumeraciones caóticas son frecuentes en los siguientes poemas aparecidos en La cifra: "Ronda", "Descartes", “Al adquirir una enciclopedia", “Aquel” y "Buenos Aires". En una especie de diálogo con la filosofía cartesiana, en “Descartes” Borges emprende una poesía un tanto desesperada y nostálgica:

He soñado la geometría.

He soñado el punto, la línea, el plano y el volumen. 
He soñado el amarillo, el azul y el rojo.

He soñado mi enfermiza niñez.

He soñado los mapas y los reinos y aquel duelo en el alba. (9-13)(Obras completas 3:293)

Estos poemas mencionados son un inventario, un ajuste de memorias en la mente del poeta, donde interesa más la enumeración vertiginosa de signos que la creación de imágenes propiamente dicha. Algo similar ha dicho Margo Glantz sobre el título El libro de sueños: “[ . .] es una antología textual de sueños donde se insertan algunos textos firmados por Borges" (27). Existe de esta manera un patrón común en los últimos textos de Borges. El barroco se ha desplazado de un estilo de repeticiones sintácticas y de juegos intertextuales, ambas técnicas ejemplos de yuxtaposiciones, a un estilo enumerativo que si bien existía antes, ahora hace catarsis.

Quizás intentando "la cadencia mágica," buscando ese estilo juanramoniano, Borges llegó a una síntesis de culturas, de superposición de textos e ideas donde "converge el autor universal y desaparece el escritor que el individualismo romántico nos ofrece como estereotipo" (Glantz 27). Según la propia crítica, Borges "es uno de los escritores que han logrado mayor capacidad de síntesis" (14). Pienso que la intensa lectura de textos y la profunda cosmovisión de la cultura occidental otorgaron a Borges esa idea de repetibilidad. Le otorgaron la visión de que no existe metáfora genuinamente novedosa. Borges es fiel a su introducción al inicio del libro al decir: "Al cabo de los años, he comprendido que me está vedado ensayar la cadencia mágica, la curiosa metáfora, la interjección, la obra sabiamente gobernada o de largo aliento" (Obras completas 3:290). 
Si nos abstraemos del Borges anterior a El Libro de sueños, pero aún más, del de

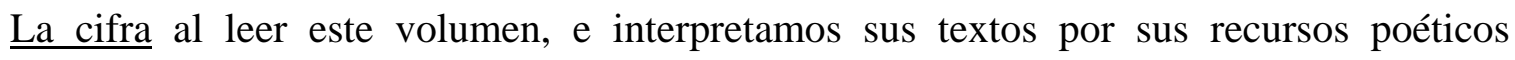
propiamente dichos, observamos la vuelta al barroco prefigurada por el mismo Borges en su prólogo a Historia universal de la infamia en 1954. En este prólogo Borges comenta sobre el barroco: "Yo diría que es barroca la etapa final de todo arte, cuando éste exhibe y dilapida sus medios" (1:291). Borges está más preocupado por yuxtaponer conceptos con los que ya ha atraído al lector, que con elaborar imágenes significativas. Hay indiscutiblemente una evolución en dicho barroco. Pero esta evolución es sólo un desplazamiento del foco de la elipsis que ahora más que metaliteraria es metaborgeana.

A pesar de la opinión de Cesar Augusto Salgado sobre "Borges's welldocumented evolution from the expressionist, baroque-oriented, aesthetic ideology of ultraismo in his youth to the classical, pantheistic view of literature of his mature years" (65), observamos una evolución que se circunscribe en una diferente forma del barroco, menos simbólica y elaborada; pero más autocentrada en su propia inmanencia metaliteraria. La "autofagia" se ha convertido en regurgitación, en rumia. Ahora Borges, como si se citara a sí mismo, utiliza de material fictivo su propio sistema mítico, profusamente elaborado durante años. Ése es el sentido en que he usado el término literatura diacrónica y sincrónica. En esta última etapa prima el sincronismo.

Algo similar a lo que sucede en el poema "Descartes" ocurre en "Al adquirir una enciclopedia":

aquí los neoplatónicos y los gnósticos, aquí el primer Adán y Adán de Bremen, aquí el tigre y el tártaro, 
aquí la escrupulosa tipografía y el azul de los mares. (4-7)(마as

completas $3: 296)$

Se ha soltado la mano que controlaba aquel texto de un barroco escolástico, de una lógica aparente donde se yuxtaponían los tiempos, las realidades, las apariciones al estilo del

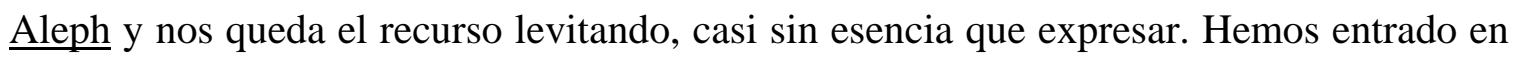
una etapa, más que neobarroca, neomanierista. El escepticismo de Borges y la saciedad de su intelecto dilapida medios en busca de un arte que no responde ya a ninguna realidad, ni siquiera a la realidad intelectual de los cuentos de Ficciones. Ha desaparecido el humor, la ironía y el juego metaliterario. Muchos de estos poemas son de excelente calidad, pero profundamente barrocos en el mismo sentido definido por el autor, y llenos de un escepticismo total. Simultáneamente se aprecia el panteísmo señalado por César Augusto Salgado (65) a través de los arquetipos.

Estos textos aparecidos en La cifra comparten con el manierismo el sentido de crisis y desasosiego. Esta crisis refleja de alguna manera la transición de la época moderna y la llegada del postmodernismo. Respecto al manierismo Luz Ángela Martínez ha dicho:

La crisis manierista se constituye con los siguientes elementos: Incidencia determinante de los avances y proyecciones científicas en la visión futura de mundo y de sujeto; crisis del humanismo determinada por la negación del concepto de naturaleza como canon de conducta rector y por la negación de la coincidencia entre el orden divino y el humano; negación de la coincidencia armoniosa entre cuerpo y alma; concepción de la divinidad como una entidad despótica; ausencia de fe en la posibilidad de 
la salvación y la trascendencia; imposibilidad de pronunciarse con criterios ciertos sobre la realidad. (Screens 4-5)

Estos elementos están definitivamente presentes en los temas borgeanos. Primeramente, la "incidencia" de la ciencia, en la "visión futura del mundo" se puede comprobar en innumerables textos, entre ellos "La doctrina de los ciclos," al cual he dedicado un tiempo aparte. Toda la especulación sobre el tiempo, la historia, y los arquetipos en los textos de Borges está, en definitiva, nutriendo una ideografía de la aceptación de las teorías científicas de la época. Borges refleja las preocupaciones universales que habían planteado las teorías de Carl Gustav Jung, Einstein y otros. Pero su componente desconstructivo y poético lo hace negar cualquier solución definitiva a estos problemas. Ahora, es la "imposibilidad de pronunciarse con criterios ciertos sobre la realidad" el elemento que ha identificado la escritura de Borges, y el que define su escepticismo.

En los últimos textos de Borges, entre ellos La cifra, la historia cultural de la humanidad nos pasa por delante como en el posthumanismo al cual se refiere Luz Ángela Martínez: “Todos estos elementos de finales del siglo XVI reaparecen y se acentúan en el Neobarroco, también en la crisis de mundo expresada por éste, y que estamos conociendo como posthumanismo" (Screens 4-5). El manierismo nos debe servir para extender los recursos borgeanos, a cierta zona donde Lezama conjugó su imago como solución o alternativa salvadora. En Lezama se trata de conciliar el orden divino y el humano a través de ese sistema de imágenes. Pero ambos, Borges desde su confianza en la literatura como vehículo humanizador, y Lezama desde su imagen redentora, proponen cierta solución a la crisis. 
Todos estos momentos demostrativos en que he revisado recursos barrocos deben verse, en conjunto, como un arsenal expresivo del cual se vale el autor. Reitero que el barroco en Borges es un recurso ligado a las posibilidades del lenguaje, que siempre lo acompañó. En la primera posdata a "Las Kenningar" Borges dijo: "El ultraísta muerto cuyo fantasma sigue siempre habitándome, goza con estos juegos" (Obras completas 1:380). Ese goce estético que derrocha los recursos frente al lector en ostentación de una rigurosa lógica que logra desarmarse y demostrar lo ilusorio del propio recurso, pero a su vez su versatilidad novedosa, es el fantasma barroco que acompaña a Borges. Ese mismo fantasma le dedica ardientes textos a Quevedo (2:38-47) y siempre pagó tributo a Cervantes, incluso en el uso de técnicas de escritura.

En mi recorrido por tipificar la poética de Borges y Lezama, como algo polar y complementario a la vez, he dividido esta sección en las tres partes mencionadas al inicio del capítulo. Al entrar en la demostración del barroco externo en Lezama, debo recordar que la intuición inicial que me sugirió este estudio se basó en el antimaterialismo visible en ambos autores. Para Lezama el gozo en la complejidad de la realidad, y ese interés por plasmar tal contraste en texto, es una espiral barroca, autoconsistente, que gira al rededor de sus propios cánones. El autor desarrolla esta perspectiva, como axiología estética, mucho más allá de cualquier causalidad de la que parte. Esto es una extención de lo que Lezama denomina "lo hipertélico," y a lo que Sarduy se refiere en "Escrito sobre Dador": "Algo así como lo que sucede con insectos que durante el apareamiento matan a la hembra y van más allá de lo deseado, por lo cual son, para decirlo en lenguaje técnico, hipertélicos. ${ }^{23}$ No hay mejor definición de la poesía de Lezama: siempre va más allá del fin propuesto [... ]" (Antología 144). 
Lezama también comparte con Borges ese barroco de primer orden que vimos en la sección dedicada al escritor argentino (Levine 102-103). Esto se da en Lezama con mucha más audacia en cuanto a temas de connotación sexual y con una exposición del barroco más deliberada y consistente. El sensualismo en Lezama abarca distintas formas de expresión y crea escenas audaces que Borges, sin embargo, refleja menos incisivamente. Lezama combina la condensación que hemos visto en Borges, con otros recursos metafóricos, aludiendo a campos semánticos connotativos.

El barroco externo es un mecanismo de la elipse donde el texto aparece como centro de sí mismo, es autoreferencial. El mismo sentido "hipertélico" de los textos de Lezama, se halla en el hedonismo literario borgeano. En su forma externa, el barroco de Borges no tiene sustanciales diferencias con el barroco lezamiano o el barroco de Carpentier, por sólo poner un ejemplo. Recordemos las escenas citadas de El reino de este mundo. En esta novela Carpentier usa el mencionado método cinematográfico en la escena de las cabezas que contempla Ti Noel (9-11). Lezama hace gala de este recurso en múltiples escenas de sus novelas Paradiso y Opiano Licario. Observemos la introducción de la escena para ver toda la carga lúdica y paródica de ésta: "Cuidaba el patio un alumno de la clase preparatoria, [. . .] un tal Farraluque, cruzado de vasco semititánico y de habanera lánguida, que generalmente engendra un leptosomático adolescentario, con una cara tristona y ojerosa, pero dotado de una enorme verga" (Paradiso 342).

La narración linda con un discurso seudocientífico que pretende esconder el real carácter lúdico de la situación. En este sentido, el ejemplo es ligeramente parecido a la refutación seudocientífica que Borges asume en "La doctrina de los ciclos," en cuanto a la pretensión de conocimiento que el narrador implica. Borges utiliza lo que he 
denominado lógica retórica, como demuestro en la sección de la yuxtaposición barroca. En este caso Lezama persigue fines absolutamente diferentes, pero aún así, la frase que se refiere a los resultados del cruce entre el vasco y la habanera y la clasificación sicológica "leptosomático adolescentario" pretenden una generalidad científica, que persigue la verosimilitud y (ab)usa igualmente de esa retórica seudocientífica de la que hablaré en el caso de Borges.

Luego de esta introducción Lezama entra en la apoteosis carnavalesca propiamente dicha. Reproduzco aquí la cita completa para luego pasar a su revisión textual:

Era el encargado de vigilar el desfile de los menores por el servicio, en cuyo tiempo de duración un demonio priápico se posesionaba de él furiosamente, pues mientras duraba tal ceremonia desfilante, bailaba, alzaba los brazos como para pulsar aéreas castañuelas, manteniendo siempre toda la verga fuera de la bragueta. Se la enroscaba por los dedos, por el antebrazo, hacía como si le pegase, la regañaba, o la mimaba como a un niño tragón. La parte comprendida entre el balano y el glande era en extremo dimenticable, [. . .] Esa improvisada falaroscopía o ceremonia fálica era contemplada desde las persianas del piso alto, por la doméstica ociosa [. . .]. (Paradiso 342-43)

Focalizando la evolución intelectiva del narrador vemos el paso de un hecho que inicialmente se plantea como verosímil. El hecho de que un estudiante mayor sea el encargado de vigilar a los menores es un acto razonable e incluso común. Luego el narrador introduce el vocablo "desfile" que es la primera clave del acto teatral que sigue. 
Semánticamente hablando, la progresión se da a través de los vocablos "demonio", "furiosamente" y "ceremonia desfilante" donde ya, con esta última, se declara la intención apoteósica del acto. Comienza entonces la enumeración propiamente dicha. Los términos ahora se yuxtaponen para buscar el efecto gráfico, de ritual, que nos recuerda esa teoría de Sarduy, ya citada, sobre el "despilfarro" o la "fastuosidad cromática" (Simulación 16). Cabe mencionar que dicha teoría es, en definitiva, una irradiación valida de la idea lezamiana expresada en el concepto "hipertélico." Este montaje, o superposición de imágenes, es una marca del neobarroco como método puramente fictivo. Se detiene abruptamente la acción dramática de la narración y retardando el tempo, comienza una descripción que abruma, que sobrecoge y carnavaliza.

Lo grotesco de la escena nos remite a fragmentos de Gargantúa y Pantagruel o a descripciones quevedeanas; pero el regodeo en lo erótico es índice propio de ese neobarroco postmoderno que germina en las obras de Reinaldo Arenas y del propio Severo Sarduy. La apoteosis llega con la prosopopeya fálica: "Se la enroscaba por los dedos, por el antebrazo, hacía como si le pegase, la regañaba, o la mimaba como a un niño tragón" (Paradiso 343). Después de esta apoteosis Lezama vuelve al discurso seudocientífico con la nomenclatura médica de las partes del pene, "balano", "glande" y luego retira al narrador al "piso alto" desde donde la doméstica ociosa, observa la “improvisada falaroscopía." La doméstica es el punto donde se reúne la escena. Ella es quien da la perspectiva total e hilarante. De manera que la falaroscopía es también telefaloscopía. Con este cambio (embrague) de perspectiva final, Lezama pone al lector a observar la escena. 
Sutilmente están aludidos aquí la ficción de racionalidad, dada por la retórica demostrativa, la perspectiva microespacial lograda con la focalización de las partes del pene, y el juego lezamiano con el receptor. Por coherencia expositiva sólo me interesa enfatizar ahora el montaje gráfico que contiene la escena. Aunque sostengo que el barroco en Lezama se da generalmente dentro de la imagen y es, por ende, de carácter metafórico y cosmopolita en un sentido icónico. En éste y en otros casos existe esta forma de yuxtaposición cinematográfica que también se da en Borges. La escena es una justificación para presentar el carnaval, he ahí la retórica del neobarroco y la ficción de racionalidad. Posteriormente Farraluque se cubre "con una máscara ceremoniosa" (343). Lezama está jugando con los recursos de la mimesis y el carnaval; pero también se cuestiona la identidad. Farraluque, mediante su ritual se transforma, pasa a ser su propia caricatura.

En Oppiano Licario, novela que sigue a Paradiso, tenemos también ejemplos de acumulación barroca con la misma carga homoerótica que la anterior. El narrador, describiendo una escena carnavalesca dice:

[ . . ] adolescentes, [ . . ] abandonaban sus ropas sin importarles la certeza de su recuperación y lucían su abullonada geometría. [ . . .] Un dios irritado, cautelosamente traslaticio y engañador, cuya cólera, al alcanzar su plenitud se hacia dueña de toda la llanura, era recibida con chumba, con risotadas, con hollejos volantes, con paga doble en las cantinas. Con risitas y orinadas en todas las esquinas (sic), [. . .] Niñas que habían sacado del colegio se apeaban de las máquina para contemplar en las pocetas la desnudez de los saltimbanquis acuáticos. En los balcones las ancianas 
venerables precisaban en sus manos temblorosas los anteojos que les acercaban los frutos de la juventud. Los nadadores se pegaban nalgadas que despedían chispas, flotaban silenciosos como si su protuberancia fuera una vela latina. (322)

De nuevo se nos presenta el carnaval erótico como si el inconsciente colectivo de la isla hiciera catarsis en ese circo-festín en el cual el Malecón habanero, es la platea. En lugar de un Farraluque aquí tenemos muchos adolescentes, cuya asociación no se hace esperar cuando líneas más adelante Lezama habla de una "sensualidad helénica" (322). Una gran diferencia entre Borges y Lezama es precisamente este uso de la sexualidad, y de la sensualidad en otras ocasiones. La osadía de Lezama radica en haber expresado estas ideas dentro de la mojigatería de un régimen intolerante al homosexualismo. ${ }^{24}$

Estas escenas estudiadas nos presentan un aspecto del barroco Lezamiano. Es ese punto donde muchos escritores se han encontrado si descontamos la osadía temática. El uso de esa técnica de montaje, del estilo cinematográfico se puede encontrar en Julio Cortázar, Gabriel García Márquez, Alejo Carpentier, Severo Sarduy, Cabrera Infante. De hecho, lo hemos visto en Borges y en Lezama. En la novela Paradiso existen otros varios ejemplos de este recurso. La escena de Farraluque no es un ejemplo aislado. Uno de ellos, en esta ocasión mucho más cercano al estilo de Carpentier, aparece en la novela cuando el narrador nos pasea por las vidrieras de la calle Obispo:

De la vitrina su mirada logró aislar dos estatuillas de bronce, [. . .] Pero era innegable que las figuras agrupadas en la vitrina no querían o no podían organizarse en ciudad, retablo o potestades jerarquizadas. Estaban como en secreto impulsadas por un viento de emigración, esperaban tal 
vez una voz que le dijese al buey, a la bailarina y al guerrero, o a la madera, el jade o el cuarzo, la señal de partida. El espíritu del cuerno de caza, colocado sobre aquel tumulto, parecía señalar el nacimiento de la nueva ciudad [...]. (531)

Este ejemplo de enumeración caótica es mucho menos osado que el anterior y está justificado por el referente emblemático. Tiene sin duda una carga importante de realismo mágico, donde se dan esas realidades insólitas para lograr lo fantástico. El uso de los recursos y las técnicas barrocas en Lezama es polifacético. Este último ejemplo apoya la idea de que la escena de Farraluque no es una singularidad en Paradiso.

En la novela se da un caso mucho más explícito de barroco de montaje y superposiciones. Esta es la escena en que Cemí va al cine a ver una versión de Isolda y se entretiene, además de en las escenas de la película, en contemplar las evoluciones eróticas de Lucía y Fronesis (433). Este caso de superposición es un claro ejemplo de metaficción. Veamos cómo procede la escena. Cemí entra al cine y: “antes de proyectarse en el pantallón que lo miraba, su vista lograba la acomodación saltando por encima de los espectadores" (432). Posteriormente a la ubicación de Cemí en el cine, comienza la superposición de imágenes: "Cada vez que el proyector situaba un claro, Cemí miraba con cautela las lentas variantes en las posiciones de la pareja. Se veía que la hembra se subdividía y anegaba cada vez más por las hormigas del Eros. Sus labios iban trazando el ornamento de un círculo húmedo en la garganta de Fronesis" (433). El narrador crea una ilusión de sombras chinescas que establecen una trama paralela a la del filme.

La escena continúa llevando acciones paralelas en un crescendo de tensión dramática: "Con la espalda sobre la arena, las dos manos en la nuca, Isolda flexiona sus 
piernas. Muestra por un instante sus interpiernas [ . . .]" (433). A esta escena cuyo tiempo está marcado por la narración del filme, sigue la escena de Lucía y Fronesis marcada por el tiempo novelado: "El proyector fija un claro anchuroso, donde la mirada de Cemí se lanza sobre la pareja. [. . .] Ve a Fronesis cruzarse el índice sobre los labios, indicando silencio. Ve que Lucía empieza a sollozar" (434). Lezama ha armado un clásico montaje cinematográfico desvelando el origen metafictivo de la novela. Lezama, al igual que Borges, usa de estos recursos donde la ficción se refiere al proceso creativo y es construida con la materia prima fictiva existente en la cultura. Ténganse en cuenta los casos de Muerte de Narciso y "Rapsodia para el mulo," como ejemplo de este recurso en el que se reflexiona sobre el proceso de la escritura. Lezama nos declara ese propósito, en la escena estudiada, cuando dice refiriéndose a Cemí: "Su película, su caza, su incitatus, era la pareja" (434).

Los recursos barrocos que Suzanne Jill Levine estudiaba en la obra de Borges, "El atroz redentor Lazarus Morell," son típicos y abundantes en toda la narrativa lezamiana. Las dos novelas del autor cubano son sumamente prolijas en estos ejemplos. Me refiero al montaje, a la yuxtaposición de imágenes que en ocasiones llega a la apoteosis. Opino que en Paradiso y Oppiano Licario se encuentra el neobarroco lezamiano más acendrado. Lejos de haberse llegado a formas de expresión más claras o sencillas se condensan todos los barrocos. Paradiso y Oppiano Licario son el exordio de todas las técnicas barrocas. Estas novelas son la etapa final donde se exponen y dilapidan los medios del artista, para repetir de nuevo las palabras de Borges (Obras completas 1:291). Pero la constancia del estilo barroco en ambos, nos demuestra que etapa final significa también maestría en el arte de escribir. 
He mencionado dos tipos de recursos barrocos. Uno que considero externo y formal y otro interno y de contenido que permite ver mejor las verdaderas pautas del estilo lezamiano. Hay que aclarar que la isotopía textual en Lezama es de tal complejidad y densidad, no sólo metafórica, sino conceptual, que resulta trabajoso discriminar entre un discurso y otro en un mismo macroenunciado. Los recursos barrocos que hemos visto hasta ahora en Lezama, tienen que ver con un barroco externo e intertextual. Los ejemplos de escenas carnavalescas donde se solapan las descripciones dando ese sentido de montaje o yuxtaposición que hemos observado, en las escenas de Farraluque o de los jóvenes en el Malecón, nos permiten ciertamente ver el gusto de Lezama por el barroco clásico y pintoresco, por el montaje cinematográfico. Esto es en cuanto a forma. Es cierto que en cuanto a contenido hay novedad en los temas que trata Lezama con respecto a sus coetáneos.

Este barroco visto tiene también cierto apego a la escritura epocal, donde barroco y realismo mágico se dan la mano. Sea quizás este recurso el precio que paga Lezama por ser escritor de su tiempo, ya que no se puede ser nunca entera y absolutamente novedoso. El tema homoerótico tratado por Lezama, y el uso de recursos barrocos para recrear estos temas, deja su impronta en las posteriores obras de Arenas y Sarduy, como he sugerido. Pero los recursos de montaje y enumeración caótica, en general, lo comparten Borges y Lezama. Las peculiaridades hay que buscarlas en la metaforización frente a la yuxtaposición barroca.

En términos de definir una poética como intenta este trabajo, es imprescindible enfocarse en los recursos barrocos usados en la narración a nivel retórico. El barroco en Borges no siempre puede ser detectado bajo la misma especie. En otras palabras, para mi 
propósito, los recursos de índole plástica que he revisado, aunque son genuinamente barrocos, no son recursos regulares en los textos de mayor éxito. Sí lo son la demostración retórica, y la yuxtaposición barroca, no ya a nivel de montaje cinematográfico esta última, sino de una forma mucho más sutil, como el caso de la demostración científica que Borges lleva a cabo en "La doctrina de los ciclos" (Obras completas 1:385).

\section{b. La perspectiva macroespacial y la yuxtaposición barroca.}

El barroco por yuxtaposición borgeano se da dentro de la isotopía textual y persigue un fin de verosimilitud. A simple vista Borges nos parece diáfano y puramente analítico. La forma en que introduce sus narraciones parte de una linealidad que nos va adentrando en el argumento. Luego de esa primera parte propositiva, Borges desata la incongruencia del asunto. Sus textos incluyen el barroco, el adorno yuxtapuesto al texto. La narración en Borges parece ser inteligentemente lógica, pero por resquicios de esa demostración, por incongruencias propia de la interpretación, se insufla la ambigüedad.

La escritura de Borges es un ejemplo práctico del fallo del racionalismo positivista, llevado a cabo con los recursos propios de éste. Por eso, pienso que Borges replica la técnica de atraer al lector con recursos conocidos y aceptados por la época, para desde dentro, plantear su nueva visión. Ésta es la enseñanza y la afinidad de Borges con Miguel de Cervantes. La diferencia es que Borges está trabajando con material filosófico e ideológico, con los mecanismos que nos permiten entender la realidad. Nos vemos reflejados en la obra de Borges, como una civilizacion capaz de explicarse a sí misma, y explicar su función en el universo con una bella construcción lógica. Pero a su vez, 
percibimos el miedo de haber hecho una falsa construcción. Estos recursos se ven en la demostracción retórica borgeana que se da en la lógica discursiva.

Por eso hablo de un barroco por yuxtaposición. No al nivel de la metáfora barroca, sino a nivel de usos retóricos, de ese otro discurso alegórico que se arma, en parte, por la estructura especular de la que nos habla Jaime Alazraki en su estudio (Versiones 148), y en parte por la futilidad de perseguir una racionalidad inexistente. El barroco en Borges tanto como en Lezama tiene mucho de intencionalidad y de recurso fictivo. El componente ontológico que llevaba el primer barroco, así como el miedo a Dios y al saber, asoma en los textos de los autores que nos ocupan como silogismo estético, y cargado de un paganismo que demuestra su carácter de recurso fictivo y su pertenencia postmoderna.

En consonancia con ese afán de suplantar la realidad por una realidad literaria, el barroco parece acudir a Borges en la medida en que permite crear una escritura autoconsistente que funge como parodia del texto. Este mecanismo a su vez le permite usar estructuras y estilos conocidos y aceptados por la convención del lector para garantizar su asimilación (Sarduy, Notas 555). El título del libro Ficciones ya juega con esta idea de por sí. Declarar el concepto ficción como título de un libro que a un tiempo se anuncia como creación y como parodia, es quizás el primer elemento de demostración que arroja Borges. Los temas del volumen en cuestión son recuperados del archivo literario de la humanidad. Borges crea ficciones que ya están creadas, parece decirnos. En ese proceso continente, el lector se ve representado al ser parte de la cultura que se mitifica. En ello radica el efecto inquietante que sus textos producen. Escuchemos la explicación en palabras del propio autor: 
“¿Por qué nos inquieta que el mapa esté incluido en el mapa y las mil y una noches en el libro de Las Mil y Una Noches? ¿Por qué nos inquieta que Don Quijote sea lector del Quijote y Hamlet espectador de Hamlet? Creo haber dado con la causa: tales inversiones sugieren que si los caracteres de una ficción pueden ser lectores o espectadores, nosotros, sus lectores o espectadores, podemos ser ficticios. (Obras completas 2:47)

La parodia y el oximoron son frecuentes en otros títulos de la obra de Borges. Esto podría entender como un abuso retórico, a no ser por el carácter escéptico y humorísticamente irónico de muchos de los textos, cuyas peculiaridades también me interesa investigar en este estudio. Según Suzanne Jill Levine, en Historia universal de la infamia, "Borges se burla de Historia y Universal, al escribir las historias de siete infames en el espacio de 92 páginas” (97). Esa leve risa intelectual de escritorio, común también en Lezama como veremos en su momento, se regodea en presentarnos el sintagma hiperbólico "Historia universal," a la vez que intenta parodiar los métodos de la investigación histórica.

Hipérbole y parodia son aquí dos términos barrocos. Pero la poética de Borges va más allá. El genitivo "de la infamia" hace de esta historia una historia marginal, postmoderna. Además, el carácter deconstruccionista de esta historia de la infamia es también postmoderno ya que es una historia, no "historiada" hasta ahora, por lo que se cuestiona a la Historia con mayúscula, a la verdad de nuestra memoria cultural. Por otra parte, la incorporación del discurso histórico, del discurso científico, de la estructura cinematográfica y del pastiche, le dan a esta escritura un carácter neobarroco. Borges usa elementos parecidos a los de Cervantes, al criticar la obra desde la obra, pero lleva el 
recurso a una extensión de fuentes absolutamente nueva y deliberada. Por esas características, este elemento neobarroco influyó tanto en el neobarroco de Sarduy. Cito a Suzanne Jill Levine: “Así que, como en el caso de Borges, en Sarduy la parodia sirve de crítica literaria y al mismo tiempo enriquece, renueva la creación literaria" ( $\underline{\text { Severo }} 96)$.

Margo Glantz demuestra cómo los textos de Borges usan atemporalmente la intertextualidad, cómo están conformados sobre esos escombros de la literatura hasta tal punto que se convierten en "un nuevo concepto explícito de la escritura" (22), en una especie de identidad de todas las identidades. El artículo en cuestión toma como ejemplo "Historia universal de la infamia, fechado en 1935, y Libro de sueños, aparecido en 1976” (21). A través de este recorrido, se demuestra la constancia del recurso intertextual en Borges, que en mi opinión es una forma de parodia. Margo Glantz, refiriéndose a

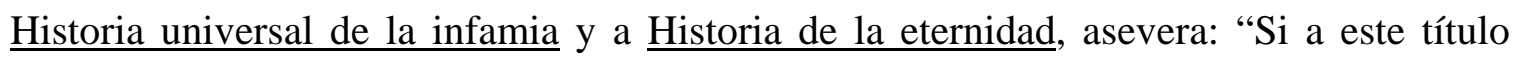
agregamos el de Historia de la eternidad [. . .] esta constatación se vuelve en sí misma una hipérbole. La intención de intertextualidad es delirante [. . .]” (22). Posteriormente, el estudio citado compendia las fuentes de intertextualidades en Borges: "Un libro de Mark Twain, la Enciclopedia Británica, una historia de la piratería, otra sobre los gangsters de New York, textos de Swedenborg, Las mil y una noches, El Libro del Conde Lucanor, etc" (23).

Lo que hemos visto hasta ahora es una forma sui generis del neobarroco borgeano. En Ficciones, así como en Historia universal se da un "reciclaje", una reabsorción de la literatura, a la vez que una parodización irreverente de la historia. La opinión de Santiago Juan-Navarro sobre "Tema del traidor y el héroe" es aplicable, en todo caso, a muchos de los textos del autor: "La historia no es el simple reflejo de una 
realidad verificable, sino una estructura verbal que se acomoda a la poética del discurso narrativo" ("Las formas" 31). Posteriormente el crítico agrega: "el propio texto crea un universo paralelo al de la historia que acaba por devorarse a sí mismo" (31). Estos textos tienen de barroco el uso de la parodia, la hipérbole, el oximoron, apoyado por la propia retórica discursiva interna del texto. El nivel semiótico al que se realiza el juego paródico y la forma de implicar al lector en éste son novedosos. Por eso he dicho que la escritura de Borges, más que barroca, es neobarroca.

El título Historia de la eternidad, cuyo prólogo es de 1953, presupone un oximoron al pretender ser historia del pasado y del futuro. Anotar la historia de la eternidad es conocer de antemano tal eternidad o, intuir que al descifrar los códigos o arquetipos que encierran los mecanismos de esa eternidad, ésta puede ser generada (prefigurada) como por un algoritmo. Una idea similar se encuentra en la matriz generativa del álgebra matricial. Hay dos ideas en cuestión, la de conocer la historia de la eternidad porque es repetible y la de generarla por medio del pensamiento lógico mediante un hallazgo de sus códigos.

Sería algo similar a desarrollar una teoría que nos permita describir exactamente un árbol específico, siguiendo el estudio de las regularidades de los árboles existentes, frente a la posibilidad de predecir exactamente un árbol específico, a partir de las características de su semilla. Las posiciones sobre la historia serían: ésta es repetible y por tanto predecible, o la historia está contenida en una forma potencial susceptible de ser descifrada. Dos ideas coexisten en los textos de Borges y ahí también se da su neobarroco. Un neobarroco no tanto estilístico, como demostrativo. La estructura mental 
de Borges procede como la de un científico: ha borrado los límites entre la ciencia y la literatura.

Borges usa de un barroco que tiene por trasfondo el escepticismo, por lo que levita girando en torno a la literatura. Este barroco se da por capas, no es estructural (del signo lingüístico), sino yuxtapuesto, empastado. La escritura de Borges representa una elipsis autónoma que no precisa de otro referente que la propia literatura. Una literatura, valga la aclaración, diacrónica y sincrónica. Diacrónica entendida como literatura acumulada en el registro cultural de la humanidad y sincrónica como proceso puntual de literatura que se crea simultáneamente a nuestra lectura, donde el discurso nos lleva a sus propias conclusiones. En el primer caso, el barroco es de orden paródico; en el segundo, de orden retórico. Borges usa ambos. Veremos cómo, en contraposición a Lezama cuyo barroco es sensorial, Borges exhibe un barroco perceptual más desplazado a la expresión que a la impresión. Lezama siente de forma barroca; Borges percibe/expresa de forma barroca.

Historia de la eternidad, en su función deíctica, es historia de la literatura. Es una historia que según Borges sí se puede anotar, ya que reside en la iteratividad, en la finitud de las metáforas posibles y en la lógica del discurso. Este segundo caso de barroco o barroco retórico, está implicado en "La doctrina de los ciclos" donde Borges, a través de la lógica retórica, demuestra el fin del universo: "La luz se va perdiendo en calor; el universo, minuto por minuto, se hace invisible. Se hace más liviano, también. Alguna vez, ya no será más que calor: calor equilibrado, inmóvil, igual. Entonces habrá muerto" (Obras completas 1:391). Si el escepticismo de Borges consiste en dudar del registro de nuestras percepciones o de nuestra capacidad de entender el orden universal 
(epistemológico), entonces su argumentación es una pura ficción. Si por el contrario, Borges confía en los postulados de la ciencia que le es cotemporal y su línea de razonamientos lo lleva a la destrucción del universo, entonces su escepticismo es ontológico.

El escepticismo de Borges ha sido documentado. Hemos discutido el tema al presentar la afirmación de Donald Shaw que dice: "Si no existe un Dios que garantice la veracidad de las impresiones que recibimos a través de los sentidos [. . .] se sigue que está desprovista de todo fundamento cualquier confianza en nuestro poder de reconocer y de explicarnos lo verdaderamente real" (34). En el texto en cuestión, "La doctrina de los ciclos," Borges no duda, asevera el curso del universo, explicando las consecuencias termodinámicas del estado de máxima entropía a que fluye todo sistema. Puede pensarse que el escepticismo de Borges no radica en la imposibilidad de conocer la realidad, sino en la constatación del caos intrínseco a todo orden. Recordamos una vez más las palabras de Donald Shaw al respecto: "La duda de Borges de si el mundo es un caos total, o bien un orden secreto que no sabemos descifrar, está resuelto positivamente por Lezama Lima" (156). Con esta aseveración hemos llegado a una contradicción entre el texto de Borges y los planteamientos del crítico, a no ser que el deux ex machina del barroco borgeano nos salve de tal disyuntiva.

"La doctrina de los ciclos", texto que forma parte de Historia de la eternidad, ofrece ciertas claves para la solución del asunto, además de ser relevante en cuanto al tipo de demostración que Borges usa en otros relatos. Borges trata el tema científico con adjetivaciones y nomenclatura literaria. El goce se centra en la posibilidad fantástica de la palabra, en el disfrute de acompañar a la mente por esos laberintos del razonamiento. 
El sintagma doctrina de los ciclos ya presupone un barroco al abordar los ciclos de manera hiperbólica. Un tratado científico comenzaría por "Los ciclos..." y no por la doctrina de ellos. Por otra parte, la palabra doctrina, que entró en algunas lenguas modernas alrededor del siglo XIV (Merriam 342) y que es fácilmente asociable a dogma o creencia, trae gran parte de su carga significativa de la escolástica, lo que hace pensar en la retórica barroca eclesiástica; de hecho, Borges cita a San Agustín dentro del texto en cuestión (Obras completas 1:388).

Otra clave importante en el texto es su propio inicio. Borges trata de refutar la doctrina de los ciclos y comienza: "Esa doctrina (que su más reciente inventor llama del Eterno Retorno) es formulable asî’" (385). Es interesante que Borges menciona que la doctrina tiene un "más reciente inventor". De nuevo, reciente e inventor es el documentado oximoron borgeano y sin duda un uso barroco en su escritura, pero además, dice de la doctrina que es "formulable". Este epíteto nos muestra que la doctrina puede ser formulada de distintas maneras, lo cual está en contra de la correspondencia unívoca del discurso científico.

De igual manera el oximoron formado por los vocablos "es" y "formulable", en lugar de "puede ser formulable" o "podría ser formulable", nos da la clave del elemento de verosimilitud que Borges le otorga al texto. Esta mirada cercana, al sintagma en cuestión, nos muestra dónde reside el proceso de anti-demostración que se solapa en la misma demostración. Tal proceso ocurre en otro nivel del lenguaje. A esto nos referíamos en páginas anteriores, al decir que por los resquicios de la demostración, por incongruencias propias de la interpretación, se insufla la ambigüedad. El lector intuye esa intención, pero sólo una lectura atenta y minuciosa, que se concentre en los niveles 
medios de la estructuración del lenguaje (morfológico, léxico, sintáctico), puede develar los recursos en que se basa.

Otra prueba a favor del barroco retórico que se esconde en la demostración científica para garantizar la recepción, a la vez que critica la ciencia desde la ciencia, como el Quijote de Cervantes hace con la literatura, es la acolación final donde Borges dice: "Entre los libros consultados para esta noticia anterior, debo mencionar los siguientes" (392). Primeramente, el carácter connotativo del vocablo noticia tiene una fuerza que implica al lector. Una noticia es algo que debemos escuchar porque nos implica con sus consecuencias. Ése es uno de los recursos que Borges recupera de su teoría de la inquietud en "Magias parciales del Quijote," que ya hemos citado oportunamente (Obras completas 2:47).

En segundo lugar, es un eufemismo llamarle noticia a un ensayo cuyo rigor científico debe haberle tomado a Borges mucha lectura y elaboración. Borges ha recorrido en catorce páginas dos siglos de cultura. En orden cronológico aproximado el ensayo incluye a los primogénitos de la casa de Egipto, la cosmogonía de los estoicos y la opinión de éstos sobre Zeus (1:387); incluye los evangelios, a Virgilio, a San Agustín (388), a Rutherford, a Nietzche, y a Unamuno, entre muchos otros textos, escritores, pensadores y culturas.

La inclusión no va sólo en sentido temporal. Historia de la eternidad examina concentradamente ciertas ramas del saber. Este elemento está en plena contradicción con el término "noticia" con que Borges lo cataloga en su conclusión. Forman parte de esta seudodemostración las matemáticas (385-86), la filosofía, la literatura y la religión. Quizás un análisis más profundo de la relación numérica nos demuestre una relación con 
la cábala. Pero lo más importante respecto a la dicotomía noticia/ensayo, es el rigor con que Borges desarrolla la refutación del mito del "Eterno Retorno" (385). Conviene revisar en detalle, al menos uno de esos trozos de demostración. Cito sólo una explicación científica de las varias que contiene el texto:

El diámetro de un átomo de hidrógeno ha sido calculado, salvo error, en un cienmillonésimo de centímetro [. . .] Rutherford lo define según la imagen de un sistema solar, hecho por un núcleo central y por un electrón giratorio, cien mil veces menor que el átomo... concibamos un frugal universo compuesto por diez átomos [ . . ]. (385)

Para un texto de 1934, catorce años después que Einstein descubriera el efecto fotoeléctrico basado precisamente en el modelo atómico de Rutherford, el narrador está sumamente informado, actualizado. Borges ha hecho una descripción envidiable para un científico, donde ni siquiera deja afuera la propagación de error ("salvo error") de una medición finita.

El recorrido cronológico-cultural que ha hecho el narrador, la diversidad de las ramas del saber que ha utilizado, sumado al rigor y actualización con que se lleva la refutación, están del lado de la demostración científica. El uso de la nomenclatura literaria (doctrina), el título hiperbólico "doctrina de los ciclos" en lugar de "Los ciclos del universo," u otro semejante; el oximoron "es formulable," como otros tantos que pueden encontrarse dentro del texto, y finalmente, la clave deconstrutiva "noticia" al cierre del relato, están del lado del barroco retórico. Se pueden, así mismo, mencionar otras adjetivaciones pertenecientes a la ficción, que aunque no destruyen la ilusión de 
discurso científico, sí demuestran cómo el texto pretende ser puramente literario y se niega a sí mismo en su conclusión.

Borges vuelve a la elipsis metaliteraria donde el referente no importa si nos proporciona un goce estético superior. La demostración científica sirve al narrador de agarradera lógica, pero detrás de ella se esconde la refutación de la refutación. El texto opera una especie de "autofagia" (Juan-Navarro, "Las formas" 31). Su neobarroco ha encontrado una síntesis entre todos los discursos. Borges opta por el escepticismo epistemológico, refutando con rigurosidad teórica el mito del eterno retorno y refutando también su refutación. Otros títulos que apoyan esta idea, además de Ficciones, $\underline{\text { Historia }}$

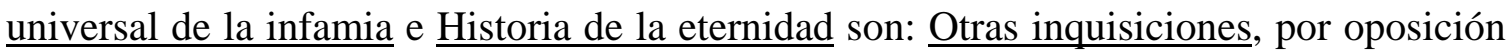

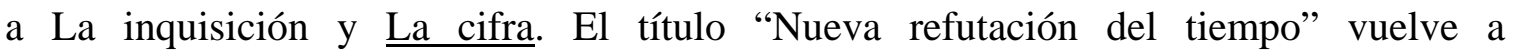
demostrarnos el oximoron dado por el par nueva/tiempo. Es decir, en un recorrido que va

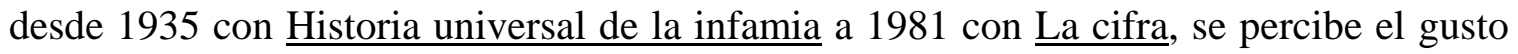
por ciertos recursos barrocos en Borges.

Veamos otro pedazo de análisis textual, esta vez del relato "Historia de la eternidad." Obsérvese el estilo perifrástico y elíptico de la escritura:

La tarde que precedió a esa noche, estuve en barracas: localidad no visitada por mi costumbre, y cuya distancia de las que después recorrí, ya dio un extraño sabor a ese día [. . .]. No quise determinarle rumbo a esa caminata; procuré una máxima latitud de probabilidades para no cansar la expectativa con la obligatoria antevisión de una sola de ellas. (Obras completas $1: 365)$ 
Si se presta atención a las oraciones y/o sintagmas "la tarde que precedió a esa noche," "localidad no visitada por mi costumbre," "para no cansar la expectativa," se ve claramente que el narrador usa un lenguaje indirecto y alusivo. En el primer caso, se sitúa a la tarde a partir del referente temporal posterior. Es la tarde que precedió a una noche. Podría haber sido la tarde de tal fecha, pero al narrador le interesa introducir el elemento de misterio haciéndonos mirar esa noche.

La oración "localidad no visitada por mi costumbre" usa la sinécdoque costumbre en lugar de la persona. Pero al ser "costumbre" algo abstracto y característico de la personalidad, por estar tan cerca, quiero decir, de la persona misma, incluso

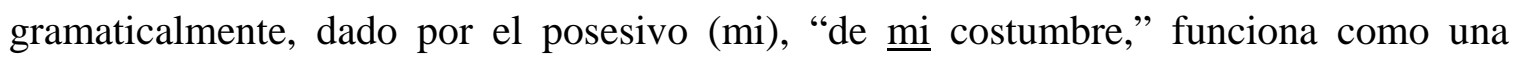
repetición retórica que no esconde ningún otro recurso que la pura decoración. Es el gasto gratuito a que se refiere Sarduy (La simulación 16), sólo que en este caso funciona como parodia del estilo narrativo que incorpora el autor.

Otro tanto sucede con la oración "Para no cansar la expectativa." Oración de recurso burdo y hasta elemental en términos de poesía, donde se opera una sustitución parecida a las estudiadas minuciosamente por Borges en "Las Kenningar." Todo el tramo de texto que me ocupa está construido sobre las mismas simetrías sintácticas. Un uso doble de sustantivos que alargan la narración por medio de transitividades que mediatizan la narración: "No quise determinarle rumbo a esa caminata; procuré una máxima latitud de probabilidades para no cansar la expectativa con la obligatoria antevisión de una sola

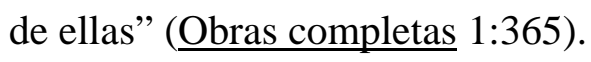

Borges podría haber solucionado la frase con algo así como: "Quise caminar sin rumbo; procuré las mayores probabilidades, para no reducir la expectativa con alguna 
previsión." Se ha reducido la frase de veintisiete palabras a dieciséis. Por supuesto que no pretendo competir con el genio de Borges; sólo intento llamar la atención sobre un recurso deliberado que parodia cierto estilo barroco. Acaso esta yuxtaposición de sustantivos complementarios, rumbo-caminata, latitud-probabilidades, espectativaantevisión nos refleja internamente en el texto, esa eternidad a que se refiere la historia del autor.

Por otro lado, este recurso apunta a la superioridad del lenguaje sobre la propia ciencia o historia. Todo se reduce a una bella retórica, a ese hedonismo que he mencionado. El texto nos dice que todo gira en torno al lenguaje y en eso radica su belleza. Borges, preocupado siempre en la trascendencia de la obra, nos aporta una clave interesante:

Virtualmente, Quevedo no es inferior a nadie, pero no ha dado con un símbolo que se apodere de la imaginación de la gente. Homero tiene a Príamo, que besa las homicidas manos de Aquiles [. . . Franz Kafka, sus crecientes y sórdidos laberintos [. . .] Góngora o Mallarmé [ . . ] perduran como tipos del escritor que laboriosamente elabora una obra secreta. $(2: 38)$

Borges ha creado un símbolo y es la posibilidad de llenar todos los espacios con la ficción verbal, con ese artificio a través del cual el propio autor percibió los textos sagrados, la historia o la ciencia.

En este sentido que hemos visto se da el barroco en Borges: en el abuso de las yuxtaposiciones que construyen la tramoya pre-argumental desde la cosmovisión poética, lo esotérico, lo recóndito, y por la repetición histórica en tanto movimiento elíptico de su 
narración. También es neobarroca la exhibición de los recursos fictivos que logran crear la verosimilitud y la ilusión dramática. El barroco en Borges está dado por esa narración que siempre vuelve al punto de partida que no es tal, y esa elocuencia de gasto gratuito, esa ley de disfrazamiento puro de la que habla Sarduy (La simulación 16), donde la lógica literaria y la belleza del discurso rigen. La jerarquización del sentido hedónico (y helenístico) de la literatura, por sobre otra intención cualquiera, es una premisa y una finalidad en Borges.

El parangón a este recurso borgeano se halla en la penetración lezamiana definida por la frase "sólo lo difícil es estimulante" (La expresión 49). Esta frase define las funciones autofictiva y hedónica de la literatura, en la axiología lezamiana. La escritura de estos autores nos dice que la literatura puede crear un universo total, válido en sí mismo, y sin necesidad de justificarse a través de una utilidad social. Borges y Lezama pertenecen a una elite culta que dialoga en sus textos con la literatura universal. El refinamiento de un arte barroco resulta productivo desde esta posición.

c. - La perspectiva microespacial y la metaforización barroca.

En Borges, la yuxtaposición barroca es la vista en "La doctrina de los ciclos," en la retórica barroca o el barroco de la demostración. Esta es la técnica que realmente nos enseña el recurso pertinente en Borges y la que se usa con más generalidad en el interior de sus textos. En Lezama también existe otro recurso barroco que define mucho más nítidamente su estilo. Eso que he llamado metaforización barroca y que paso a describir. Veremos esa metaforización barroca en función de la poética. Se observará que esta forma de lograr el barroco es polarmente complementaria al barroco por yuxtaposición borgeano. 
En las páginas que siguen me dedicaré a revisar la metaforización barroca de la que he hablado en Lezama. El estilo de Lezama es compacto, denso, sus sintagmas y oraciones escapan a múltiples sentidos, mientras que cada concepto es también altamente polisémico. Si el vocablo de Lezama se define por la polisemia, la estructura lógica de Borges se define por la polivalencia. Recupero la idea de perspectiva microespacial en Lezama que sirve de soporte a su barroco metafórico; mientras que la perspectiva macroespacial en Borges sirve de soporte a su barroco por yuxtaposición. Esta yuxtaposición a que me refiero es sintagmática. No es el recurso de enumeraciones caóticas y condensaciones que hemos observado hasta ahora en ambos autores.

El barroco en Lezama es mucho más consustancial y constitutivo como veremos más adelante, pero tiene también sus orígenes históricos. Ese barroco marginal a que se refirió González Echevarría: "Para el americano, el barroco [. . .] es un arte marginal como él” (64), es marginal en Lezama por ubicarse éste en el mismo borde respecto a las elites de poder que le circundaron y a la inmanencia represiva de su tiempo. La siguiente cita nos ayudará a entender estas circunstancias. En el artículo "La poesía del encuentro en Las miradas perdidas, de Fina García Marruz" sobre esta escritora, perteneciente al grupo Orígenes, al igual que Lezama, Emilio de Armas explica: "Aquel esplendor interrumpido de la cultura criolla es evocado por un grupo excepcional de poetas y pintores del siglo $\mathrm{XX}$, pero ahora en imágenes fragmentadas, [. . . este noble y patético esfuerzo por oponer a la frustración de lo contingente la realización de lo esencial engendra un nuevo momento de esplendor en la cultura cubana" (2).

En el centro de ese esplendor se encuentra Lezama y en esa estética de "imágenes fragmentadas" está su perspectiva microespacial, inicialmente nutrida por "aquella 
aventura 'sigilosa"' (2) que lo circunscribe al vórtice del embudo donde confluye lo súbito lezamiano. Abundando en esa cosificación insular de la Cuba de los 40, agrega De Armas: "[. . . ] los vitrales, los sillones de mimbre y los patios interiores abundan en la plástica cubana de los años 40, como si a la estridencia de una vida urbana donde la violencia política se iba abriendo paso cada vez con más ímpetu, aquellos artistas quisieran oponer el ideal de una máscara que su amor convertía en valedera" (3).

He expresado anteriormente que el barroco en Lezama es forma de expresión auténtica y es también una necesidad de ocultar ciertas claves. Las citas anteriores apoyan esta tesis. El barroco es camuflaje, en cuanto necesidad de mantener una voz coral que se sumerge en los escombros de la futuridad cubana, postergada por la violentación de la sociedad civil. Esta voz coral se confunde en sus caleidoscópicas geometrías citadinas, para florecer como arte propio. A esos textos de Eliseo Diego, En la calzada de Jesús del Monte y Por los extraños pueblos, a que se refiere Emilio de Armas como "aquel ahondar en la geografía interior de la isla, que fue parte principal de la aventura de Orígenes" (2), se suman muchos textos de Lezama.

Algunos poemas de Lezama son elocuentes en darnos esta visión "fragmentada," esa "geografía interior" que en mi estudio sobre poética articulo dentro de una perspectiva microespacial. Del libro Enemigo Rumor de 1941, tenemos "Una oscura pradera me convida". Lezama nos presenta la topografía citadina desde la más desautomatizada mirada. Aclaro que topografía citadina no significa en Lezama inmediatez, todo lo contrario, a través de ese arsenal sígnico urbano se teje una metaforización meta-metafórica, más que metaliteraria: "Una oscura pradera me convida/ sus manteles estables y ceñidos,/ giran en mí, en mi balcón se aduermen./ Dominan su 
extensión, su indefinida/ cúpula de alabastro se recrea" (1-5)(Poesía 86). Las palabras claves, balcón y cúpula nos regalan un ápice de contexto.

Sin intentar un análisis más profundo en la interpretación de estos versos ahora, me interesa llamar la atención sobre la mirada que crea esa magia dentro de las posibilidades limitadas del espacio; pero apoyada en su propia mitología espacial. Es decir, el verso parte de la observación que se hace de cierta topografía citadina. Esta topografía a su vez envuelve al yo poético, "giran en mí, en mi balcón se aduermen”. El momento en que el yo poético aparece con más fuerza es el que se usa para dar las claves que ubican a éste. El poema es un ejemplo de esa perspectiva microespacial donde el neobarroco sirve de molde a una imaginación que desborda el espacio. Otro poema de Enemigo Rumor es "Como un barco". Lezama dice: "Después de las aguas que van invadiendo/ los sentidos, la guirnalda y las lámparas" (22-23)(97). Aquí se vuelve a repetir el paisaje urbano, y de nuevo, el minimalismo lezamiano jerarquiza una mirada objetual.

En 1949 se publica el libro La fijeza en él aparece el poema "Pensamientos en La Habana" de un alto grado de complejidad. En este poema Lezama logra una metáfora mucho más atrevida y su sistema se percibe en la unicidad del estilo: "Mi espalda se irrita surcada por las orugas/ que mastican un mimbre trocado en pez centurión,/ pero yo continúo trabajando la madera/ como una uña despierta," (211-214) (Poesía 152). La fijeza en Lezama tiene una connotación intrínseca. Según Sarduy, el libro es clave en la poética de Lezama: "Está, la vida de Lezama, sellada por lo que fue también el centro de su sistema poético y título de su obra clave: La fijeza. Y aún Más: el encierro, una persistente inmovilidad [. . .].” (“Carta de Lezama” 35). 
Ya se considere la visión lezamiana alimentada por aquella "geografía interior," por la "imagen fragmentada," o por la fijeza, lo cierto es que esa perspectiva minimalista, modesta, en la que el neobarroco viene a explotar las posibilidades de expresión y a compensar con la imaginación una topografía lata, está en el centro de la estética de Lezama. En el poema "El pabellón del vacío" fechado en 1976, 35 años después de "Una oscura pradera me convida" y 27 años después de "Pensamientos en La Habana," Lezama reitera en la imagen de la uña, aquella "uña despierta" que apareciera en "Pensamientos..." (152). Como si se hubiera acostado a dormir por 27 años y ahora retomara el poema donde la uña trabajaba en la madera y nos dice (cito sólo el final después de reiteradas imágenes de la uña sobre la mesa, en el papel, etc.):

Araño en la pared con la uña,

la cal va cayendo

como si fuese un pedazo de la concha

de la tortuga celeste

¿La aridez en el vacío

es el primer y último camino?

Me duermo, en el tokonoma

evaporo al otro que sigue caminando. (67-74) (Poesía 396)

Esa fijeza lezamiana, ese enclaustramiento desarrolló indiscutiblemente una mitología urbana, mental, que reside en lo elíptico del barroco, en esa fuerza descomunal de la imagen que se va entretejiendo, llegando a la infinitud de un micromundo en el cual siempre cabe descripción. Lezama va reduciendo su perspectiva, va centrando el foco del poema hasta reducirlo a ese punto físico que se entremete en la cal de la pared, pero una 
vez que entra en dicho mundo, evapora al otro y se abre un nuevo universo. El fenómeno es idéntico, no digo similar, a la difracción. De esto hablaré en su momento.

Ahora quiero concluir con dos declaraciones. La primera es que este recorrido por algunos poemas de Lezama nos ha demostrado esa intención de camuflaje, ese estilo lezamiano que esconde ciertas claves mediante su escritura. Se recupera una Habana inexistente a través de la mirada, a través de esos vitrales, sillones, patios de los que habla Emilio De Armas y que en Lezama son sumamente abstractos. La jungla imaginaria acude al panteón doméstico donde "antílopes, serpientes de pasos breves" (Poesía 86) acuden a la hora del baño. El segundo elemento que quiero enfatizar es la evolución de la microespacialidad. Si al inicio, Lezama, conjuntamente con muchos del grupo Orígenes, se oculta en una Habana estética, pasada, vigente en la arquitectura como un residuo recuperable, después esa ocultación se convierte en sistema, en identidad, en exordio de un estilo propio.

Luego el neobarroco que ha logrado Lezama, que ha construido para sí, después de desarticular la originalidad del barroco español, a partir de su teoría del eclecticismo, es también identidad, pertenencia. Es la forma de insertarse en la conciencia social con un sentido de procedencia y de proyección. La marginalidad del neobarroco y la marginalidad de Lezama entran en suave simbiosis. Para James López: "Hispanoamérica se crea y estará marcada irremediablemente por la cultura barroca española, en la forma tanto de una cultura impuesta [. . .] como de un medio subversivo" (López 33). El barroco como corriente de pensamiento y síntesis cultural es absorbido en América y apropiado por ésta. Según el crítico, en el modernismo el "sujeto hispanoamericano renacerá a la plenitud de expresión [. . .] su habilidad por conformar (sic) lo propio a 
partir de lo foráneo se politizará y se convertirá en un arma de diferenciación: nuestra perenne obsesión por la identidad" (López 34).

Lezama, con el beneficio de ubicarse después del modernismo, asiste a la crítica de esta etapa de renacimiento a "la plenitud de expresión" guardando cierta distancia, quizás intencionalmente. Pero a la vez connota esa apropiación del barroco, y más que esto, acusa la retroalimentación europea de un neobarroco ya hispanoamericanamente endémico:

En las mejores calidades del artista americano, cartas o crónicas de Indias, churriguera, barroco jesuita o romanticismo descriptivo (el de Whitman o el de Martí)(sic) se alcanzó un signo de justificación en el que sucesivo y súbito jugaron fiel y raya. Y así es necesario igualar en el barroco los regresos de los jesuitas españoles en Italia con los envíos americanos a España, y que ya no regresarán. En la sacristía de Cartuja de Granada, se ve las degeneraciones iridiscentes de un barroco que resuma lo mozárabe que trabaja sobre la plata suave y blanda de Indias. Así cuando el zahorí de siempre intenta que el artista americano se vuelva hacia la luna del arte primitivo, olvida que no puede existir para el americano primitividad del

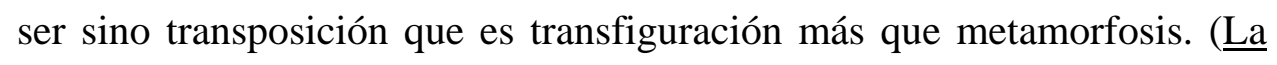
materia artizada 265-66)

Ese recurso de transfiguración, término semejante al expresado por Sarduy de "disfrazamiento puro" ( carnaval barroco hispanoamericano. El barroco deviene apropiación que se convierte en identidad, en lenguaje propio. 
En esa polea transmisora que repite los patrones culturales o eras imaginarias, para repetir el concepto lezamiano, se da la creación. Lezama se ubica en el centro de esta polémica para establecer su identidad cultural a partir de un barroco que busca desde sus orígenes y que redefine como universal, a partir de su vuelo temporal. López nos dice, en el citado artículo: "Pero tal y como toda revolución lleva las huellas genealógicas de su patrón histórico, el espíritu que palpita detrás del renacimiento modernista proviene de su antiguo opresor, cosmovisión íntimamente relacionada [. . .] con la matriz castellana, el llamado Barroco proporcionará las armas para lo que Lezama llamaría más tarde 'el arte de la contraconquista' (La expresión americana 34)” (López 2).

Pero si bien es cierto que la revolución hispanoamericana o a nuestro propósito, el neobarroco como revolución del lenguaje, lleva "las huellas genealógicas" de la "matriz castellana," también es cierto que Castilla repite con América el trauma materno de su pasado mudéjar o mozárabe. El propio castellano y su barroco llevan constitutivamente ese sentido foráneo y ecléctico. Es también mozárabe el ocultamiento del cuerpo humano y la rebuscada forma de la representatividad del amor en la literatura y la pintura. A este sentido foráneo del mismo barroco español se remite Lezama para desmarcar el barroco como entidad marcada temporalmente, o como estigma definidor de un periodo de la cultura. Lezama, al situar en España (en la sacristía de Cartuja de Granada) ese barroco que "resuma lo mozárabe," generaliza el barroco y vuelve a darle, a partir de ese recurso de anular la referencialidad absoluta, un carácter universal.

Lezama, en una demostración asombrosa de síntesis barroca, ha colocado en un mismo cuadro pictórico el cristianismo, lo musulmán y el indio americano, demostrando lo barroco del hecho en sí. Esta hibridez se da dentro de las propias instituciones de poder 
social de la España que coloniza. Como se deduce de la cita anterior de Lezama, la propia cuestión de la identidad es heredada desde la mera conquista, con las poblaciones andaluzas y sureñas que fueron de alguna manera desarraigadas de su centro, ya margen, desde España. Esa marginalidad marca la incipiente cultura del nuevo mundo.

El barroco en Lezama es marginal por su posicionamiento respecto a las elites de poder. Me refiero a las elites políticas, sociales, culturales e históricas como he venido diciendo. Pero también es liminal por el carácter germinal, de substrato de su poética misma. El hecho es que en Lezama el barroco cuenta con un esfuerzo de sistematización, con una estructuración teórica de complejo plasma, por no decir textura, que no se había visto antes. Para Gustavo Pellón esta sistematización es un tanto dudosa. Acerca de este sistema Pellón comenta: "Critics generally accept Lezama's claim that he evolved a poetic system, and attemps have been made to codify his terminology. Any such codification, however, is rendered difficult (if not ultimately impossible) because there is much more poetic insight than critical systematization in Lezama's literary system" (46).

Es cierto que existe en Lezama un alto nivel de lo que el crítico define como "poetic insight", hasta el punto que sostengo que en Paradiso la estructura imaginística domina la estructura narrativa. Esta fuerte presencia de la condensación metafórica, en función de una compleja red de imágenes, ha llevado a Julio Cortázar a cuestionarse la condición de novela de Paradiso, como hemos citado oportunamente (136). Sin embargo, el intento de sistematización está ahí. Es un intento de sistematización a partir de la evolución y desarrollo de la imagen. Lezama desarrolla ampliamente sus ideas en Las

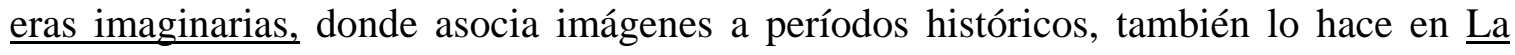


expresión americana, donde busca los orígenes de la expresión de un continente a partir de una sistémica mirada a las metáforas e imágenes de sus expresiones artísticas.

Estoy de acuerdo con el crítico, en definitiva, que la codificación de dicho sistema es una oscura tarea. Pero pienso que sí existe suficiente sistematización crítica en el sistema literario de Lezama. No existe, en mi opinión, poeta moderno que haya teorizado más sobre su sistema poético. Lezama, al igual que Vico, indaga en un pensamiento por imágenes e incluye a dicha imagen como el elemento central de tal sistema, de ahí la complejidad (Álvarez 23). Los conceptos en Lezama son metáforas en evolución porque su sistema intenta ser prelógico. Uno de los poemas claves en describir el arte poética de Lezama, "Muerte de Narciso," nos adentra en estas metáforas transformantes. Veremos cómo en el autor de $\underline{\text { Paradiso }}$ existe una metaforización barroca que designa la realidad de otra manera, porque realmente ve otra realidad, hasta tal punto que la crea. El barroco en Lezama es creacionista y lo he definido "metaforización barroca," en contraste con el barroco borgeano que se da por yuxtaposición.

Entrando en la demostración de la metaforización barroca, comienzo con un análisis del poema "Muerte de Narciso," para ver los primeros escollos barrocos en la incipiente voz de Lezama; continuaré con un estudio de sus poesías y ensayos posteriores para anotar planteamientos teóricos y evolución; luego revisaré los relatos con el objetivo de establecer una comparación con Borges en un mismo género literario; y finalmente me detendré en $\underline{\text { Paradiso }}$ y $\underline{\text { Opiano Licario }}$ para demostrar otros elementos como la carnavalización de la literatura, el montaje, la plasticidad y otros recursos retóricos.

Aunque el binomio yuxtaposición/ metaforización es cierto respecto a las distintas formas de componer el barroco; éste se da como una generalidad, en ocasiones ambos 
estilos coinciden, como he mencionado. El estilo de Lezama comenzó a inquietar ya desde su aparición en la palestra pública con su primer poema "Muerte de Narciso." La concatenación metafórica y las alusiones que se entretejen en este poema son novedosas. Tienen, al igual que en Borges, lo ecuménico que rescata el archivo cultural total; pero existe en Lezama una osadía sintáctica no intuida anteriormente. A eso se refería Cintio Vitier cuando calificaba su escritura de "barroquismo no previsible" ("La poesía" 47). En el mismo ensayo Cintio Vitier sitúa a Lezama en relación con sus coetáneos: "Su espacio y sus fuentes no estaban en relación esencial ninguna con la circundante atmósfera poética" (47).

En este ensayo citado Cintio Vitier parte de "Muerte de Narciso" explicando las referencias universales en que se basa la escritura de Lezama. A pesar de la diferencia de estilo, esta escritura tiende con Borges el puente cultural; comparte la irreverencia por toda fuente de saber y la apropiación paródica de esa realidad literaria. El socorrido y citado comienzo del poema en cuestión nos lo demuestra:

Dánae teje el tiempo dorado por el Nilo envolviendo los labios que pasaban entre labios y vuelos desligados.

La mano o el labio o el pájaro nevaban.

Era el círculo en nieve que se abría.

Mano era sin sangre la seda que borraba" (1-6) $[\ldots \ldots \ldots \ldots \ldots \ldots,(\underline{\text { Poesía }} 75)$.

Lezama utiliza el material conocido por la cultura para garantizar otra vez la recepción; pero de ahí elabora su propia fábula. 
Sin pretender repetir un análisis del poema, me detendré en señalar esos recursos barrocos que definen desde un inicio la metaforización lezamiana tan característica y $\tan$ vadeada. Ya desde el inicio del poema, anota Cintio Vitier, Lezama escribía "el verso más sorprendente con que haya empezado jamás un cubano un poema, el inicio lejanísimo y sin embargo familiar, [ . . . . ("La poesía” 47). Lezama ha recorrido tras ávida lectura, la historia cultural de la humanidad. Su perspectiva, especializada en la evolución de las imágenes, en esas eras imaginarias que supo observar, le ha dado la visión totalizante, la visión del cúmulo. Esta perspectiva puesta en función de su afán estético, en el que la búsqueda de la poesía está por encima de todo reflejo gratuito de la realidad, produce ese verso "lejanísimo y familiar" a que se refiere Cintio Vitier.

El primer verso del poema, "Dánae teje el tiempo dorado por el Nilo" (47) nos remite a la mitología. La simple elección nos afirma el gusto por lo helenístico y por lo universal. La distancia a que estamos todos por igual, respecto a lo helenístico, lo afirma como código paradigmático de la literatura. Esto es un elemento en común con Borges y un rasgo del barroco. Lezama se ha retirado de toda la inmanencia insular y topológica, para establecer su axiología en términos estéticos. Semejante tratamiento se encuentra en los relatos de Lezama.

Sin alejarnos del análisis de "Muerte de Narciso," observemos el inicio de otros tres textos de ficción. El relato "El guardián inicia el combate circular" comienza con una topología desconcertante y un barroco burlesco: "Lo hecho para perseguirse comienza con un maullido. Y la esterilidad de los vacilantes senadores descorre ese maullido como trasciende la joven cabeza de tortuga entre la yerba antediluviana" (Relatos 83). Es un comienzo absolutamente descontextualizador que juega con el oximoron que hemos visto 
en los textos de Borges. Dichas estructuras oximorónicas están dadas aquí por “joven cabeza" frente a "yerba antediluviana" y por la contraposición de los conceptos "trascendencia" y "antediluvio".

Pero sólo viene a caso observar este ejemplo como reforzamiento de ese afán por instaurar con la imagen un espacio mítico, no ubicable en las referencias del lector contemporáneo a Lezama. El barroco burlesco se produce aquí por la yuxtaposición de elementos. Haciendo un inventario semántico de conceptos tenemos: maullido, senadores, cabeza de tortuga, yerba. Esta nueva modalidad de enumeración caótica, desplegada despaciosamente a través de la cadena discursiva y no simplemente separada por comas como es frecuente en poesía, sigue la idea de la metaforización barroca. Los términos están yuxtapuestos, pero la yuxtaposición está mediada por el devenir sintáctico, por el avance de la narración. En lugar de enumeración caótica hablaría de observación caótica, de recorrido caótico.

Otro ejemplo de inicio que nos refiere al código metaliterario se observa en “Cangrejos, Golondrinas". Lezama de nuevo se ha retirado de toda la inmanencia insular y topológica para entregarnos una topografía mito-teológica "Eugenio Sofonisco, herrero, dedicaba la mañana del domingo a las cobranzas del hierro trabajado" (93). La acumulación de ciertas claves nos llevan a interpretar el texto en conjunto, de esta manera mitológica, si bien es cierto que cada elemento por separado puede ser de significado neutral o nulo respecto a la topografía. Primero, un nombre casi griego, Sofonisco. Luego, el propio oficio de herrero es un oficio antiguo, y por último el vocablo cobranza unido a la sintaxis barroca nos remiten a ese tema mito-teológico a que me he referido. 
Si este último ejemplo no es feliz, véase el relato "Pífanos, epifanías, cabritos": "Se ponían claridades oscuras. Hasta entonces la oscuridad había sido pereza diabólica y la claridad insuficiencia concreta de la criatura" (115). Este inicio parece remitirnos a los temas teológicos que hemos mencionado. Este tercer ejemplo, además, aclara el contexto del anterior. Los temas de la luz, el diluvio, la herrería ya van construyendo un mapa referencial. Lezama llega a los orígenes. Tanto en "Muerte de Narciso" donde se teje el origen temporal, como en la novedad terrígena de "El guardián inicia el combate circular," o el incipiente mundo comercial expresado al inicio de "Cangrejos Golondrinas" o, incluso, la propia creación de un mundo de luz y sombras recién definido, expresado en "Pífanos, epifanías, cabritos," nos muestran conjuntamente esta intención genésica que viene unida a un estilo también novedoso. Un neobarroco que ha unificado (inventado) tema, topografía y estilo.

Posteriormente me detendré en los relatos de Lezama y en su semejanza temática y estilística con los relatos de Borges. Por ahora me interesa hacer ver que el inicio del poema "Muerte de Narciso" no es un caso aislado en la poética lezamiana. Ese verso "lejanísimo" y "familiar" a que se refiere Cintio Vitier tiene los dos componentes centrales que son ejes de este estudio. El verso de Lezama es lejanísimo por su categoría de término no marcado respecto al referente inmediato. Su nueva contextualización lo acerca a la metaliteratura. Es un estilo que se construye desde las imágenes literarias preexistentes, desde los códigos culturales.

Por esa razón el verso de Lezama es lejanísimo, porque los asideros para su clasificación sólo pertenecen al sistema Lezama que se irá entregando poco a poco. Lezama escritor, en su vida, actúa como un narrador de la realidad que ahora es ficción. 
Nos entregará la información y esas claves necesarias a medida que su sistema se vaya narrando. He aquí de nuevo el paralelo filogenético con Borges. Me he referido en la introducción a una relación biyectiva en la escritura de Borges donde la simplificación que opera la escritura de madurez, también tiene lugar en cada relato particular. Semejante relación guarda el proceso sistémico de Lezama. "Muerte de Narciso" o para el caso, los inicios de relatos presentados comienzan con la enunciación de un origen y a partir de este se desarrollan los elementos del sistema. La evolución de Lezama, como escritor, sigue esa misma trayectoria.

Por esta otra razón, lo que antes era lejanísimo, es familiar. Lezama escribe desde su sistema poético y al entrar en él constatamos la familiaridad, la cercanía de su propia escritura, de su sicografía desplegada en texto. Lezama comienza con los orígenes, o más bien va a los orígenes para redefinir una mitología. Lezama a la vez se aleja también del código canónico descentrando el mito. Al ubicar a Dánae en el Nilo tejiendo el tiempo, nos recrea el mito clásico, lo reconstruye. Dánae es fecundada por Zeus en la mitología clásica. En la mitología lezamiana teje el tiempo perteneciente a Cronos y anterior al propio Zeus. No sólo se da acá el gusto por lo helenístico como signo barroco; sino que se transpone la mitología clásica mediante una especie de mitopoesis marginal que pertenece al neobarroco y por consiguiente lleva su carga paródica y plástica.

La plasticidad y la sensualidad del verso son indistintamente novedosos respecto a los usos de la época. Lezama confunde con los signos de un arte poética que pudiera pensarse modernista por lo exótico, parnasiano por lo sinestésico, mágico realista por lo exuberante y telúrico de la frase "la mano o el labio o el pájaro nevaban;" pero que es en sí neobarroco, por el uso paródico y sincrético de todos estos tonos, así como por cierta 
sensualidad que llega casi a lo erótico. Volvemos al planteamiento de Sarduy sobre su teoría del gasto, del derroche gratuito. El neobarroco es un lenguaje puramente fictivo en este texto.

El narrador del verso "la mano o el labio o el pájaro nevaban” (oesía 47) declara su equisciencia al no precisar de dónde proviene la causa cuyo efecto es la nevada. De acuerdo a los postulados de este estudio y fiel al idealismo y a la fenomenología lezamiana, elementos que ambos autores en cuestión comparten, no se necesita aquí definir una verdad sobre la causa, conocer el efecto es regalo suficiente. Además, según los postulados de Borges y Lezama las causas pueden ser varias e incluso simultáneas, muchas veces imposibles de determinar. Este recurso postmoderno, es una de las características del neobarroco de Lezama que se da en varias ocasiones a través de una pregunta al lector y en otras por el uso del condicional para anular la direccionalidad causal.

Estos dos primeros ejemplos de equisciencia narrativa a través de preguntas al lector son de "Muerte de Narciso." Se puede pensar que la pregunta es la consabida figura retórica. Pero en este caso, al ser formulada por la voz poética que supuestamente narra lo acontecido y por tanto conoce el pasado y el futuro, por un lado; y por otro, al ser una pregunta continuación del argumento e incrementada en su duda por ese tal vez, se destruye la ilusión narrativa, a la vez que se logra un nuevo efecto estético: “¿No se apresura tal vez su fría mirada/ sobre la garza real y el frío tal débil/ del poniente, grito que ayuda la fuga/ del dormir, llama fría y lengua alfilereada? (13-16) (Poesía 76). Por supuesto que el narrador intenta reflejar la indagación de Narciso, pero no deja ser cierto que la equisciencia también alude a la disolución causa/efecto. El segundo ejemplo nos 
ayuda en este sentido: “¿No es la curva corintia traición de confitados mirabeles,/ que el espejo reúne o navega, ciego desterrado?” (58-59) (Poesía 78)

En el capítulo dedicado a la ficción de racionalidad veremos con amplitud estos recursos, en función de un juego con el lector, elemento que es mucho más obvio en Borges y más sutil en Lezama, por la complejidad metafórica y el vuelo de sus referencias culturales. Ahora los recursos nos viene a ilustrar ese barroco autocentrado que desconoce la causa y se regodea en el puro goce estético. Estamos en presencia de un barroco puramente fictivo que se aleja de toda inmediatez y a partir de un código mitológico conocido recrea su propio mito.

Cito ahora los ejemplos, también de "Muerte de Narciso", donde el uso del condicional anula la direccionalidad causal: "Si se aleja, recta abeja, el espejo destroza el río mudo./ Si se hunde, media sirena al fuego, las hilachas que surcan el invierno/ tejen blanco cuerpo en preguntas de estatua polvorienta" (Poesía 79). Narciso se va haciendo en el poema, pero el poema tiene varias posibilidades y no se define dentro de este segmento cuál ocurre. Todas las posibilidades se postulan y se dejan abiertas al lector, como posibles indagaciones de Narciso, de Narciso lector. Ésta es, en el originalísimo estilo lezamiano, la idea explícita en "El jardín de senderos que se bifurcan". Como he mencionado antes, Borges lo presenta mediante una construcción, en Lezama se encuentra en forma de imagen dentro de la cadena metafórica. Debe mencionarse que "Muerte de Narciso" fue publicado por primera vez en 1937. Por eso, en este estudio hablo de poéticas complementarias y no de influencias en un sentido u otro.

Véase un segundo ejemplo dentro del propio poema "Muerte de Narciso": "Si atraviesa el espejo hierven las aguas que agitan el oído./ Si se sienta en su borde o en su 
frente el centurión pulsa en su costado./Si declama penetran en la mirada y se fruncen las letras en el sueño" (81). Éste es un caso más obvio de ese poema abierto a la causa posible, a ese "si" condicional, como una de las variantes a escoger por Narciso. Es cierto que cada causa aún tiene su efecto, pero la multiplicidad de posibilidades mantiene el poema abierto. El recurso se repite en otros poemas posteriores, entre ellos "Encuentro con el falso" de Aventuras Sigilosas, ocho años después: "Si al caminar, el hijo vuelve como una piedra al arco en flor./ Si se camina, alguien se cuelga: yo soy su hijo." Y versos más adelante Lezama agrega: "Si por la verja pasas la mano cuelgan las hojas de un cordel lacio./ Si por la verja del que pasea por los oscuros pasas la mano,/ el hijo falso como una escoba cuelga vejigas que ya han sonado, [...]." (133).

Con este recurso Lezama representa prácticamente en su escritura la idea de la poesía como algo prelógico: "Es para mí el primer asombro de la poesía que sumergida en el mundo prelógico, no sea nunca ilógica. Como buscando la poesía una nueva causalidad, se aferra enloquecedoramente a esa nueva causalidad" (Eras imaginarias 33). Lezama, desde sus inicios, con "Muerte de Narciso," se compromete con esta definición de la poesía. Su búsqueda de los orígenes marca su poética y está explícita e implícitamente plasmada en sus textos. Su neobarroco reside en esa cuerda que trata de unir el planteamiento teórico de incoación poética y su sentido ecléctico de la cultura con una percepción compleja y postmoderna de la realidad.

Ya se ha sugerido en este estudio que la causa psicológica de la perspectiva microespacial en Lezama se puede encontrar en su enclaustramiento físico e ideológico. Este genera la necesidad de crear de él un hábitat literario. Asimismo, podemos decir que la mayoría de sus focalizaciones reflejan un imaginario distorsionado de ese minimalismo 
sensorial. A su vez, la causa del barroco por metaforización se puede encontrar en el desborde imaginativo del continente espacial. En otras palabras, en Lezama existe una discordia entre continente y contenido; entre significado y significante. Para poner los cuatro términos de la demostración en una lógica continua, digamos que las condicionantes sico-ideológicas desarrollaron una hipersensibilidad microespacial y esta a su vez, se vale de la metaforización barroca como recurso, para expresarse como sistema poético. Mediante la creación de un "sistema poético" Lezama ha creado su teoría, una "teoría poética" que depende de la propia interpretación que el autor da a esa poesía. Tal teoría intenta reflejar un mundo distorsionado por la perspectiva del "sensor" (Lezama). En este sentido se da el intrincado oximoron lezamiano (teoría poética) y lo elíptico de su sistema que parte y llega al mismo punto.

La perspectiva microespacial lezamiana está presente visiblemente en toda su obra; se puede ver en sus novelas, en los poemas y en los ensayos. En estos últimos la microespacialidad se explicita en la forma sui generis con que Lezama mira el arte y ese borde por el que comienzan sus análisis estéticos. La perspectiva microespacial es anterior al barroco en Lezama. Es, por así decirlo, lo que da causa a ese barroco. Tal perspectiva no coincide con el barroco propiamente dicho; sino que se deposita en la cadena discursiva mediante metaforizaciones neobarrocas. Por ser dicha perspectiva causa del barroco lezamiano, y por estar en el centro de su poética, la incluimos en esta sección que inicia la discusión sobre metaforización barroca.

Antes de pasar al análisis textual que demuestra la perspectiva microespacial en la poesía, menciono algunos poemas donde se puede constatar. Indico el libro en donde se encuentra el poema y la fecha de publicación del mismo a modo de enfatizar lo constante 
de este aspecto que reviso. Los poemas son "Pensamientos en la Habana" (147) del libro La fijeza (1949); "Venturas criollas" (215) del libro Dador (1960) "La prueba del Jade" (poemas no publicados), “Agua oscura” (349-51), "Fábula de Dánae” (389), “La escalera y la hormiga" (390) y "La mujer y la casa" (393), estos últimos son del libro Fragmentos a su imán (1977). En todos estos poemas se da la perspectiva microespacial de una manera u otra. Algunos parten de la focalización de un objeto y de ahí regeneran toda una proliferación barroca, otros recrean un ambiente doméstico y recorren la geografía interior, magnificando objetos y amplificando la relevancia de estos mediante resemantizaciones y condensaciones metafóricas. En ocasiones se observa lo que apunta Mark Richard Couture: “The poem's linguistic proliferation epitomizes the barroque period's capacity to translate feeling into sign or symbol" ("El agua” 22).

A modo de ilustración gráfica sobre la microespacialidad, comienzo aleatoriamente por un poema del libro Fragmentos a su imán. El crítico Luis Antonio de Villena, analiza un fragmento del poema "Vi". Cito primero el fragmento del poema: "Vi lo que no vi,/ pero, ¿el ojo?/ Precisó” (Poesía 365). Tenemos la perspectiva microespacial en esa focalización que el ojo, el oído, los sentidos tratan de lograr al acercarse al objeto para deformarlo o distorcionarlo con la caricatura. De Villena discute lo que él denomina lo chamánico en Lezama y dice, refiriéndose a poemas que "analizan objetos": "Es como si sobre tal objeto se aplicase una muy potente lupa y ello provocase una sucesión encadenada de imágenes" ("Lezama Lima” 67). Se genera la eclosión desde el objeto. En este fragmento citado el ojo focaliza, se enfoca nítidamente como una cámara fotográfica, porque existe una duda epistemológica sobre el hallazgo. Incluso, los signos de 
interrogación que rodean al ojo, nos dejan la duda, de si fue realmente el ojo quien precisó: "Pero, ¿el ojo?/ Precisó” (Poesía 365).

Esta duda apunta al escepticismo epistemológico lezamiano (borgeano) que en Lezama sustituye el universo, la Historia, el tiempo, por una sustancia mínima. En mi esquema demostrativo, Lezama explora y describe el micromundo y Borges el macromundo. Pero continuando con el poema "Vi," dice el autor seguidamente: "El silencio mascullaba las hojas,/ crecía como un ombligo capitolino" (365). Lezama intenta penetrar ese mundo intangible, inaudible donde la materia vive, donde la vida late en una "subpercepción." El silencio para Lezama es una actividad molecular, masculla las hojas y las envejece. Quizás no percibimos esa "mascullación" pero vemos el resultado de la hoja seca a través de los días. Sucede como con la cámara de niebla y otros instrumentos que "sensan" el micromundo, sólo vemos su rastro, su transitividad. Lezama, en su percepción, regresa a la prelógica de ese proceso y lo anuncia en su propio decurso. Por esta razón la voz poética se pregunta si fue el ojo el que precisó o es la propia poesía la que denota la laboriosidad del silencio.

El silencio "crecía como un ombligo capitolino". Al acercar esa "potente lupa" de la que habla de Villena, el silencio, ahora ombligo tan grande como un capitolio, se ha dimensionado de manera que ese mundo real que percibimos compatiblemente con nuestras dimensiones humanas, está dispuesto para ser visto por nosotros los lectores. Lezama operó dos conversiones. La primera conversión fue pasar de lo invisible del silencio a lo visible del ombligo. Se pudiera pensar aquí en una conversión sinestésica. La segunda conversión es espacial. Mediante la expansión del ombligo a tamaño de capitolio se produce el salto que permite introducir la realidad en esa microespacialidad. 
El narrador lezamiano es nuestra interfase. Pasa de la perspectiva del autor (Lezama) a la "humana" para introducir nuestra realidad en esa otra realidad que el poeta crea. La metaforización barroca se dará entonces en la acumulación de imágenes que se comprimen en ese espacio inicialmente pequeño.

Una analogía válida a este mecanismo lezamiano sería el usado por la holografía. El holograma es una fotografía lograda mediante patrones de interferencia LASER que no sólo almacena la intensidad de la luz (claro/oscuro) como la fotografía convencional, sino que contiene también la fase con que llega la onda a ella. Por eso, el holograma da distintos planos visuales según desde qué ángulo se mire. Pero lo más relevante para nuestro análisis es que cada fragmento de la holografía refleja toda la realidad contenida por el conjunto, sin importar las dimensiones del fragmento. Es como si nos asomáramos a una ventana. Mientras más nos acerquemos a la pequeña hendidura, más somos capaces de ver. La técnica lezamiana tiene esa capacidad. Su barroco está en lo preñado que se agolpa en el punto espacial y se concatena con el poema todo. Esto sucede porque en definitiva responde a un sistema que le sirve de soporte.

En la teoría fractal de Benoit Mandelbrot la estructura geométrica se reproduce hasta el infinito interior. Cuando tomamos una pequeña porción del patrón y la ampliamos para estudiar su estructura aparece entonces el mismo patrón contenido en el patrón mayor, a una escala menor y así ad infinitum. En ambos ejemplos, el de la holografía y el de los fractales, la naturaleza nos proporciona una forma analógica de proceder. A diferencia de las magnitudes continuas o de las geometrías construidas a partir de las proporciones rectas, donde incluso se define a la línea recta como una circunferencia de radio infinito, la teoría fractal, aunque es un modelo tan falible como 
otros, nos explica por ahora un mundo de fundamentos barrocos, continuo y discontinuo, donde las porciones contienen ya el patrón del todo; donde cada acercamiento regenera un nuevo ciclo, como las volutas de la arquitectura barroca. La fotografía holográfica y los fractales son simples ejemplos provenientes de otra forma del saber humano, que ilustran cómo Lezama interpretó las corrientes de pensamiento de nuestra época a un nivel profundo y las expresó artísticamente mediante textos efectivos.

Revisemos ahora otro ejemplo de texto donde se vuelve a dar la perspectiva microespacial; pero con ligera diferencia al del poema "Vi" revisado con anterioridad. Este poema se titula "El pabellón del vacío," citado al inicio del estudio. Aquí el yo poético focaliza un punto minúsculo, en el cual va hurgando con la uña hasta poderse ocultar en él el poeta. Hago una selección de los momentos del poema pertinentes a esta demostración:

De pronto, con la uña

trazo un pequeño hueco en la mesa.

Ya tengo el tokonoma, el vacío,

la compañía insuperable (24-27)

$[\ldots \ldots \ldots \ldots]$

El vacío es más pequeño que un naipe

y puede ser grande como el cielo,

pero lo podemos hacer con nuestra uña (51-53)

$[\ldots \ldots \ldots \ldots \ldots]$

Araño en la pared con la uña,

la cal va cayendo (67-68) 
$[\ldots \ldots \ldots \ldots \ldots]$

Me duermo, en el tokonoma

evaporo el otro que sigue caminando. (73-74) (Poesía 396)

La evolución dimensional ha ido en sentido opuesto en este caso. En el ejemplo anterior el ombligo (el silencio) crecía y se acercaba a las dimensiones de la realidad, ahora el poeta se ha reducido y penetra por el hueco abierto con la uña y desaparece al vacío. La aseveración de que "el vacío es más pequeño que un naipe", pero "puede ser grande como el cielo" nos explica precisamente ese mecanismo de ajuste mutuo. Un ajuste de las perspectivas espaciales y cósmicas del poeta al mundo real, para que entendamos su artificio y un ajuste empático del poeta a su propia entidad microespacial.

Emilio Bejel habla de una "fuga semántica" en las conexiones lógicas de la escritura de Lezama (cit en Couture, "El agua... 23). En este caso la fuga es metafísica. En "Borges y yo" también existe una fuga: "Así mi vida es una fuga y todo lo pierdo y todo es del olvido, o del otro" (Obras completas 2:186); pero la fuga en Borges se debate con la identidad en su vestidura estética, es realmente un cuestionamiento ontológico. Lezama no se pregunta quién es, ni se discute su identidad; Lezama renuncia a un espacio y se integra a otro orden en el que encuentra el equilibrio. Emilio de Armas señala la importancia del vacío en varios textos lezamianos y su relación con el taoísmo (Poesía 394). El ajuste a que he hecho referencia, la coherencia perceptual y la forma en que esta perspectiva se acomoda a la topografía que sirve de referente al poema, son prueba de cómo el altamente estructurado sistema lezamiano viene a servirle de locus amoenus.

Reviso un último ejemplo de la perspectiva microespacial en los poemas. Ésta se encuentra en "Venturas criollas" del libro Dador de 1960. El interés en este caso es 
revisar cómo funciona la perspectiva microespacial en un poema descriptivo de una topografía rural: "La noche rellena reclama la húmeda montura,/ la yerba baila en su pequeño lindo frío,/ pues se cansa de ser la oreja no raptada./ La hoja despierta como oreja, la oreja/ amanece como puerta, la puerta se abre al caballo./ Un trotico aleve, de lluvia, va haciendo hablar las yerbas" (Poesía 215). Aquí vemos de nuevo el método holográfico donde la parte refleja el todo. A este método me había referido al final de la sección "Los raros" con el ejemplo de "Inalcanzable vuelve" (Poesía 333) y lo había comparado con un recurso semejante en los textos de Borges, por ejemplo El Sur. Recordemos que Jaime Alazraki comentaba que "el primer eslabón del cuento es así una cifra del cuento todo" (Alazraki, Versiones 31).

En el poema en cuestión la primera percepción se hace desde un lugar donde el narrador observa. Este lugar bien puede ser la puerta desde donde se observa, y la oreja y los ojos los canales por donde se recibe esa observación. Luego vemos que "la hoja despierta como oreja" y "la oreja amanece como puerta". Después de este traslado transitivo, o si se quiere, esta espiral de eje traslaticio, para usar palabras de Lezama, volvemos a la focalización inicial desde donde se percibe que "un trotico aleve de lluvia, va haciendo hablar a las yerbas". El recorrido en espiral nos ha llevado a la elipse barroca. Hay un recorrido en círculo desde donde se observa el paisaje, pero el foco se ha desplazado. Ahora ha amanecido y se observa un mundo diferente, donde las yerbas hablan, en contraste con el de la observación anterior en que "la noche reclama[ba] la humedad".

En este fragmento se da, en síntesis, el ciclo del agua. Primero el agua se evapora y está ausente, pero la noche reclama el agua y este reclamo es escuchado, pues mientras 
el agua se condensa las hojas orejas tienen noticias del proceso (quizás truenos, quizás la lluvia) y por último las yerbas experimentan la alegría del agua-montura. Sin embargo, la intangibilidad de la conjugación del amanecer y el hablar de las yerbas, nos sugiere el proceso inverso del agua levitando, o al menos apunta al próximo ciclo de evaporación. En mi opinión, la metaforización barroca de Lezama se logra a partir de la síntesis suma en la composición.

En el análisis anterior se percibe el panteísmo lezamiano, donde la naturaleza actúa como un ente vivo y dialogante. La conversación de la noche con el agua, el baile de la yerba esperando el milagro, esperando ser oreja raptada por los truenos, así como el trote de la lluvia sobre los campos, que revive a su vez y hace hablar a las yerbas, nos dan el panteísmo coagulado. Este panteísmo es uno de los elementos de la condensación metafórica barroca. El otro elemento es la estructura elíptica de los versos y el tercer elemento es la perspectiva microespacial. Esta perspectiva está creada por la liminalidad de lo tangible/intangible. Mark Richard Couture ha demostrado el uso de cierta "liquid undulation" en el poema "Ah, que tú escapes". En él, lo liminal se da por descripciones "full of liquid and gaseuos descriptive terms" ("El agua" 22).

Lezama acerca la lupa al fenómeno natural y lo expande a ciclo universal. Obsérvese que las descripciones ocurren en lo liminal, en el borde, en esa frontera donde se da el caos, donde ocurre el fenómeno fractal como patrón repetible. Hago primero un inventario semántico de diminutivos y luego de situaciones "bordes". Los diminutivos que denotan microespacialidad son: yerba, pequeño, oreja, hoja, trotico, aleve, lluvia. En favor de esta minimalidad ocurre también la contaminación de las imágenes, donde el caballo se empequeñece al producir un trotico o la yerba baila en su pequeño lindo frío 
desembocando (sugiriendo) en la imagen rocío. Una de las características del barroco lezamiano, que anota Mark Richard Couture en su análisis de "Ah, que tú escapes," es la "aposiopesis" "for ellipsis presupposes that what is omitted is understood" (23). En el poema "Venturas criollas" que he revisado, el concepto de rocío, es un ejemplo del uso de la aposiopesis, como recurso.

Continuando con el inventario semántico y compatible con el uso de diminutivos, ocurre la descripción de estados liminales. Los objetos que denotan liminalidad son: noche, húmeda, despierta, amanece, puerta, haciendo hablar a las yerbas. Es sobre estos conceptos liminales, fronteras que pivotean los desplazamientos lezamianos a que se refiere Bejel y comenta Mark Richard Couture en su análisis de "Ah, que tú escapes": "Bejel reads the poem as an example of what he calls 'la fuga semántica,' a technique charaterized by succesive displacements of the logical connections of language as the poem moves from one image to another" ("El agua" 23). En el inventario semántico que he ofrecido la noche amanece; la humedad se convierte en lluvia, la yerba se transforma en oreja y la hoja despierta como oreja y luego amanece como puerta que se abre al caballo. Estos desplazamientos unidos a los otros elementos barrocos mencionados conforman la compleja red de analogías a que se abre el texto lezamiano.

En la magistral y casi imperceptible conjunción de factores observados es que se logra lo que denomino el "barroco metafórico" o la "metaforización barroca" lezamiana. Estos factores son en este poema, repito, el panteísmo, la narración elíptica y la perspectiva microespacial. Respecto a la perspectiva microespacial, Sarduy aborda el tema desde un ángulo ligeramente diferente arrojando claves importantes que benefician la idea esbozada: "Está, la vida de Lezama, sellada por lo que fue también su sistema 
poético y título de su obra clave: La Fijeza. Y aún más, el encierro, una persistente inmovilidad" ("Cartas” 35). Es la fijeza y la inmovilidad, pero a su vez el ingenio y la sensibilidad del artista la que crea una obra novedosa con los ingredientes de la realidad más lata. Un balcón, un mulo, una hoja, un hueco en la mesa no son obstáculos para el vuelo fantástico lezamiano, por el contrario, son estímulos, como también vio Sarduy: "Pero como si a la fijeza física, al encierro insular y doméstico correspondiera, por una ley de identidad de antípodas, la suprema agilidad, la fulguración de las asociaciones, la cultura de Lezama lo abarca... al mismo tiempo, todo" (sic) (Cartas 36).

La perspectiva microespacial en Lezama toma diferentes formas según el género del texto. Reviso ahora un ejemplo de esta perspectiva que es motivo recurrente en la novela Oppiano Licario, en las páginas 133 y 157. Este ejemplo es fundamental para entender la síntesis que opera el lenguaje lezamiano en ese vínculo esencial entre metaforización barroca y sensualismo criollo. En esta escena Palmiro escapa de unos guardias rurales que logran matar a su hermano: "Palmiro vio toda la cerrazón del bosque en su súbito y como un fanal o centella que venía sobre su frente. Saltó, trepó y resbaló dejándose caer. Su segundo salto, nunca supo cómo se le había abierto aquella salvación, fue dentro de la oquedad donde las abejas elaboran la llamada miel de palma" (Oppiano 132).

La narración comienza con una intensidad de acción y unos marcadores referenciales que coinciden con cualquier descripción en una novela de acción. Pero este para nada es el caso, ni la intención de Lezama. Dentro de la oquedad, abandonada por las abejas, Palmiro encontró la salvación. Esta imagen tiende puente con el tokonoma lezamiano. Palmiro ha llegado a otro espacio, a un espacio liminal del cual saldrá 
semiconsciente por la pérdida de sangre, pero que lo marcará lo suficiente como para volver a él. El enclaustro en la imagen que analizo es salvación. Es un enclaustro necesario, pero de alguna manera acogedor. Se repite la idea del locus amoenus en ese refugio espacial. Nos muestra la capacidad de adaptación a ese entorno. Es la asunción y la asociación de la perspectiva microespacial como instinto de conservación.

Miremos a otra dimensión del asunto donde el evento descrito se correlaciona directamente con el sistema de Lezama. Las condiciones en que procede Palmiro y la simbología del evento no son gratuitas. El narrador de Oppiano Licario nos hace saber que "Palmiro vio toda la cerrazón del bosque en su súbito y como un fanal o centella que venía sobre su frente" (132). El concepto súbito ha sido explicado por Lezama en varias ocasiones y no pienso que en ésta sea gratuito. Aún más si se tiene en cuenta la semejanza de toda la escena con la lógica del concepto lezamiano. Dice Lezama:

Existe también lo que he llamado el súbito, que lo podemos considerar opuesto a la ocupatio de los estoicos. Por ejemplo [dice Lezama] si un estudioso del alemán se encuentra con la palabra vogel (pájaro) después tropieza con la palabra vogelbaum (jaula de pájaro) y se encuentra después con la palabra vogelon, de súbito, al restallar como un fósforo la causalidad pájaro y jaula para pájaro, se encuentra con el incondicionado vogelon que le entrega el significado del pájaro penetrando en la jaula, o sea la cópula. (Álvarez, Orbita 24)

Palmiro entra al bosque quizás describiendo el ejemplo de vogelon o pájaro entrando en la jaula. Pero la escena juega con la imagen de cópula y con el concepto súbito, en más 
de un sentido. El vocablo súbito, la alusión fálica de las palabras fanal y centella y seguidamente la introducción de Palmiro en la palma completan la idea.

Aparentemente la descripción y la intensión van por lados diferentes. He expresado que la escritura de Lezama es una justificación para su propuesta estética. Éste es un ejemplo de cómo el barroco, o en este caso la alegoría, avanza paralela a la descripción vernácula del texto. El texto se densifica porque existe un substrato sistémico al cual responde y es aquí donde está la conexión entre perspectiva microespacial y barroco metafórico. Los múltiples significados de las palabras y de las frases presentan un texto polífono simultáneamente. Esto establece una diferencia con el barroco por yuxtaposición borgeano. El estilo lezamiano acumula plexos de significados que dan profundidad o relieve a cada fragmento de texto. El tejido no crece solamente en la dirección del discurso o, ni siquiera, en el plano. Crece también, y fundamentalmente en profundidad; y a esto he denominado plasma literario.

Antes de continuar con la evolución de la imagen de Palmiro, hagamos un deslinde en el recurso alegórico mencionado. Según Teuber: "Se le ha denominado al sistema poético de Lezama barroquismo, pero las raíces de su estilo se remontan ciertamente a un pasado mucho más lejano en la historia de las ideas. La poética de Lezama está basada en la figura retórica de la alegoría, la cual, según la define Quintiliano, 'demuestra lo uno en las palabras y lo otro en el sentido"” (Teuber 7) ${ }^{25}$. La tendencia en muchos análisis es llamar simplemente barroco a todo lo complejo, y ésta no es mi intención. En mi opinión, lo que sucede, a la vez que estoy de acuerdo con lo expuesto por el Teuber, es que Lezama combina las estructuras alegóricas y simbólicas del texto con otros muchos recursos barrocos, entregando una suerte de "pastiche de 
estilos", si se quiere, que pertenece al postmodernismo y hace del estilo de Lezama un neobarroco en lugar de un barroco.

Al establecer las diferencias entre la alegoría barroca y la alegoría lezamiana, Teuber agrega: "En Lezama la alegoría visible se revela así como suplemento de una ausencia invisible, que nunca será alcanzada y que sólo por ser inalcanzable obsequia un espacio a lo visible" (8). Aquí nos acercamos a esa conexión mítica a la cual el escritor dirige sus glóbulos de imágenes. Esa "ausencia invisible" que nunca será alcanzada se conecta con el panteísmo lezamiano que trata de indagar la realidad y a fuer de no encontrar respuesta, la reduce a su sistema poético y la vuelve autorreferencial. A su vez, este sistema poético se tiene que complejizar para competir con esa realidad, para que la suplantación sea total (verosímil, en otro nivel). Aquí también se acercan las poéticas de Borges y Lezama. Por diferentes caminos se llega al mismo punto.

Concluyo con la imagen de Palmiro en Oppiano Licario. La utilidad de esta segunda fase de la imagen es que la oquedad de la palma sigue creciendo como recinto acogedor y ratificando la idea de esa perspectiva enclaustral y mínima donde se da la poesía. Pero, además, ahora se convierte en vía onírica. Los guardias en retirada hieren a Palmiro dentro de la palma a quien "el espanto le secuestró el grito, pero tuvo que caerse aún más en la oquedad dejada por las abejas" (133). Esta imagen tiende un puente con la fuga del yo poético hacia el tokonoma en "El pabellón del vacío" y con "VI" (Poesía 365), para luego concluir con la madrugada en que rescatan a Palmiro "durmiendo el sueño de la pérdida de sangre" (365).

Hemos visto la microespacialidad de Lezama en su dimensión metafísica, en su dimensión telúrica y por último en su dimensión onírica. Esta microespacialidad define la 
característica principal del estilo lezamiano dado por la fragmentación, el minimalismo y una visión que focaliza el elemento constitutivo del todo. Este estilo es, sin duda, compatible con el panteísmo lezamiano. Lezama observa el detalle, los bordes de los fenómenos porque en ellos cree encontrar la explicación y fuente del conocimiento a escala mayor.

Este estilo que focaliza lo fragmentado, la porción, lo mínimo de los objetos y fenómenos, polariza las estéticas de Lezama y de borges. Según la perspectiva borgeana, el universo es espacial, mensurable, simétrico, euclidiano. Sin embargo, desde el punto de vista lezamiano, el universo es minúsculo, abigarrado, fractal, cóncavo. De alguna manera ambos convergen en los patrones que lo arman. El espacio-el laberinto-la oquedad es el camino arquetípico que sigue la metáfora; es el derrotero intelectivo que conecta a ambos mundos. El patrón común es la palabra que se abigarra o se expande, se retuerce o se curva, para replicar esos pliegues espaciales o esas circunvoluciones cerebrales que tejen las realidades externas e internas. 
3. - Ficción de racionalidad: la memoria como operador mítico

Este capítulo condensa las dos poéticas en el uso de la memoria como el operador que elabora el mito en el instante de la enunciación. En los escritores que analizamos, existe un afán y una metodología de la mitificación. Para ellos el mito no es algo que se construye socialmente por una comunidad de hablantes, a medida que éste es enunciado a través del tiempo. El mito es aquí, más bien, la categoría a que se eleva una escritura, que proviene del uso de la cultura o la escritura misma, como componente constitutivo, y que está destinado a ir de vuelta a esa cultura. Borges y Lezama escriben con toda consciencia de trascendencia y su lector implícito es la cultura.

Este proceso de mitificación, o de "añejamiento verbal" ocurre a nivel de la memoria. Se entrega un producto fundido con asentamientos verbales y metafóricos establecidos, y descontextualizados, a su vez, de un referente específico. Los intensos estudios que ambos escritores realizaron sobre la metaforización y sus primeras experimentaciones barrocas, les otorgaron la capacidad de entender las formas de cristalizar, en estructuras de mito, cualquier fragmento de texto. Al decir de Saúl Yurkievich: "Desde temprano, a partir de su adhesión al ultraísmo, Borges comienza a interesarse en la metáfora, en su empleo y en el análisis de su funcionamiento. [. . .] Borges es el primer hispanoparlante que indaga, con criterio moderno, en los mecanismos constitutivos del enunciado metafórico, en sus efectos lógicos y en su valor gnómico" (La movediza modernidad 107).

Las condensaciones de Borges y Lezama son el rezumado de toda la cultura universal. Éstas son pasadas por el tamiz de sus sensibilidades y vueltas a poner en términos seudoclásicos, que se alejan del uso común en cuanto a elección léxica, y se 
alejan del localismo en cuanto a referente. Como señala Alina Camacho-Gingerich, citando, a la vez, el ensayo de Lezama "Mito y cansancio clásico": "Todo, según Lezama, tiene que ser reconstruido o inventado de nuevo: '[ . . ] los viejos mitos, al reaparecer de nuevo, nos ofrecerán sus conjuros y sus enigmas con un rostro desconocido. La ficción de los mitos son nuevos mitos, con nuevos cansancios y terrores"” (Camacho-Gingerich 7; Lezama, La expresión 20).

Esta concepción lezamiana, de la reaparición (y utilidad) de los viejos mitos con "rostro desconocido," es absolutamente afín a la idea de Borges sobre la iteratividad en la literatura y la importancia de la recepción de un texto. En dicha idea se basan los asuntos de los relatos "El brujo postergado" y "Pierre Menard autor del Quijote," por mencionar sólo dos. La memoria es el factor decisivo en este proceso. Los generadores de mitos preservan la memoria metafórica de la lengua, parecen decirnos Borges y Lezama. Por esta razón, al entregar los viejos mitos revestidos de nuevo ropaje, a una época que los ha olvidado, o no los conoce, se crean nuevos productos estéticos. Esta idea la conceptualiza Lezama en la imagen, como nos explica Alina Camacho-Gingerich: "La imagen, [ . . ] no es sólo un recuerdo o reminiscencia que, al ocupar un vacío, adquiere vida independiente. La imagen convierte lo lejano en cercano, el pasado en el presente, la ausencia en presencia" (113).

Estamos ante la teoría de la mitificación, donde la imagen, o ese cristal de lenguaje trabado en metáfora, en brusca condensación de significados y sugerencias, convierte "el pasado en presente" y el presente (la actualidad) en pasado, mitificándolo. Por eso es que la poesía para Lezama, nos dice la crítica: “[ . . . intenta rescatar la unidad y visión fabulosa, maravillosa, de los tiempos primigenios" (127). Este mismo 
mecanismo mitificante garantiza la permanencia de los cuentos de Borges en la memoria de su lector, conjuntamente con el carácter metafictivo y de "pastiche" de estos textos, elementos éstos, conformadores del mito. Según Northop Frye: "Literature continues in society the tradition of myth-making, and myth-making has a quality that Lévi-Strauss calls bricollage, a putting together of bits and pieces out of whatever comes to hand" (The Great Code xxi).

No todos los escritores participan igualmente de ese proceso de construcción de mitos, o de recreación de viejos mitos. Las características peculiares de Borges y Lezama son que lograron acumular una memoria cultural impresionante, que les permite un gran espectro de posibilidades mitificadoras; por un lado, y por otro, que sus mitos son elaborados con la materia prima de otros mitos. Estos autores trabajan en las estructuras con las que la lengua construye sus propios mitos. A eso me he referido como poética teórica. José Miguel Oviedo ha indagado en esta capacidad de los textos de Borges de permanecer en la memoria de sus lectores, a partir de sus amalgamamientos con la cultura total: "They are versatile and porous texts, [. . .] This singular quality of Borgesian texts is certainly asociated with their brevity and the cumulative effect that they have on the memory of the reader" (129).

La porosidad de la que habla el crítico permite una modestia textual donde la cultura entra y sale. Ésta es percibida como partícipe del texto sin tensión. Borges convierte sus textos en arquetipos. Cada macroenunciado del cuento tiende tentáculos que se afirman en varias "eras imaginarias" a la vez. Los textos están en un constante diálogo epistemológico con otros textos. Es decir, generalmente, los textos con los que se establece la asociación son textos epistemológicos, o que indagan en el origen del arte, la 
cultura y la realidad. La creación del grupo Orígenes, en Lezama, y el inicio ultraísta de Borges, se pudieran ver aquí como la reafirmación de esa indagación teórica metaestética.

Ese trabajo de convertir textos en arquetipos está asociado a los procesos de memoria, desde donde proceden las condensaciones imaginales y hacia donde se dirigen. De manera que existen varios factores en el mencionado proceso de mitificación. He mencionado la memoria como ese depositorio donde se mezcla el viejo mito con el mito revestido. En este sentido, la escritura de los autores que revisa este estudio, juega con la imagen de la memoria explícita e implícitamente. Tal es la función de los epítetos "memorioso," "imaginarias," "dador" y de los conceptos "laberinto," "biblioteca ciega," "curso délfico" y "vasos órficos," en la semántica de los autores que investigo. Estas construcciones pretenden ilustrar, de alguna manera, las sinuosidades mentales, los sistemas comunicantes con que opera nuestra propia máquina. A nivel del receptor, he denominado ficción de racionalidad, al concepto que recoge este proceso, pues la racionalidad, desde la que se entrega esta memoria como supuesta verosimilitud, es fictiva, creada para el propósito hedónico y verosímil que soporta.

La ficción de racionalidad responde a una postura intencional que manifiestan los autores frente al texto y al lector implícito. La ficción de racionalidad es el recurso del cual se valen los narradores de los textos respectivos, para crear el mito a partir de una supuesta verosimilitud, donde la historia, la filosofía, la religión, la ciencia y la cultura entran en la escena literaria, como en un pastiche, formando un todo indisoluble e indiferenciable. La instancia de pertenencia de la ficción de racionalidad es el postmodernismo. Aunque existen recursos semejantes en toda literatura y en todos los 
tiempos, nunca se ha dado tal recurso a niveles tan profundos de la semiótica social y con tal grado de irreverencia respecto a las instituciones con las que juega. Pero el rasgo verdaderamente tipificador de la escritura de los autores que trato es, más que la metaficción, la meta-mitificación.

Debo diferenciar brevemente una tendencia común del "boom" latinoamericano, con respecto a los autores que me ocupan. Santiago Juan-Navarro, revisando algunas características de la "ambigua postmodernidad" en las novelas de Carlos Fuentes, observa los siguientes elementos: "El pastiche de crónicas, teorías historiográficas y versiones apócrifas y fantásticas de la historia tiene como función cuestionar y desplazar las versiones recibidas del pasado. La reescritura del mito y la historia dentro del marco de la novela permite a los grupos ex-céntricos su inscripción en el registro histórico [. . .]." ("Entre el revisionismo" 184).

Primeramente, importa aclarar que Borges y Lezama utilizan estas características con ciertos intereses propios. El enfoque de Carlos Fuentes va dirigido hacia lo que Northop Frye denomina "history as a primary verbal imitation of action" (The Great Code 65), mientras que la mitificación de Borges y Lezama va dirigida, en parte, a lo que el crítico canadiense denomina como: "poetry as a secondary verbal imitation of thought: expreses the universal forms of thought and is not subject to 'truth."' Los escritores de este estudio enfocan sus estéticas a la creación de sistemas de pensamientos, a través de recursos poéticos. Más que interesarse por la Historia como praxis, se interesan por los mecanismos que diferencian o unifican la historia y la ficción. Si el propósito intelectual de Carlos Fuentes es el revisionismo histórico; el de Borges y Lezama es un revisionismo ontológico y teleológico. Va igualmente enfocado a un proceso de deconstrucción y re- 
asimilación, pero aquí interesan la rescritura de la poética, las concepciones estéticas acerca de la novedad metafórica, y cómo estos procesos se relacionan con la realidad.

En este sentido, aunque Borges se considera un precursor de "boom" y Lezama un integrante del "boom" II, según la periodización de Donald L. Shaw en su Nueva narrativa hispanoamericana, opino que las indagaciones de Borges y Lezama escapan a tal taxonomía. Las obras de estos autores que me ocupan, siguen siendo eternas precursoras de otras muchas nuevas corrientes e interpretaciones, y lo son, en parte, por la jerarquización del componente hedónico de la literatura y por recuperar una sed de poesía en la "humanidad" moderna. A esto se puede agregar la falta de referencialidad específica y de compromiso extra-literario, como tendencia primaria de sus estéticas. Borges y Lezama le devuelven a la literatura su estatus de realidad idealizada. Nos devuelven el mito de la residencia en un mundo épico-textual.

En cuanto al elemento de marginalidad expresado en la cita de Juan-Navarro (184), los autores en cuestión se inscriben en la marginalidad continental latinoamericana. La operación de revisión cultural, estética y filosófica que tanto Borges como Lezama llevan a cabo, los pone en la competencia universal de las artes, y los saca de la marginalidad. Los inscribe "en el registro histórico del que tradicionalmente habían sido excluidos" (184). Posteriormente a esta inscripción, viene la erección de estas visiones como cánones de poética moderna, proceso que está teniendo lugar en el presente, con la intertextualidad de ambos autores en el neobarroco y en la alteridad de los postmodernos.

Respecto al enfoque de Borges y Lezama que he asociado a la tipología de Northrop Frye "poetry as a secondary verbal imitation of thought [...] and is not subject 
to truth," debo aclarar, que si bien la estética de estos autores pretende una verosimilitud, a través de la ficción de racionalidad, que se define por esa "verbal imitation of thought," existe un componente de esa imitación que sí presupone una verdad (The Great Code 65). En el mundo moderno institucionalizado, que registra los productos estéticos como propiedad privada de un autor, las metaficciones e intertextulidades de Borges y Lezama devienen irreverencia e invectiva a la etiqueta de los derechos de autor y a la autoridad de las fuentes.

En ese sentido, además de revisionismo, estamos en frente de una deconstrucción de la cultura actual donde estos autores anotan una contradicción insoluble. Por un lado, se demuestra que los textos actuales participan de una hibridación intertextual imposible de evitar, y donde no se reconocen fronteras de novedad; y por otro, cada vez el mercado hace más estrechos los límites de la propiedad intelectual. Borges y Lezama muestran este oximoron de la cultura moderna implícitamente en sus propuestas estéticas, y atacan la falsa relación causal a nivel de instituciones humanas.

En este caso, las poéticas en cuestión, conllevan un sentido filosófico más profundo, por cuanto el uso de las instituciones mencionadas forma parte estructural de la creación, y el texto, como tal, se cuestiona, desde sus propias raíces, las sempiternas verdades sobre la historia, la existencia de Dios, la propia literatura, las ciencias y las instituciones que catalogan el producto de sus creaciones. En otras palabras, estos autores se cuestionan las bases de la cultura y por eso sus literaturas apuntan a la creación de nuevos valores y asentamientos mitológicos. Las obras de Borges y Lezama deben enmarcarse en esa etapa de deconstrucción de la cultura moderna y del logocentrismo que, a su vez, para deconstruirse a sí misma usa y "ab-usa” de esa misma cultura a la que 
parodia. Y esto, de nuevo, los desenmarca y los proyecta a corrientes de pensamientos futuras.

Lo que ha dicho David Huerta de Lezama puede afirmarse igualmente de Borges. De hecho, el nombre de Borges aparece a continuación de la cita en similar valoración. Plantea el crítico sobre Lezama: "Después de Lezama, las cosas ya no podrán ser iguales en el contexto de la literatura de lengua española. No puso 'las cosas en su sitio': las sacó del sitio en el que estaban, [. . .] y creó nuevos espacios para que leyéramos, escribiéramos, entendiéramos, imagináramos" (27). Se han expresado opiniones semejantes sobre estas características de la escritura de Borges y de Lezama, todas apuntando a su capacidad de reminiscencia, a su potencia de cambio y a su naturaleza mítica. Ahora, me ocuparé de buscar las causas del pensamiento mítico, de explicar la ficción de racionalidad y la memoria como operador fictivo, dentro de los texto propiamente.

Borges concluye "El sueño de Coleridge" con una observación acerca de los arquetipos: "Ya escrito lo anterior, entreveo o creo entrever otra explicación. Acaso un arquetipo no revelado aún a los hombres, un objeto eterno [. . .] esté ingresando paulatinamente en el mundo; su primera manifestación fue el palacio; la segunda el poema. Quien los hubiera comparado habría visto que eran esencialmente iguales (Obras completas 2:23). Con este relato Borges construye, ni más ni menos, la tercera manifestación de ese arquetipo que está ingresando en el mundo. Borges lo ha observado y lo recrea como forma de garantizar su ficción. El mito de Borges aquí, consiste en crear el mito de que los mitos se repiten por causa de tal arquetipo. 
Borges se ha introducido en la creación de Samuel Taylor Coleridge y ha reelaborado sus ideas utilizando una racionalidad ficticia. Ésta nos hace ver el relato de Borges como la explicación de los dos símbolos anteriores y no como una ficción en sí misma. Borges utiliza el dato histórico, las citas literarias, los nombres de escritores o personajes de la historia como elementos retóricos de esa ficción de racionalidad. Según el narrador de "El sueño de Coleridge," tanto el palacio como el poema son idénticamente iguales, y el arquetipo de ambos es anterior a la realización de la obra. El palacio es primero soñado por el emperador mogol (Obras completas $2: 21)$ y el sueño de Coleridge es anterior a Coleridge en muchos siglos (a no ser por un "si" condicional). El arquetipo del palacio parece recorrer la historia de las manifestaciones artísticas; pero su origen onírico lo hace efímero e improbable. De esta manera, Borges nos entrega la clave, conjuntamente con el obstáculo para llegar a ella.

La idea de la memoria subliminal de la humanidad, término muy parecido a esa memoria genética de la que se habla hoy con certeza, está planteada en este relato como misterio futuro dado por ese "acaso". La imagen del río que fluye (leitmotif central de "El inmortal" y otros relatos) subyace en el inconsciente del texto, en su implicitez. Levita como una tangibilidad concomitante que refuerza o ejemplifica el decursar de esa memoria. Borges tiene las dos ideas en mente en su relato, la del arquetipo, como el objeto oculto que el poeta nos entrega muy sutilmente, y la del río, como una fuerte imagen de la realidad asociada en la cultura al proceso del tiempo y del cambio. El río es un trasfondo de verdad que garantiza, por comparación alegórica, la verosimilitud del arquetipo. 
El motivo de la corriente subterránea garantiza, en mi opinión, el fluir del relato. Existe aquí un juego cruzado donde el arquetipo invisible se menciona explícitamente y el río, conocido por todos, se redibuja en la narración, a la vez que se regatea su imagen. "El sueño de Coleridge" está presente en el poema Kubla Khan: "Where Alph, the sacred river, ran/ Through caverns measureless to man" (Coleridge 252). El arquetipo que Borges propone está siempre asociado con un decursar imperceptible dado en la metáfora del río subterráneo. El poema porta la idea de cierta repetibilidad arquetípica en la frase "caverns measureless to man", pero la carga metafísica en el relato Borgeano es sumamente mayor. También su demostración retórica es un recurso novedoso por su forma de interacción con el receptor.

Estos elementos construyen el mito borgeano. La memoria garantiza la preservación de la cultura. Es una memoria tangible e intangible, comprobable e incomprobable, dada por el arquetipo y por los resultados de las obras. Pero el río subterráneo, o el arquetipo mismo, también comportan una memoria que puede o no coincidir con la de la humanidad consciente. En este borde se da el escepticismo de este relato. El proceso de escritura de Samuel Taylor Coleridge, se nos presenta como el proceso de escritura de Borges. El narrador del relato que analizo nos cuenta cómo el poeta recordaba los aproximadamente trescientos versos, que había soñado sobre el palacio: "Los recordaba con singular claridad y pudo transcribir el fragmento que perdura en sus obras" (Obras completas 2:20).

El poema se genera desde una semilla imaginal: "el texto casualmente leído procedió a germinar y a multiplicarse" (20). Borges nos explica algo que ha rescatado de los archivos de la historia. Pues la ficción del sueño pertenece a Samuel Taylor 
Coleridge, así como la versión sobre su indisposición y el consumo de "an anodyne" (Allison 252). Borges se introduce en ese intersticio ficticio y explota un relato que se abre geométricamente, multiplicando la ambigüedad del propio registro histórico-fictivo de Samuel Taylor Coleridge. La precisión con que Borges enumera los datos que rodean la confección del poema juegan como pivote entre la realidad y la ficción. Recordemos que el poema de Samuel Taylor Coleridge ya es realidad de la historia literaria y su ficción es un dato histórico también.

En el relato "Pierre Menard, autor del Quijote," el autor recrea la obra con procedimientos semejantes. Pierre Menard crea la "inconclusa" obra (Obras completas 1:446), a partir no de una copia, ni de componer otro Quijote mecánicamente, sino de la creación de la obra página por página, y asegura que su empeño es "el término final de una demostración teológica o metafísica" (446) donde el "mundo externo, Dios, la casualidad, las formas universales- no es menos anterior y común que mi divulgada novela" (446-47). En ambos casos el proceso de escritura parece atribuirse a una memoria arquetípica que garantiza la repetición estética. Por eso, Borges ha afirmado anteriormente que las verdaderas metáforas, "las que formulan íntimas conexiones entre una imagen y otra, han existido siempre [. . .]." (Obras completas 2:48).

La memoria es una imagen recursiva en Borges. Hemos visto como "El sueño de Coleridge" juega con ese elemento que preserva la totalidad de la creación humana, ya sea de ficción o no. Sus mitos se arman supuestamente desde códigos nemónicos. Pero la memoria procede en la demostración del texto y apoya la lógica discursiva a nivel del narrador. Es decir, la memoria es el mecanismo mediante el cual se agrupa la narración en una pieza. Es la memoria la que permite el acceso del narrador al archivo mitológico- 
cutural. Sin embargo, intradiegéticamente, la memoria es una entidad falible que no significa "verdad". De manera que, a la vez que la memoria es el operador mítico, la racionalidad es fictiva, puesto que se asienta en falsos presupuestos.

La prolongada perspectiva del cúmulo y el hábito del hallazgo racional donde se constata lo universal de la imaginación conllevan al pensamiento sistémico. Borges muestra estas características en su escritura. El descubrimiento de las leyes que ordenandesordenan el universo y el de las que estructuran la mente como reflejo de éste, capaz de reproducir sus laberínticas combinaciones conducen, ineluctablemente, a la síntesis, a la catalogación. Ésta es la idea que reside detrás de los arquetipos. Existe en Borges una especie de proyección sicológica, que lo hace plasmar como ficción lo que constata como erudito. El arquetipo es una cristalización de asociaciones que permite almacenar eficientemente el conocimiento en las estructuras mentales. Los arquetipos son un sistema de catalogación, a la vez que las leyes de formación de los algoritmos míticos. Un arquetipo simplifica, estandariza lo esencial del algoritmo "creante" y establece su ley de continuidad. De ahí que el arquetipo se comporte como el conducto del mito.

Según Northrop Frye el mito, desde el punto de vista de la crítica literaria, significa "mythos, plot, narrative, or in general the sequential ordering of words" (Anatomy of Criticism 31). En este estudio que considera la memoria como operador fictivo, nos interesa enfocar la conexión entre el mito y la memoria. El mito, es aquí, efectivamente, una secuencia narrativa; pero es también un cuantum metafórico, un "mitoma" que garantiza su permanencia en la cultura por su fuerte vínculo entre realidad e imaginación. Cuando Borges asocia la imagen del río a un relato, está inscribiendo dicho relato dentro del mito temporal que implica la imagen de río. El narrador del texto 
borgeano nos hace confluir con su relato a ese río arquetípico que ya es parte de un mito universal y que reúne a todos los ríos posibles, ya sea el heraclitano, el del Eclesiastés, el de La divina comedia o cualquier otro río arquetipal.

La conexión entre el mito y el arquetipo es que, según Borges, el mito no es arbitrario, como tampoco lo es el signo lingüístico. ${ }^{26}$ Uso el ejemplo del signo lingüístico para visualizar mi concepción sobre el mito y porque creo firmemente en la sistematicidad del lenguaje. Un signo no puede ser arbitrario (relativo) y convencional a la vez. La convención ha desterrado para siempre la arbitrariedad. Algo semejante ocurre con el mito. Su origen pudiera ser arbitrario, esto es discutible y depende de sus arquetipos generadores; pero ahora el mito es convencional, tiene existencia definida en la memoria cultural de la humanidad, por tanto no es arbitrario. Cuando Borges dice que no existen metáforas absolutamente novedosas (Obras completas 2:48), se está refiriendo precisamente a esta fijación metafórica en la memoria colectiva, y su conocimiento de esta memoria colectiva lo ha llevado a una efectividad narrativa, que se comunica con esa memoria.

Es decir, el arquetipo es algo anterior al mito y establece una relación bastante directa entre la realidad y nuestra percepción. Según Northrop Frye: “[ . . .] the real interest of myth is to draw a circunference around a human community, and look inward toward that community, not to inquire into the operation of nature" (The Great Code 37). Posteriormente el crítico canadiense ejemplifica: "Star myths are a good example of the creative autonomy of myth [. . .]." (37). Sin embargo, uno de los elementos de ficción de Borges es, precisamente, el vínculo de los mitos con la indagación epistemológica y ontológica, además de incluir en su metamorfosis literaria a la historia de la ficción como 
tal. Existe en estos textos un fuerte componente metafísico, donde una especie de arquetipo conecta el universo real con el universo mental. Este elemento es sumamente sugerente y da a los textos de Borges vitalidad y contemporaneidad. La presencia del arquetipo y su demostración, a través de mitos literarios, es parte de la ficción de racionalidad que estudio.

He aquí algunos ejemplo de arquetipos que aparecen en La cifra. En el poema "Las dos catedrales" de este libro tenemos: "Son copias temporales y mortales/ de un arquetipo inconcebible" (21-22) (Obras completas 3:294); en el poema "Beppo" tenemos el arquetipo mistificando la cultura al presentar a Plotino como sombra: "Son simulacros que concede al tiempo/ un arquetipo eterno. Así lo afirma,/ sombra también, Plotino en las Ennéadas." (11-12) (295); en el poema "Blake" del mismo libro, se responde a la pregunta “¿Dónde estará la rosa que en tu mano/ prodiga, sin saberlo, íntimos dones” (12), con los siguientes versos: "O [puede ser] un terrible arquetipo que no tiene/ la forma de la rosa." (13-14) (308); unas páginas adelante en "Nihon” dice: “desde tigres pintados por quienes nunca vieron un tigre y nos dan casi el arquetipo" (336).

El poema "Correr o ser" vuelve a utilizar el río como símbolo del decursar. Este recurso remite a toda una alegoría cultural que va desde Heráclito, y los textos bíblicos, pasando por el tomismo y el escolasticismo, hasta llegar a la cultura moderna: “Fluye en el cielo el Rhin? ¿Hay una forma/ universal del Rhin, un arquetipo,/ que invulnerable en ese otro Rhin, el tiempo,/ dura y perdura en un eterno ahora" (1-4) (322). En el poema "Blake," se alude indirectamente al nominalismo, en este poema, Borges establece una especie de panteísmo donde el Rhin está en el cielo o es "ese otro Rhin, el tiempo." Borges establece un esquema que va más o menos así: el arquetipo nos sugiere la 
imaginación; pero el arquetipo procede de la misma fuente que informa el universo. Luego entonces tenemos una especie de consciencia universal ordenando la realidad, que genera arquetipos y nos los sugiere.

La Poética de Borges se presenta opuesta a la idea de Northrop Frye sobre la relación de los mitos con la realidad. En el caso de Borges, el mito está asociado a la realidad (fictivamente), a través de los arquetipos. Éste es indiscutiblemente un recurso fictivo de Borges. En el esquema de Northrop Frye donde la poesía se define como "a secondary verbal imitation of thought [. . ] not subject to "truth" y la filosofía como "a primary verbal imitation of thought [. . .] subject to criteria of logic" (The Great Code 65), debemos situar a los textos de Borges en un punto límite entre el primero y el segundo. Borges incluye en su ficción las corrientes de pensamiento y filosóficas que hemos heredado del racionalismo positivista $\mathrm{y}$ tenemos como verdades. Su ficción cuestiona las bases de la filosofía, la religión y la moral en las cuales se asienta la cultura, por eso la ficción de racionalidad es revisionista y postmoderna.

No pretendo minimizar, ni la inmensa capacidad organizativa que estructura la obra de Northrop Frye, ni su precisión respecto a la crítica arquetípica o a la relación de los mitos con los géneros literarios delimitada y expandida en Anatomy of Criticism. Mi interés es observar cómo la evolución de los arquetipos sigue rumbos diferentes y complementarios, después de los aportes de Carl Gustav Jung. El sicólogo suizo vincula los arquetipos a la poesía en su ensayo "On the Relation of Analytical Psychology to poetry," publicado en 1923 (Jung 656). Pero indiscutiblemente las obras de Borges y Northrop Frye avanzan un gran trecho en este terreno. Éstos últimos relacionan directamente el arquetipo con ciertos motivos y temas literarios. Además, El extenso uso 
que Borges da a los arquetipos, y la carga metafísica que este elemento suma a sus ficciones, es, sin duda, una creación efectiva y actualizada. Este elemento cobra interés mayor, cuando se comparan las fechas en que ambos procesos tienen lugar: el teórico, llevado a cabo por Northrop Frye, y el literario, desarrollado por Borges.

La teorización de Northrop Frye sobre los arquetipos en general se encuentra recreada por Borges, de manera práctica, en sus ficciones. Ambos desarrollaron estas ideas en las décadas de los 40s y 50s. En este sentido, creo que es válido decir que Borges comparte con el crítico canadiense la siguiente idea: "The archetypal view of literature shows us literature as a total form and literary experience as a part of the continuum of life, in which one of the poet's functions is to visualize the goals of human work" (Anatomy of Criticism 115). El sentido teleológico de esta frase es igualmente compartido por Lezama.

Un estudio que vincule más consistentemente las divisiones genéricas y arquetípicas propuestas por el crítico canadiense y los símbolos y géneros literarios en Borges, estaría por hacerse, y tendría sentido dado las muchas coincidencias al respecto. La imágenes de jardines, en Borges, podrían ser asociadas al "vegetable world" de Northrop Frye (Anatomy of Critcism 149); así como los laberintos al "inorganic world" (150). Un especial desarrollo de este tema, se puede ver en el arquetipo denominado por el crítico "The archetype of geometrical images" (Fables of Identity 20). Según esta definición: "In the comic vision the mineral world is a city, or one building or temple, or one stone [...]" (20).

Este último arquetipo se puede hallar en muchos símbolos de Borges como las bibliotecas, las espirales, los prismas y los espejos. Catharine E. Wall, en su artículo 
"Word and Image in the Hispanic Avant-Garde," desarrolla un estudio donde relaciona el ultraísmo de Borges con la figura del prisma y con una estética de ésta. Como dice la autora: "Borges was both creator and critic. His poem "Prismas" exists as an illustration of the ultraísta theoretical principles concerning the prism aesthetic" (45). El artículo muestra la compatibilidad entre el contenido del poema "Prismas," su forma o estructura externa y la estética del prima ultraísta. Esto nos demuestra una vez más que la obra de Borges es sistémica y que la parte representa al todo.

La geometricalidad en la estética borgeana guarda relación con una concepción clásica del universo. Borges trata de aprehender el espacio mediante construcciones geométricas. Es el prisma, precisamente, la figura que más refleja el escepticismo borgeano. Según Wall: "The ultraísta interpretation of the behavior of a prism results in a refraction of images that appear to be unrelated. The absence of punctuation and the simplification of syntax and structure in "Prismas" [. . .] create a flow of disjointed images that simulates cubist painting" (51). El prisma puede consirerarse un símbolo de la dispersión, como el momento en que las diferentes realidades (tiempos) de "El jardín de senderos que se bifurcan" se abren al infinito (Obras completas 1:479). Esta dispersión, a su vez, es un símbolo del escepticismo.

El estilo y la estructura del poema analizado por Wall, nos demuestran que la estética del "prisma," es parte de una cosmovisión de carácter sistémico. Esta estética se refleja a nivel textual, depositándose en recursos que denotan desconexión, yuxtaposición, dispersión, reflejando una especie de "escepticismo epistemológico discursivo," donde el estilo interno del texto, refleja la concepción externa del sistema de pensamiento que lo soporta. Al panteísmo Lezamiano, asociado con la imagen de la lupa 
en este estudio, se opone el prisma borgeano. De esta manera, se puede ver una compatibilidad entre el panteísmo lezamiano y la lupa que concentra la luz, a la vez que descubre conexiones insólitas de la materia, y por otro lado, el prisma borgiano, explicando gráficamente el proceso de desarticulación universal, que lleva al escepticismo epistemológico; a la pérdida irrecuperable de vínculo entre los rayos dispersos.

El arquetipo de "imágenes geométricas" permite asociar las construcciones de los dos palacios aludidos en "El sueño de Coleridge," a saber, el del poema de Samuel Taylor Coleridge y el de piedra, creado por el emperador mogol (2:21). El arquetipo también incluye al propio relato de Borges. Como si las pirámides aztecas y las egipcias, fueran sugeridas por la misma ley universal, quizás gravitatoria, obligándonos al mismo tipo de geometría de base ancha. Cuando Borges dice en la "Muralla y los libros," relato introducción que sirve de proemio a Otras inquisiciones: "La música, los estados de felicidad, la mitología, las caras trabajadas por el tiempo, ciertos crepúsculos y ciertos lugares, quieren decirnos algo" (Obras completas 2:13). Borges relaciona ciertos motivos de la naturaleza con estados de ánimo, con modos literarios. Esto también se pudiera ver en relación a los géneros propuestos por Northrop Frye. En este último caso, Borges rompe el esquema genérico del crítico y la relación adquiere otra dinámica.

En "Pierre Menard, autor del Quijote" también está planteado el arquetipo y es precisamente éste el que permite a su autor "recrear" la obra de Cervantes, no copiarla, no aprendérsela de memoria; sino reproducirla a partir de penetrar en dicho arquetipo. Borges recalca que existe una obra visible y otra subterránea "interminablemente heróica", "impar" y más adelante nos cita una carta de Menard: “Mi propósito es 
meramente asombroso' [ . . . 'el término final de una demostración teológica o metafísica -el mundo externo, Dios, la casualidad, las formas universales- no es menos anterior y común que mi divulgada novela"” (1:446).

En esas formas universales Borges cree ver la piedra filosofal de la literatura. Por esta razón, la novela de Pierre Menard, es tan anterior como una demostración metafísica, porque no se puede ubicar en el tiempo entendido como decursar de la cultura; sino como universal invariable, repetible, que transcurre paralelo al devenir humano. Escapa al tiempo y se asienta en las causas de armonía, entorno, simetría que sugiere Northrop Frye en su división arquetípica (Anatomy of Criticism 131-223). De hecho, el afán de recrear tópicos nórdicos, árabes, chinos o de culturas antiguas, en los textos de Borges y Lezama, es un ejemplo del uso de la memoria como operador mítico. Como nos asegura el crítico canadiense "Archaism is a regular feature of all social uses of archetypes" (108), elemento que los autres en cuestión, supieron aprovechar con efectividad.

En ambas estructuraciones discursivas, la fictiva de Borges, y la teórica de Northrop Frye, hay una visión autónoma de la literatura, donde ésta corre por sus propios cauces y escapa a periodizaciones precisas. La literatura depende de la evolución metafórica (o tropológica) y no de la evolución sociohistórica según esta perspectiva, aunque la última influya la primera indirectamente. Al respecto Frye plantea la siguiente pregunta: "And if the genre has a historical origin, why does the genre of drama emerge from medieval religion in a way so strikingly similar to the way it emerged from Greek religion centuries before [.. .]" (Fables of identity 16).

Tal parece que la respuesta está planteada en "Pierre Menard autor del Quijote" al negarse la fijeza del concepto "historia" y "verdad" asentado en el texto (género en el 
caso de Frye). Ambos conceptos varían con la evolución arquetípica de las artes y no con la evolución histórica. En el caso de Frye no es el tiempo, es la estructura mental del estadio humano, provocada por la evolución mítica, quien determina la estructura literaria (por eso se habla de antropología). Este estadio es la cristalización, en forma de canon, del arquetipo. En el caso de "Pierre Menard, autor del Quijote," el receptor evalúa, a través de su memoria cultural, o arquetípica para el caso, el valor y los códigos de la obra.

Estas últimas razones esbozadas, nos hacen pensar que la vinculación entre Northrop Frye y Borges merecen un estudio mayor. En el caso que nos ocupa, la relación se establece, a partir de buscar en Borges la capacidad de convertir los textos en mitos y de utilizar la memoria como mecanismo generador de éstos. Se puede pensar también que el desarrollo de los arquetipos en ambos autores tiene que ver con una corriente de época, con una especie de moda. En este caso estaríamos en el estadio arquetípico de la crítica literaria y de la literatura. Aún así es válida la asociación.

Como se ha venido exponiendo, Borges usa el bricollage donde toda la cultura viene a participar de su propuesta estética. Los textos establecen una asociación con la totalidad de la literatura que recrea y parodia. El uso de los arquetipos es un recurso fictivo detrás del cual se esconde una supuesta racionalidad. Los relatos de Borges se presentan de esta manera, como una ficción que descubre una verdad. La verdad es una falacia y el goce estético se logra por un efecto de ilusión. Nos vemos reflejados como historia y conocimiento en una ficción: como el mapa en el mapa, y las mil y una noches en el libro de Las Mil y Una Noches. 
La memoria también es un operador mítico en Lezama y la ficción de racionalidad ocurre en sus textos al igual que en los de Borges. La diferencia fundamental, respecto a la ficción de racionalidad, en Lezama es que éste no deconstruye explícitamente la historia y la cultura, a partir de sus marcadores externos. Lezama es menos irónico en su deconstrucción y más respetuoso respecto a las citas o a nombres propios, pero sus textos se refieren a un sistema propio que establece, así mismo, una conexión con la totalidad de la cultura moderna. Lezama lanza su sabiduría y un sistema potente de imágenes que redefinen los valores canónicos de las artes anteriores a él, además de ocuparse en los análisis de los bordes o márgenes de los periodos. Es decir, su crítica poética tiene un carácter liminal.

Los textos de Lezama también pretenden una racionalidad, que por sugerente y original, nos parece una seria propuesta estética que se desplaza por la lógica del texto. Pero detrás de esa primera lectura, de esa seriedad, está la risa sutil de un lenguaje propio intencionalmente indecodificable. La ironía de Lezama radica, en ocasiones, en presentar al lector una realidad casi vulgar, bajo un código profundamente erudito. De esta manera se logra un extrañamiento que nos hace reconsiderar la información. Así se presenta cada hecho estético como un hallazgo genuinamente novedoso. En otras ocasiones, la observación del poeta domina la perspectiva, y la narración se va prolongando hermosamente, distanciada por descripciones y explicaciones de imágenes.

Reviso primero algunas instancias donde el narrador se dirige directamente al lector. El juego de Lezama con el lector no es generalmente explícito, como en el caso de Borges, aunque no por eso deja de referirse al lector en ciertas ocasiones. La mención directa al lector es más fácilmente detectable en la narrativa. Por esta razón, y por el poco 
interés que se ha prestado a sus relatos, centro el análisis de esta sección en ellos fundamentalmente. En uno de los relatos titulado "El patio morado," el narrador se dirige al lector directamente de esta manera: "Dos infantes se destacaron del grupo. Dispensadme esta descripción rápida e imprecisa" (Relatos 36). A Lezama se le hizo necesaria esta acotación por la digresión voluntaria que antecede y que prosigue a la advertencia. En Lezama existe una voluntad de aprehender la realidad a través de imágenes que dilatan suavemente la narración. De todos modos, se observa aquí el elemento de ficción, cuando el narrador nos hace pensar que el desliz de precisión es de él, con respecto a un evento que tiene una precisión fuera del texto.

"El juego de las decapitaciones" es un relato ejemplar para observar el proceso mitificador en Lezama. Consecuente con su perspectiva microespacial, la narración de Lezama se llena de imágenes que explican su percepción y embellecen el texto. El narrador lezamiano no propone una retórica lógica, sino una retórica poética. Aquí también se da ese narrador que habla directamente con su lector, pero obsérvese primeramente el referente que nos desubica y nos remite a un telos legendario: "Wang Lung era mago y odiaba al Emperador; amaba en doblegada distancia a la Emperatriz" (47). El narrador propone una realidad que no nos implica, habitamos fuera de ella, y por tanto, funciona en nosotros como un cuento fantástico. Lezama usa frecuentemente este recurso en sus relatos, en su proceso mitificador. En la teoría arquetípica de Northrop Frye este uso es afín a "The Archetype of Arcadian Images" (Fables of Identity 20), que es sumamente caro a Lezama, como veremos posteriormente.

"El juego de las decapitaciones" sintetiza fábula y poesía de una manera magistral. El lector no se incomoda por las bellas descripciones que acompañan la escena 
de la fuga de la Emperatriz. Estas escenas decoran el cuento con la magia de un barroco chino, y originalmente lezamiano, a la vez. Véase la manera en que Lezama describe una aldea que se aproxima, durante la fuga del mago Wang Lung y la Emperatriz So Ling: "los grandes faroles de las casas más ricas, al moverse soplados por el viento del otoño, parecían pájaros que transportasen en su pico nidos de fuego" (Relatos 53). En una imagen híbrida entre esa geografía interior (y citadina) de la que habla Emilio de Armas ("La poesía del encuentro" 2), y un pretendido telurismo chino, Lezama nos recrea la escena del mito que elabora.

La narración se encarga de la Emperatriz So Ling, en su correr por los campos del norte. Su fuga en trineo es una escena bella, llena de descripciones casi estruendosas, y luego el narrador vuelve a recuperar el hilo de Wang Lung con una intervención directa al lector, cuando dice: "Retomemos de nuevo al mago Wang Lung, perdido, despreocupado gustoso por las provincias del norte" (Relatos 56). Lezama construye la ilusión de realidad con los elementos de la descripción. Su descripción detallada de los elementos del entorno nos hace pensar en una escena real. Su ficción de racionalidad se crea mediante un juego entre mirada e imaginación. La adjetivación del narrador lezamiano (despreocupado gustoso), nos hace confiar en la información del narrador y nos proporciona disfrute.

No me refiero a una descripción realista como leemos en Balzac o Stendhal, que se esfuerza por mostrar objetividad; en Lezama ocurre algo exagerado, extravagante por lo cargado de la imagen, que no pretende ser objetivo, sino decorar la realidad; crearla a través de la imagen. El narrador imagina, y expone despaciosamente, retardando el tempo de la narración. Pero en tales narraciones nos parece que la imagen es parte constitutiva 
de la propia acción. Sucede aquí como en el naturalismo, sólo que la ciencia ha pasado a ser poesía. Al narrador lezamiano le interesa explicitar la observación y en ella se completa esa ficción de racionalidad. Lezama refiere la narración a su mundo poético. Ejemplos de lo expuesto se pueden ver en "Fugados" (23), y "El patio morado" (42). Analicemos un ejemplo concreto, en la siguiente cita de "El juego de las decapitaciones": “[ . . ] los perros hundían su hocico en el agua para comer peces aún vivos, mezclándose el sonido de su masticación y el de la agonía de los peces" (54). La acotación "imaginal," al final del elemento narrativo que avanza la acción propiamente, es siempre entregada como elemento de verosimilitud.

La diferencia con la ficción de racionalidad borgeana es que en Lezama se aplica la perspectiva microespacial. La demostración no se dirige al hipertexto o corpus filosófico que trata (dilucida) el texto, sino que se disemina y actúa como pequeñas explicaciones, focalizadas y constreñidas a cada observación específica. En este sentido sugerí la imagen del brocal de pozo, al inicio de este estudio. La perspectiva lezamiana crea esos pequeños trozos demostrativos que se refieren a su sistema poético total. La demostración lezamiana es analógica y procede sobre la imagen.

La manera en que el narrador describe la escena de los perros es impactante y autoconsistente en sí misma. De golpe, a primera vista, resulta una observación aguda que no deja brecha a la duda. Sin embargo, cuando detallamos en la estructura metafórica de la frase, descubrimos los recursos fictivos con los que está compuesta. Al enfatizar el narrador que el sonido de la masticación de los perros se mezclaba con el de la agonía de los peces, esta añadiendo una realidad literaria, fictiva totalmente. Desde el punto de vista 
mimético es suficiente mencionar el sonido de la masticación. El naturalismo hubiera hecho énfasis en el chasquido producido por el hambre atroz de los caninos.

El narrador lezamiano nos añade un sonido extrasensorial, el sonido de la agonía de los peces. Este sonido es una imagen. Es la imagen terrible de la muerte. Cuando se lee la frase de golpe, el lector procede intelectivamente focalizando a los perros, luego al hocico y luego al proceso de fractura y destrucción de esa nueva entidad creada por la poesía: "los peces." El relato no necesita la magnificación de los peces a categoría de vida que se destruye; pero la totalidad del sistema poético lezamiano, sí. Indiscutiblemente, la frase nos remite a imágenes míticas como la muerte, el instinto de conservación y la agonía del caído. Lezama crea con esa imagen extrasensorial, añadida, una ficción de racionalidad.

La escena total es absolutamente verosímil y entrega una descripción impecable de la situación de fuga, desespero y hambre por las noches del norte chino. Pero la frase no es natural. No es una observación real. Es una imagen generada que sirve de vehículo a esa verosimilitud, porque nos remite al arquetipo. La "imago" lezamiana ha entregado una imagen arquetípica de la voracidad canina y de una escena de fuga. La idea está condensada por Lezama críticamente cuando dice: "La penetración de la imagen en la naturaleza engendra la sobrenaturaleza [. . .] frente al determinismo de la naturaleza el hombre responde con el total arbitrario de la imagen" (El reino de la imagen 358). Esta escena, a su vez, refuerza el concepto que sirve de tema al relato. "El juego de las decapitaciones" es parte del ciclo (lucha) vital y ocurre a todos los niveles. Los peces han sido víctimas esta vez; los perros, a su vez, lo son del conductor del trineo (conductor de sus vidas). 
Visto de esta manera, la simple descripción de una escena mínima sirve como fragmento diminuto que reproduce la imagen de todo el cuento. Parecido a lo sugerido por Jaime Alazraki, sobre algunos relatos de Borges, donde una parte del cuento es cifra del cuento todo (Versiones 31$)$, en este caso tenemos que una partícula de imagen genera, poéticamente, los preceptos míticos en que se basa toda la narración. Este efecto holográfico de la narrativa lezamiana es, sin duda, una de las afinidades con la escritura de Borges. Ambos proceden de manera distinta y con características genuinas, sumamente originales, pero compatibles.

Seguidamente a la imagen de los perros Lezama describe el decursar del viaje en trineo de esta manera: "[. . .] mientras el trineo sobre su propia única luz nocturna se nutría de una extensión infinita" (Relatos 54). Se observa otra vez el recurso de la imagen generando la realidad. La poesía ha invertido los órdenes de la realidad. Esta cita apunta a la ruptura de la relación causa y efecto, corroborando la tesis de Lezama de que la poesía "sumergida en el mundo prelógico, no sea nunca ilógica" (Eras imaginarias 33). El trineo, como función, está hecho para recorrer las infinitas distancias del hielo. Como imagen, se nos presenta como si las distancias funcionaran en la mente humana sugiriendo el concepto trineo. La relación arquetípica aquí está dada por la asociación distancia-trineo, en la cual la distancia nutre al trineo, otorgándole su función genésica. En lugar de ser un objeto para transportar, es un arquetipo que, por generación espontánea o por memoria mítica, surge de las distancias polares.

En estos relatos se muestra la intención mítica de varias maneras. El alejamiento de la inmediatez y la creación de un referente mítico, remoto, es uno de estos mecanismos. Respecto a esto debo hacer una salvedad. Al inicio de este estudio, 
mencioné cómo ese alejamiento de la realidad era uno de los elementos en que se fundaba mi intuición inicial a la hora de unir a Borges y a Lezama en una poética. No se me escapa que la crítica sobre Lezama esta dividida en dos tendencias, y entiendo que la mención de este elemento no me exime de caer, mediante este estudio, en una de ellas, o de ser ubicado de cualquier manera. Pero la ética intelectual debe cumplir su función postulativa.

Existe la perspectiva de los estudios marxistas, que presentan a un Lezama nacionalista, comprometido con su cultura y de alguna manera hasta costumbrista que prima dentro de Cuba. Por otro lado, se elabora un Lezama desafecto a la revolución cubana y casi disidente que es absolutamente enajenado de su circunstancia nacional. Ambas posiciones tratan de sobrecompensarse y autodefenderse (autosubsistir). Esto no es un beneficio a los estudios sobre el tema. En el análisis sobre Lezama hay que tener en cuenta características múltiples que lo hacen un caso complejo de analizar. La base fundamentalmente religiosa del grupo Orígenes, que Lezama nunca abandonó; su personalidad, sui generis, que no se amoldaba a los cánones falocentristas de la sociedad cubana; su fe en un mejoramiento de la Cuba republicana y su comprometimiento con el arte como teleología que nunca conoció concesiones. En este estudio se han revisado algunos de los criterios de Cintio Vitier que definen la posición del grupo orígenes con respectos a otras tendencias que le circundaban.

En mi modelo, parcial y específico, sobre poética, demuestro los recursos de formación mítica en Lezama escogiendo, como toda crítica, una porción de la obra del autor, representativa del modelo que sostengo. Los relatos de Lezama fueron, casi en su mayoría, escritos en la época en que Borges desarrolló sus relatos de mayor éxito: las 
décadas del 30 al 50. Ésta es la simetría de la comparación. Otra posible objeción a la demostración sería plantear que los relatos no son escritura representativa del autor, lo cual me parece sencillamente insostenible. Sería como negar la capacidad de poeta de Borges, por el simple hecho de haberse hecho famoso como narrador. Los relatos de Lezama son textos válidos y de una calidad indiscutible, tanto como los muchos relatos que conforman las novelas "Paradiso" y Oppiano Licario, como ha visto Reynaldo González (Lezama, Relatos 15).

Retomando la intención mítica, me concentro mayormente en los relatos, donde Lezama muestra una mayor condensación metafórica a este respecto. En el primer cuento del libro, "Fugados," Lezama comienza con una imagen casi bíblica: "No era un aire desligado, no se nadaba en el aire. Nos olvidábamos del límite de su color, hasta parecer arena indivisible que la respiración trabajosamente dejaba pasar. Llovía, llovía más, y entre lluvia y lluvia lograba imponerse un aire mojado, que aislaba [. . .]" (Relatos 19). El narrador de este relato parece postergar eternamente las claves de la narración. El inicio se presenta como una narración blanca, neutra sin referente espacial o temporal.

La acumulación descriptiva posterga el paso de la acción. Los procesos perceptivos del narrador-observador se encargan de ir construyendo, sintagma a sintagma, el significante espacial. En la cadena sintáctica se sobreponen, en ocasiones, frases contradictorias como es el caso de la imagen del aire: "No era un aire desligado, no se nadaba en el aire." Luego el proceso de observación nos entrega la idea de un mar de gotas. Gotas de agua como arena, como aire minuciosamente fragmentado, como aire en el cual se pudiera nadar, pero no se nadaba. Hasta que el lector logra unir los fragmentos magnificados de una observación microespacial, y con esa perspectiva que da la 
“distancia", en este caso la acumulación imaginal de la lectura pasada, se construye la escena y logra nitidez.

El regateo de las claves de comprensión proponen un juego con el lector. Lezama se está comunicando, de esta manera, con nuestro trasfondo cultural. Después de haber sugerido la idea subliminal de su observación, considerando que la narración se debe comenzar por ese elemento, el narrador nos informa que llovía. Con esta declaración se conceptualiza la observación anterior. Lezama aprovecha la acumulación nemónica de imágenes y rasgos del evento para completar la escena. El narrador Lezamiano ha recreado, desde su memoria, el proceso por el que percibimos el "llovía." La lluvia, según el narrador lezamiano en este relato, es un proceso indirecto, fragmentado, desligado. Pero la lluvia es aquí también un proceso mnemónico, arquetípico, que nos sugiere la primera lluvia "prelógica," que observó el primer hombre sin corrupción del concepto.

Este recurso de regatear marcadores referenciales está asociado al proceso de arquetipización lezamiano. He mencionado que Julio Cortázar fue uno de los primeros en observar esta característica, de la prosa en Lezama, de crear arquetipos ante que tipos literarios ("Para llegar a Lezama Lima." 136). Otros relatos pueden darnos una perspectiva más "clásica” del proceso mitificador del narrador lezamiano. "El guardián inicia el combate circular" comienza con una introducción que contiene esta característica "desmarcadora" de la que venimos hablando. Observemos la introducción del relato, donde se asienta el tono de la narración total del relato:

Lo hecho para perseguirse comienza con un maullido. Y la esterilidad de los vacilantes senadores descorre ese maullido como trasciende la joven 
cabeza de tortuga entre la yerba antidiluviana. Así de sus senos, de sus cinturones blanduchos, almirabarados (sic), fluye una simpatía discreta, como un suspiro entre dos columnas, como la joven tortuga entre los yerbazales indios, [...] (85).

Este es un relato de difícil interpretación por la falta de jerarquía en el referente, a pesar de tener excesivas claves referenciales. En ocasiones nos sugiere el argumento de un perro guardián persiguiendo a un gato. A esta interpretación ayudan varios elementos: la repetición del vocablo maullido, las alusiones al hocico, el tema de la persecución y la imagen de la espina dorsal vigilada.

Cualquiera que sea la interpretación, la persecución de dos entes del reino animal parece ser una idea recurrente que define el argumento del relato. Analizando la cita inicial del cuento, vemos que el narrador nos refiere a un telos arcaico, legendario. Tal telos es la imagen de la cabeza de tortuga que trasciende entre la yerba antidiluviana. Esta imagen se puede asociar a lo que Northrop Frye denomina "the archetypes of arcadian images" (Fables of Identity 20). El narrador establece aquí una especie de topografía mito-(teo)lógica. La carga significacional de la tortuga como símbolo temporal esta asociada a la yerba antidiluviana, de manera que se refuerzan los significados. La idea de que "la tortuga trasciende," se puede interpretar de dos maneras.

En el sentido literal la tortuga procede, avanza; pero simbólicamente, trascender, es también sobrevivir, "pervivir" más allá de la yerba antediluviana. Están los dos significados concomitando en la idea de la perpetuación. Donde la tortuga sobrevive a la catástrofe bíblica (diluvio) y llega a nuestros días. Se pudiera entender la imagen, de nuevo, como cifra de todo el relato, donde los animales que hoy se representan en el 
mismo, han llegado hasta nosotros porque han tenido la misma capacidad de la tortuga. Esta característica de Lezama que hemos visto en "El juego de las decapitaciones," y que se repite en el relato que analizamos, y en muchos otros, es afín a la idea que sigue Borges en sus relatos. La diferencia es que la cifra del cuento, en Lezama, es una cifra profunda a nivel de imagen. Pero, de todos modos, es el mecanismo matricial que regenera toda la figuratividad lingüística de sus textos.

Las asociaciones que el narrador lezamiano indica dan a su narrativa una polisemia casi infinita. La imagen temporal, al ser asociada con el tema del relato, nos propone interpretar el tema como algo eterno, recursivo. La falta de referentes que jerarquicen una interpretación específica nos mantiene en el concepto arquetípico de la persecución, sin que podamos definir una persecución concreta. Lezama evita establecer jerarquías violentas en cuanto a los referentes (Selden 105), siendo consecuente con la deconstrucción de las relaciones causa-efecto, y estableciendo un extrañamiento, respecto a nuestra interpretación cultural. Por esta razón, no es gratuito que se reitere la imagen de la tortuga "entre los yerbazales indios."

El mito se logra aquí con dos recursos fundamentales, a través de la memoria, por cuanto ésta es el vehículo de todo el bagaje cultural asociativo, y por la referencia a un lenguaje bíblico (prístino), que deviene mito de las sociedades, humana y "animal”. Las observaciones minuciosas que se presentan en el texto son producto de un esfuerzo intelectual de recreación poética, más que de una mimesis genuina. A este proceso de recreación se refiere Lezama cuando dice: “Decididos a traer todas las plantas a nuestro jardín, miramos en torno con el convencimiento rotundo del bosque, olvidando [. . .] que el bosque no es tan sólo lo que no se ve, sino lo que no existe: un encantamiento" (La 


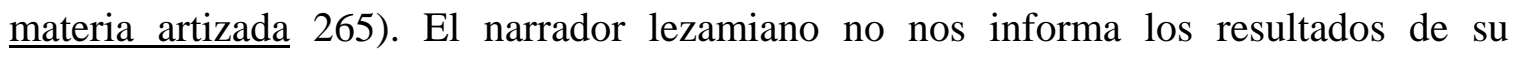
observación, nos forma en la disciplina de la imagen. Este narrador crea una realidad que procede de la información del individuo como cultura, es metafictiva y metacultural.

Esto se comprueba mediante las asociaciones de elementos dispares y la referencialidad de la observación a elementos propios de la cultura. Se puede ver un claro ejemplo de este tipo de descripciones (sumas), cuando el narrador del cuento en cuestión focaliza la mirada del "animal prolongado, de hocico felino." El narrador nos dice: "Ha estado en las grutas donde los peces con los descensos de las mareas se han ido incrustando en los paredones, y sus uñas de madera raspan despiadadamente aquellos cuerpos volcados con hondura insaciable sobre las piedras, pero donde todavía una espina, un ojo rebanado guardan una cultura marina con celo y ardor" (Relatos 86). El narrador desborda las posibilidades del animal de hocico felino. La observación tiene una fuerte connotación cultural. El trasfondo de historia y de procesos naturales de mareas y descomposiciones, de ciclos de vida y muerte es sencillamente sobrecogedor de la escena. En esta ocasión, el narrador lezamiano ha operado un recorrido natural (biológico), semejante al recorrido histórico-científico que realiza Borges en el caso estudiado de "La doctrina de los ciclos," en la página 91 de este estudio.

Esta construcción arquetípica, en que se presenta un referente remoto o mítico (metafictivo), se puede hallar en muchos relatos de Lezama. A modo de ejemplo cito a continuación algunos inicios de relatos que reflejan lo que he venido explicando anteriormente. En "Para un final presto" Lezama relata sobre la secta El secuestro del tamboril por la luna menguante, donde un grupo de jóvenes, discípulos de Galópanes de Numidia, planeaban un suicidio colectivo. El narrador comienza de esta manera: "Una 
muchedumbre gnoseológica se precipitaba desembocando con un silencio lleno de agudezas, ocupa después el centro de la plaza pública" (73). Para la perspectiva del lector caribeño, la descripción presenta un referente mítico por la propia naturaleza de la acción, por la selección de palabras (gnoseológica) y por la falta de marcas temporales.

En "Tangencias" Lezama comienza con un tema caro a Borges: "Después de haber inventado el cero, el príncipe Alef-Cero marchó a caballo hasta que el sueño le fue entrecruzado lanzándolo del caballo hacia la yerba cubridora de blancas rocas espongiarias" (125). De nuevo, nos encontramos ante el tema onírico-metafísico, donde el componente mítico es la fundamental carga referencial del relato. Las indagaciones estéticas y gnoseológicas de Borges y Lezama se encuentran en este tipo de construcciones. Más que relatar, estos relatos proponen imágenes, cavilaciones, retóricas de una cultura que se repite y se relee.

En "Pífanos epifanías cabritos" el narrador nos remite al mito de la creación del mundo: "Se ponían claridades oscuras. Hasta entonces la oscuridad había sido pereza diabólica y la claridad insuficiencia concreta de la criatura" (117). Lezama comienza la narración por el origen del mundo, como si el origen nos fuera desconocido. Los temas de la luz y la sombra tienen una carga mítica original que es usada por el narrador para crear su ficción de racionalidad. Ésta, en este caso, no pretende una demostración lógica al estilo de la retórica borgeana; sino una demostración prelógica, poética, que como dice Lezama, no es nunca ilógica (Eras imaginarias 33). Lezama sigue un procedimiento de demostración por imágenes.

Obsérvese un último ejemplo en ese tipo de referente mítico con el que vengo ilustrando la ficción de racionalidad en Lezama. Éste es el caso del relato "Cangrejos, 
golondrinas." En este caso el oficio, la nominación y la referencia ancestral del protagonista, aluden a lo helénico: "Eugenio Sofonisco, herrero, dedicaba la mañana del domingo a las cobranzas del hierro trabajado. Salía de la incesancia áurea de su fragua y entraba con distraída oblicuidad en la casa de los mayores del pueblo" (Relatos 95). Con este último ejemplo vemos cómo Lezama mantiene los rasgos de su escritura a través de diferentes temas. En este caso el referente sigue siendo metafictivo, hecho de una serie de pastiches e ideas sueltas en la cultura y en la creencia de esos pueblos arcaicos y sus oficios.

De modo que, en este sentido, la prosa narrativa de Borges sigue más el estilo de demostración científica, ayudado por la retórica de la demostración, la lógica convertida en retórica a la que se refiere Paul De Man en su teoría (cit en Selden 112). Borges demuestra con esto, de manera práctica, que la lógica del discurso científico, histórico, religioso, o de cualquier otra índole, es ficticia y se ajusta a los métodos de alegoría expuestos por Paul De Man (112), demostrando así, mediante su obra, los preceptos del logocentrismo y la deconstrucción. El éxito de Borges radica en haber comprendido y usado en sus escritos esta corriente de pensamiento actual.

Lezama, por su parte, ha creado un lenguaje poético, diferente, donde establece una lógica metafórica. La concatenación de imágenes en la prosa de Lezama explica el mundo y nuestra manera de aprehenderlo. Lezama indaga internamente en el proceso mimético y epistemológico del lenguaje, en sus posibilidades de articulación, demostrando una manera diferente de organizar las estructuras arquetípicas y conceptuales mentales. Lezama nos entrena en "otra forma de ver" y de "almacenar" esos productos en la memoria. Su método también contiene al logocentrismo y a la 
deconstrucción, ya que nos llama la atención sobre la ambigüedad de cada concepto y de cada imagen, al ponerlas en contextos extraños y en interrelaciones nuevas. La prosa de Lezama apunta a las concepciones de mala lectura o "misreading" (Selden 112), y a los conceptos de las teoría de la recepción.

Dentro de este capítulo de ficción de racionalidad el humor es también un elemento importante. El elemento de humor se une a los ejemplos de inclusión del lector en la narración como recurso fictivo. En el relato "Para un final presto" Lezama dice: "Más tarde, al recibir una beca en Yale para estudiar el taladro en la cultura eritrea en reación (sic) con el culto al sol en la cultura totoneca, había aclarado esa frase, [. . . ] Un insignificante estudiante de filosofía de Yale, que presumía que había frustrado su vocación, pues el quería ser protestante y poseer una cría de pericos cojos del Japón" (Relatos 77). El humor culto de Lezama es un punto de contacto con las carcajadas borgeanas que asoman en cuentos como "Pierre Menard, autor del Quijote," en la enumeración de la obra visible de Pierre Menard, que el narrador había "examinado con esmero." Recordemos en esta enumeración de la "a" a la "s", la serie de claves cultas destinadas a un efecto hilarante en el relato (Obras completas 1:444-445).

El humor de Borges, en el cuento referido, establece datos inverificables, muchas veces por el origen trivial de éstos. Tal es el caso del "artículo técnico sobre la posibilidad de enriquecer el ajedrez eliminando uno de los peones de torre" que "Menard propone, recomienda, discute y acaba por rechazar" (445). Menard deconstruye su propia idea. En el caso del cuento de Lezama, "Para un final presto," se quieren estudiar el taladro en la cultura eritrea y el culto del sol en la cultura totoneca. El humor, en ambos 
casos, se logra mediante un dato culto que parece sinsentido. La cultura libresca que nutre ambas poéticas es la base de este humor ilustrado.

El relato que nos ocupa continúa con toques de humor: "Los estoicos se iban trocando en cejijuntos, aunque no en malhumorados (Relatos 77). Lezama parece describir una escena de cierta gravedad, desde el punto de vista de su propósito. Sin embargo, el efecto hilarante de la narración se va logrando con toques intermitentes y tenues. La ironía de Lezama consiste en perder al lector en sus propias claves metafóricas. El humor, la referencia directa al lector, y las descripciones metafóricas sumamente elaboradas y bellas son la recompensa que el autor entrega por tan ardua tarea de entregarse a la obra. Todos estos elementos denotan un goce estético depositado con cuidado en los textos.

En "Invocación para desorejarse" el narrador nos dice: "Para que el sombrero pudiese entrar en mi testa, decidieron cortarme las dos orejas. Admiré sus deseos de exquisita simetría, [. . .]" (135). Este es un relato expresamente cómico, muestra una mezcla de absurdo con escenas de plasticidad humorística. Otro ejemplo del humor lezamiano en los relatos es el del "peso del sabor," donde el narrador, en primera persona, nos describe desde su boca: "Sentado en mi boca asisto al paisaje. La gran tuba alba establece musitaciones, puentes y encadenamientos no espiraloides" (121). Aquí se observa un humor absurdo también; pero la poesía entra a complicar las cosas y presentar una especie de naturalismo barroco de gran elaboración.

Por la poca difusión que han tenido los relatos de Lezama y por la escasa crítica que existe sobre ellos, le he dado a esta sección un estilo enumerativo, donde, a la vez que realizo el análisis textual, informo sobre la naturaleza de los cuentos. Creo que vale 
la pena dedicar esfuerzos posteriores dirigidos a estos relatos, por cuanto revelan características difíciles de detectar en otras manifestaciones de la obra de Lezama. Debo aclarar, de todos modos, que estos recursos se encuentran en Paradiso y en Oppiano $\underline{\text { Licario, }}$, como hemos visto parcialmente en la sección sobre el neobarroco.

Hemos visto cómo la ficción de racionalidad se expresa en Lezama mediante varios recursos. Uno de ellos es la recreación de una topología retirada a tiempos remotos que nos descontextualiza el referente. Otro recurso es la narración desde la memoria como producto cultural. Este recurso crea la ilusión de textos porosos a que se ha referido José Miguel Oviedo (129) en los textos de Borges. El tercer recurso que contribuye a lograr la ficción de racionalidad es ese narrador que en ocasiones se dirige directamente al lector, y en otras ocasiones, se ríe detrás de la página con un humor culto que produce una "ruptura de sistema." Por último, se percibe una tendencia en la narración lezamiana, a referir toda escritura a su sistema poético. Este recurso hace que en porciones pequeñas de la narración se dé la cifra de la narración completa. 
4. - Conclusiones

Las poéticas de Borges y Lezama ha sido el centro de este estudio. El recorrido lógico del mismo fue como sigue: relaciones extraliterarias de ambos autores, características peculiares que ambos comparten, estilo neobarroco y diferencias de barroco textual, y por último, el carácter fictivo y no mimético de sus estéticas, logrado a través de la memoria como archivo del registro cultural. De la primera instancia de la demostración se pueden extraer conclusiones parciales. Es decir, existe un grupo de evidencias que nos apuntan a un conocimiento literario de la obra de Borges por parte de Lezama. Pero en el caso de Borges, sólo podemos asumir su conocimiento sobre los textos específicos del autor cubano; una asunción sumamente fuerte, por la relación de Borges con $\underline{\text { Sur, Anales de Buenos Aires, }}$ y la conexión de estas publicaciones con la literatura cubana, a través de Orígenes, de Virgilio Piñera, de Silvina Ocampo y de José Rodríguez Feo.

Hemos podido comprobar mediante las citas de Lezama sobre la obra de Borges, que éste seguía minusiosamente el desarrollo del argentino. Esta evidencia demostró también que la estética de Borges y sus opiniones generales sobre la cultura y el proceso escritural son afines a Lezama. El capítulo total se denomina "Escritores sui géneris," y efectivamente el objetivo fue comprobar la peculiaridad de ambos escritores respecto a varias características. La primera sección del capítulo, de la que vengo hablando, es impresindible en el estudio para discriminar influencias directas, en tales afinidades poéticas.

No se puede afirmar que entre Borges y Lezama se den evidentes intertextualidades mutuas en el plano literario. Existen infinidad de conexiones temáticas 
motivadas por preocupaciones teológicas, metafísicas y estéticas comunes. Asumo el conocimiento de las obras respectivas en ambos casos. Sin embargo, las preocupaciones de Lezama son tan originales y constitutivas de su poética, como las de Borges. Por tal razon, me niego a considerar la influencia en una dirección. Este motivo y los estilos sumamente peculiares, respectivamente, permiten concluir que las afinidades residen en otras causas. Pudieramos, por el momento, pensar en causas de índole epocal, como esos arquetipos que nos sugieren formas de pensamiento, o la afirmación de ambos autores dentro de una renovación formal y una jerarquización del componente hedónico en la literatura.

La segunda sección del primer capítulo, "Los raros," permitió ver características extratextuales y textuales que unen estas poéticas polares. Borges y Lezama comparten múltiples semejanzas. Existe un eje fundamental de preocupaciones que tienen que ver con una jerarquización del elemento fictivo. Ambos escritores ven la literatura como toda la realidad. El énfasis del sentido hedónico de la literatura establece un compromiso literario con la calidad y con la educación del lector. A su vez, esta jerarquización va en detrimento de una literatura "útil" o comprometida con otros valores extraliterarios inmediatos o directos. Podemos decir que las indagaciones de ambos autores que nos ocupan tienen un gran componente teleológico y epistemológico que usa como conducto de esas preocupaciones el texto literario.

En la época en que se desarrollaron las obras de Borges y Lezama esa condición meta-estética fue rara, respecto a la generalidad de las manifestaciones literarias y artísticas. En una época de efervecencia de movimientos sociales y revolucionarios, donde la teoría marxista era común entre los intelectuales, Borges y Lezama se apegaron 
a otras lealtades. En esa dirección iba dirigida la crítica de Virgilio Piñera sobre el carácter enajenado de las obras de Borges y Lezama. Las lealtades de los escritores que nos ocupan sentaban raíces en la cultura occidental como tradición.

Lezama venía de un pensamiento religioso que, combinado con el carácter liberal de las humanidades, se transformó en un sistema poético sistémico (panmetafórico), con elementos de paganismo y amalgama de todas las culturas. Borges con su carga occidental y latinoamericana desarrolló un sistema semejante, pero al faltar el elemento religioso, y ser éste sustituido por el escepticismo epistemológico, desarrolló un trato irónico y metafictivo de toda la cultura. Ambos coinciden en su rareza al establecer un sistema literario comprensivo, que busca nuevas formas de expresión. Su esencialismo latinoamericano consiste en ir más allá de la corriente de un momento histórico, o de condiciones circunstanciales temporales determinadas, y fundar un sólido cuerpo mítico para las letras del continente.

Esas construcciones de sistemas poéticos se asientan en los textos específicos mediante visiones y recursos determinados que se plasman en el texto. El capítulo "Poética barroca: macroespacialidad/microespacialidad" me permitió ver en detalle esas características en ambos casos. Borges imita un discurso lógico, propio de las ciencias o las disciplinas analíticas. Lezama usa una retórica donde la metaforización es barroca. En lo que pudiéramos llamar recursos barrocos externos, ambos comparten el uso de recursos como las enumeraciones caóticas, las condensaciones, el oximoron y la hipálage. Éste es el baroco común a ambos. El estilo que los diferencia está dado por la perspectiva microespacial lezamiana y la perspectiva macroespacial borgeana, como características fundamentales. 
La perspectiva macroespacial en Borges tiende a la comprensión del hipertexto cultural, a partir de sus marcadores externos. Borges crea la ficción con elementos fictivos reconocibles y asociados a autorías o escuelas de pensamiento filosóficas o teológicas. La perspectiva microespacial de Lezama también es omnicomprensiva, pero atiende a los marcadores internos de la ficción. La ficción de Lezama considera el archivo de imágenes acumulado en la cultura. Su microespacialidad no juega fictivamente con títulos, pensadores o ecuelas filosóficas explícitamente, al estilo de Borges, aunque en su discursividad poética se consideren éstas como partes de la forma de ver al mundo.

En esto consiste la ficción de racionalidad de ambos. Tanto Borges como Lezama pretenden mostrar una erudición en el texto y esta erudición crea un lenguaje que intenta explicar la realidad. El escepticismo decostructivo de Borges presenta la racionalidad como un contrasentido, mientras que el sistema poético de Lezama, basado en la imagen, muestra la realidad como una combinación creada por la poesía. Para ambos, ficción de racionalidad es jerarquizar la importancia del arte y crear un referente lingüístico que asienta el mito, a partir de ser construido con elementos culturales. Como bien observa Mark Richard Couture: "Borges was a writer who wrote about his readings. The same can be said of Lezama." (Secret Accomplices 290).

La relación polar que existe entre Borges y Lezama se ha visto en los diferentes ángulos de análisis. Las condicionantes históricas en Borges concuerdan con la visión macroespacial, y su comprensividad cultural desde esa perspectiva, también son compatibles. En el análisis textual de sus obras se ha observado que la perspectiva macroespacial es tan tangible en los textos borgeanos que alcanza casi la cualidad de 
topografía. En este sentido he hablado de la sicografía. Esta sicografía borgeana es macroespacial.

Las condicionantes históricas y telúricas también concuerdan en Lezama con su microespacialidad. El grupo Orígenes indagó intensamente en los conceptos de insularidad. También tuvo este grupo varios representantes de la geografía interior que he revisado, como es el caso de Eliseo Diego. Lezama está en el centro de estas preocupaciones que miran a una geografía urbana. En el cosmos simbólico de Lezama esta semántica urbana se mezcla con un simbolismo criollo rural, que sirve de elemento fictivo y coadyuba al concepto de identidad cultural. Por otra parte, la propia biografía de Lezama también refuerza esas condicionantes que desarrollaron en él su perspectiva micrespacial. Lezama muestra esta visión en su poesía, en sus ensayos y en toda su narrativa.

En conclusión, pienso que el modelo polar es sumamente efectivo para entender la relacion dinámica que existe entre ambas poéticas dentro del sistema de las letras hispánicas. Quedan por abordar estudios respecto a los arquetipos en ambos escritores, así como indagaciones biográficas más profundas en cuanto a la posible relación entre ellos. Este estudio se une a esa línea que viene investigando a dos representantes importantes de las letras modernas, que además, no fueron del todo reconocidos en vida. Me encuentro ante la ambigüedad de concluir una propuesta teórica que sólo comienza. Pues las fuentes de ceatividad que le sirven de objeto de estudio son infinitas. 
Obras citadas

Aguiar e Silva, Víctor Manuel de. Teoría de la Literatura. Trad. Valentín García Yebra. Madrid: Gredos. 1975.

Allison et all. Colleridge 252.

Alazraki, Jaime. "Borges o la ambivalencia como sistema.” Lafuente 11-22.

---, ed. Jorge Luis Borges: El escritor y la crítica. Madrid: Taurus. 1976.

---, Int. y comp. Critical Essays on Jorge Luis Borges. Boston: G. K. Hall. 1987. 1-20.

---. La prosa narrativa de Jorge Luis Borges. Gredos, Madrid. 1968.

---. “Oxymoronic Structure in Borges' Essays.” The Cardinal Points of Borges. Eds. Lowell Dunham e Ivar Ivask. University of Oklahoma Press. 1971. 47-53.

---. Versiones. Inversiones. Reversiones: El espejo como modelo estructural del relato en los cuentos de Borges. Madrid: Gredos. 1977.

Álvarez Bravo, Armando. “Orbita de Lezama Lima.” Voces 9-29.

Arenas, Reinaldo. Antes que anochezca. 5ed. Barcelona: Tusquets. 1995.

Armas, Emilio de. "La poesía del encuentro en Las miradas perdidas, de Fina García Marruz". Encuentro de la cultura cubana. Madrid: 11 (Invierno 1998-1999): 1622.

---. Introducción. Lezama. Poesía 13-64.

Arrufat, Antón. “Las estaciones de una amistad.” Espinosa 138-160.

Bartucci, Giovanna. Borges: A Realidade da Construção. Literatura e Psicanálise. Trad. Sylvio Horta. Rio de Janeiro: Imago. 1996.

---. "Entre o mesmo e o duplo, inscreve-se a alteridade. Psicanálise freudiana e escritura borgiana." Psicanálise, Literatura e Estéticas de Subjetivação. Comp e introd. Giovanna Bartucci. Rio de Janeiro: Imago. 2001: 369-385

Bejel, Emilio. “Cultura e Historia en Carpentier y Lezama Lima.” Letras Cubanas 12.3 (julio/diciembre 1989): 237-257.

Bell-Villada, Gene H. Borges and his fiction: A guide to his mind and art. Revised Ed. Austin: University of Texas Press. 1999. 
---. "Lezama o las equiprobabilidades del olvido." Hispamérica 25-26 (1980): 22-37.

Borges el memorioso: Conversaciones de Jorge Luis Borges con Antonio Carrizo. México: Fondo de Cultura Económica (1983).

Borges, Jorge Luis. Obras completas. 4 tomos. Mallorca: Emecé editores. 1996.

---. La Cifra. Buenos Aires: Emecé. 1983.

---. Ficciones. Madrid: Alianza editorial. 1991.

---. El hacedor. Madrid: Alianza. 1996.

---. Historia de la eternidad. Madrid: Alianza. 1994.

---. Historia universal de la infamia. Bueno Aires: Emecé Editores. 1935.

---. Historia universal de la infamia. Buenos Aires: Emecé Editores. 1954.

---. Obra poética. Buenos Aires: Emecé. 1985.

---. Otras Inquisiciones. Madrid: Alianza editorial. 1993.

---. Páginas Escogidas. sel. y prol. Roberto Fernández Retamar. La Habana: Casa. 1988.

Burgin, Richard. Conversation with Jorge Luis Borges. London: Souvenir. 1973.

Camacho-Gingerich, Alina. La cosmovisión poética de José Lezama Lima en Paradiso y Oppiano Licario. Miami: Universal. 1990.

Camayd-Freixas, Erik. Realismo Mágico y Primitivismo. Maryland: University Press of America. 1998.

Carpentier, Alejo. El reino de este mundo. Barcelona: Seix Barral. 1983.

Coleridge, Samuel Taylor. Ed. Allison et all. The Norton Anthology of Poetry. New York: W.W.Norton. 1975: 252-53.

Cortázar, Julio. "Para llegar a Lezama Lima.” La vuelta al día en ochenta mundos. México, Siglo XXI, 1967. 135-155.

Couture, Mark Richard. "El agua más recordada: Golden Age Poetry in Lezama's 'Ah, que tu escapes'." Hispania 1 (March 1997): 20-30. 
---. Secret Accomplices: Jorge Luis Borges and Jose Lezama Lima read the poetry of the Spanish golden age. Department of Romance Languages. Duke University. 1995.

Dunham, Lowell and Ivar Ivask, ed. The Cardinal Points of Borges. University of Oklahoma Press. 1971.

Espinosa, Carlos. ed. y comp. Cercanía de Lezama Lima. La Habana: Letras Cubanas. 1986.

Fernández Retamar, Roberto. "Perpetuo Gerifalte, Escándalo Bizarro.” Espinosa 117128.

Frye, Northrop. Anatomy of Criticism. New Jersey: Princeton University Press. 1973.

---. Fables of Identity: Studies in Poetic Mythology. New York: Harcourt Brace. 1963.

---. The Great Code: The Bible and Literature. $5^{\text {th }}$ ed. San Diego: Harcourt Brace. 1983.

Fuentes, Carlos. La nueva novela hispanoamericana. México D.F.: Joaquín Mortiz. 1997.

García Marruz, Fina. Serie Valoración Multiple. La Habana: Letras Cubanas. 1970.

Glantz, Margo. Intervención y pretexto. México: UNAM. 1980.

González Cruz, Iván, sel. y prol. Fascinación de la memoria: textos inéditos de José Lezama Lima. La Habana: editorial Letras Cubanas. 1993.

González Echevarría, Roberto. "Memoria de apariencias y ensayo de Cobra." $\underline{\text { Severo } 63-}$ 86.

González, Reynaldo. "Lezama a la altura de los ojos.” Espinosa 210-230.

Gonzalez, Reynaldo. Lezama. Relatos. Introducción 9-16.

Guillén, Claudio. Teorías de la historia literaria. Madrid: Espasa-Calpe. 1989. Huerta, David, "Prólogo: Trece motivos para Lezama." Lezama, Muerte de Narciso: antología poética 7-29.

Juan-Navarro, Santiago. "Entre el revisionismo histórico y la literatura de resistencia: La ambigüedad posmodernista de los novelistas del 'Boom'." Journal of Interdisciplinary Literary Studies 7. 2 (1995): 181-205. 
---. "Las formas secretas del tiempo: 'Tema del traidor y el héroe' y la metahistoria." Reflections on the Conquest of America: Five Hundred Years After. Fifth Biennial Northeast Regional Meeting. Durham: University of New Hampshire. (1996): 23-33.

Jung, Carl Gustav. "On the Relation of Analytical Psychology to Poetry.” The Critical Tradition: Classic Texts and Contemporary Trends. Ed. David H. Richter New York: St. Martin's Press, 1989.

Lafuente, Fernando R. España en Borges. Madrid: El arquero. 1990.

Levine, Suzanne Jill. "Borges a Cobra es baroc(o) (exé)gesis: un estudio de la Intertextualidad." Severo Sarduy 85-105.

Lezama Lima, Eloisa. Introducción. Paradiso 13-94.

Lezama Lima, José. Coloquio internacional sobre la obra de José Lezama Lima: prosa. Francia: Universidad de Poitiers. 1984.

---. "Conferencia sobre Manuel de Zequeira y Manuel Justo de Rubalcaba." González Cruz 61-89.

---. El reino de la imagen. Caracas: Biblioteca Ayacucho, 1981.

---. Eras imaginarias, Madrid: Fundamentos. 1971.

---. La Cantidad hechizada. La Habana: Ediciones UNEAC. (1970): 341-360.

---. La expresión americana. Madrid: Editorial Alianza. 1969.

---. La materia artizada. Comp. y Prol. José Prats Sariol. Madrid: Tecnos. 1996.

---. Muerte de Narciso: antología poética. Ed. y prol. David Huerta. Madrid: Alianza. 1988.

---. Oppiano Licario. ed César López. Madrid: Cátedra. 1989.

---. Paradiso. Ed. e introd. Eloísa Lezama Lima. Madrid: Cátedra. 1995.

---. Poesía. Ed. e intr. Emilio de Armas. Madrid: Cátedra. 1992.

---. Poesía completa. Ed. y prólogo César López. Madrid: Alianza. 1999.

---. Relatos. Madrid: Alianza Editorial. 1999.

López, César. Introducción. Lezama, Oppiano Licario 11-102. 
López, James J. "El Barroco americano en el modernismo: el pensamiento estético de Martí y Herrera y Reissig." Taller de Letras 27 (1999): 33-52.

Martínez, Luz Ángela. "Manierismo y Neobarroco: Genealogía de una crisis". En Revista de la Facultad de Filosofia y Humanidades Univ. de Chile. No. 14 Otoño. 2000. http://www.uchile.cl/facultades/filosofia/publicaciones/cyber/cyber14/tx24lamarti nez.html.

Menton, Seymour. El cuento Hispanoamericano. $2^{\text {nd }}$ reimpresión. México: Fondo de Cultura Económica. 1997.

---. “Jorge Luis Borges, Magic Realist” Hispanic Review 50. 4 (1982): 411-26.

Merriam-Webster's Collegiate Dictionary. 10 ${ }^{\text {th }}$ Ed. Springfield: Merriam-Webster. 1993.

Orígenes. Rodríguez Feo y Lezama Lima ed. y dir. 2.6 (1945).

Ortega, Julio. “Lezama, hoy y mañana.” Espinosa 247-250.

Ortega, Julio. "Valoración de la obra de Lezama Lima." www.akademie-solitude.de/projekte/Lezama/valoracion/valora.html. En Onix Acevedo; Stuttgart. 1997.

---. “La biblioteca de José Cemí. Revista Iberoamericana 41.92-93 (1975): 509-21.

---. “'El Aleph’ y el lenguaje epifánico.” Hispanic review 67. 4 (1999): 453-466.

Oviedo, José Miguel. "Borges: The Poet According to His Prologues." Borges the Poet. Ed. Carlos Cortínez. Fayetteville: The University of Arkansas Press. 1986. 121133.

Pellón Gustavo. José Lezama Lima’s Joyful Vision. Austin: University of Texas Press. 1989.

Piñera, Virgilio. “Cartas de Virgilio.” González Cruz 261-284.

---. "Nota sobre literatura argentina de hoy.” Orígenes 4.13 (1947): 40-45.

Rensoli, Lourdes e Ivette Fuentes. Lezama Lima: Una cosmología poética. Habana: Letras Cubanas. 1990.

Rodríguez Coronel, Rogelio. "La novela cubana contemporánea: alternativas y deslindes". Revista Iberoamericana 152-153. 56 (Julio-Diciembre, 1990): 899912. 
Rodríguez Feo, José. Mi correspondencia con Lezama Lima. Habana: UNEAC, 1989.

Salgado, César Augusto. "Barroco Joyce: Jorge Luis Borges's and Jose Lezama Lima's antagonistic readings." Transcultural Joyce. Lawrence, Karen R. Ed. e introd. England: Cambridge UP. (1998): 63-93.

Sarduy, Severo. Antología. Prol. Gustavo Guerrero Jiménez. México D.F.: Fondo de Cultura Económica. 2000: 143-146.

---. "El barroco y el neobarroco" América Latina en su literatura. Intr. César Fernández Moreno. Unesco. 1972. 166-184.

---. “Carta de Lezama.” Voces. 33-41.

---. La simulación. Caracas: Monte Avila. 1982

---. "Notas a las Notas a las Notas... a Porpósito de Manuel Puig" en Revista Iberoamericana. 76-77. (1971): 555-567.

Sarlo, Beatriz. Jorge Luis Borges: A writer on the edge. Ed. John King. University of Cambridge, Massachusetts. 1993.

Selden, Raman. La teoría literaria contemporánea. Trad. Juan Gabriel López Guix. Barcelona: Ariel. 1987.

Severo Sarduy. Dir. Julián Rios. Caracas: Fundamentos. 1976.

Shaw, Donald L. Nueva narrativa hispanoamericana. Madrid: Cátedra. 1992.

Tanner, Tony. "Borges and American Fiction: 1950-1970." Alazraki, Critical. 165-173.

Teuber, Bernardo. Fragmentos en torno a su imán. Tr. Carol Santamarina y Bernardo Teuber. München: Lagrev-Verlag. 1994.

Todorov, Tzvetan. The Fantastic: A Structural Approach to a Literary Genre. Trans. Richard Howard. New York: Cornell University Press. 1989.

Villena, Luis Antonio de. "Lezama Lima: 'Fragmentos a su imán' o el final del festín," Voces. 65-71.

Vitier, Cintio, y Fina García marruz. "La amistad tranquila y alegre, en eco de mucho júbilo." Espinosa 48-84.

Vitier, Cintio. "En torno a la poesía de Jorge Luis Borges." Orígenes. 2.6 (1945): 33-42.

---. “La aventura de Orígenes." González Cruz 309-337. 
---. "La poesía de Lezama Lima y el intento de una teleología insular.” Voces. 46-64.

Voces: Lezama Lima. Barcelona: montesinos. 2. 1982.

Wall, Catharine E. "Word and Image in the Hispanic Avant-Garde." Unpublished essay, 2002.

Yudin, Florence L. Nightglow: Borges' Poetics of Blindness. Salamanca: Universidad Pontificia de Salamanca. 1997.

Yurkievich, Saúl. La movediza modernidad. Madrid: Taurus. 1996.

---. “Jorge Luis Borges y Ramón Gómez de la Serna: el reflejo recíproco.” Lafuente 7393.

Zaldivar, Gladys. Novelística Cubana de Los Años 60: Paradiso, El mundo alucinante. Miami: Ediciones Universal. 1977. 


\section{Bibliografia consultada}

Arana, Juan. El centro del laberinto. Los motivos filosóficos en la obra de Borges. Pamplona: Eunsa. 1994.

Balandier, Georges. El desorden. La teoría del caos y las ciencias sociales. Barcelona: Gedisa. 1993.

Bejel, Emilio. José Lezama Lima, poet of the image. Gainesville: University of Florida Press, 1990.

Cañeque, Carlos. Conversaciones sobre Borges. Barcelona: Destino. 1995. Doyle, Raymond H. La huella española en la obra de Jorge Luis Borges. Madrid: Playor. 1977.

Escohotado, Antonio. "Caos como regeneración política," Archipiélago 13. (1993): 3538.

Escohotado, Antonio. “Sobre caos y orden,” Claves de razón práctica. Madrid:

Promotora general de revistas. 21. (abril 1992): 28-31.

Escohotado, Antonio. Caos y orden. Madrid: Espasa Calpe. 1999.

Ette, Ottmar. La Escritura de la Memoria: Reinaldo Arenas; textos, estudios y documentación. Frankfurt am Main: Vervuert, 1991.

Ferrari, Osvaldo, ed. y prol. Diálogos últimos. Buenos Aires: Editorial Sudamericana, 1987.

Hayles, N. K. ed. Chaos and Order. Chicago: The University of Chicago Press. 1991.

Herrera Zapien, Tarcisio. “La revelación de Virgilio en Borges.” Plural. 201. (1988): 1014.

Huici, Adrián (1998): El mito clásico en la obra de Jorge Luis Borges: El laberinto. Sevilla: Alfar. 1998.

Huici, Adrián. "Infinito y Entropía: la inútil inmortalidad y la biblioteca muerta de Borges," Antigonía. 1. (1996): 35-45.

Jurado, Alicia. Genio y figura de Jorge Luis Borges. Buenos Aires: Editorial Universitaria. 1964.

Márquez, Enrique. Bases y génesis de un sistema poético. New York: Peter Lang. 1991. 
Martín-Pereda, José A. y Ana González Marcos. "Repercusiones de la Teoría del Caos sobre los planteamientos de la Ciencia y la Tecnología: ¿Interdisciplinariedad o especialización?” Arbor CSIC. CXLV. 571. (julio 1993): 107-120.

Prigogine, Ilya. Las leyes del caos. Traducción de Juan Vivanco. Barcelona: Crítica. 1997.

Rivera, Juan Antonio. "El efecto mariposa," Claves de razón práctica. 73. (Junio 1997): $32-41$.

Rodríguez Carranza, Luz. "Réquiem por un fin de siglo," Anthropos. 142-143. (marzoabril 1993): 87-91.

Roldán Castro, Ismael. Caos y comunicación: la teoría del caos y la comunicación humana. Sevilla: Mergablum. 1999.

Rollason, Christopher. "Borges' 'Library of Babel' and the Internet." Http://www.rpg.net/quail/libyrinth/borges/borges_papers_rollason.2.html 1999.

Shaw, Donald. Borges: Ficciones. Londres: Grant \& Cutler. 1976.

Sorman, G. Los verdaderos pensadores de nuestro tiempo. Barcelona: Seix Barral. 1991.

Stoicheff, Peter. "The Chaos of Metafiction," Chaos and Order. Hayles, N. K. ed. Chicago: The University of Chicago Press. (1991): 85-99.

Ulloa, Justo C. Ed. José Lezama Lima: Textos Críticos. Miami: Ediciones Universal, 1979.

Ulloa, Leonor A. De. “ Cangrejos, Golondrinas: Metástasis textual.” Revista Iberoamericana. 57.154 (1991): 91-100.

Vázquez, María Esther. "Reflexiones acerca de 'La Biblioteca de Babel'," Anthropos. 142-143. (marzo-abril 1993): 97-104.

Vizcaíno, Cristina. Ed. Coloquio internacional sobre la obra de José Lezama Lima. 2 vols. Madrid: Fundamentos, 1984.

VVAA. "Complejidad en la frontera del caos," Investigación y Ciencia. 236 (mayo 1996): 14-21.

VVAA. "El lenguaje de los fractales," Investigación y Ciencia. 169. (octubre 1990): 4657. 
Weissert, Thomas P. "Borges's Garden of Chaos Dynamics," Chaos and Order. N. K. Hayles, ed. Chicago: The University of Chicago Press. (1991): 223-243.

Yurkievich, Saúl. "La expresión americana o la fabulación autóctona.” Revista Iberoamericana. 57.154 (1991): 43-50.

---. Barroco Buenos Aires: Sudamericana, 1974.

Zilio, Giovanni M. "La enumeración 'caótica' en la poesía del último Borges," Anthropos. 142-143 (marzo-abril 1993): 138-140. 


\section{Notas}

${ }^{1}$ Se refiere a la geografía mental desde donde se conforma y hacia donde retorna la realidad fictiva. Las obras de estos escritores operan dentro del campo metafórico en una gran proporción. Esto es, no tienen un referente inmediato o geográfico concreto. Están hechas para ser decodificadas por el lector y ubicadas en su sico-grafía. Son altamente metaliterarias.

${ }^{2}$ Cito a continuación los trabajos directamente enfocados en el tema, aunque existen algunos otros artículos que mencionan a Lezama y a Borges en un mismo contexto sin desarrollo ulterior. El primero es la tesis de Mark Richard Couture. Éste realiza un recorrido exhaustivo sobre puntos de intersección entre Borges y Lezama, sobre todo en cuanto al barroco y al concepto del criollismo. Considera también a Borges un precursor de Lezama (260). Couture, Mark Richard. Secret Accomplices: Jorge Luis Borges and José Lezama Lima Read the Poetry of the Spanish Golden Age. Duke University. 1995. El segundo texto contrapone las opiniones de Borges y Lezama respecto a Joyce en una revisión sobre el barroco. Salgado, César Augusto. "Barroco Joyce: Jorge Luis Borges's and José Lezama Lima's antagonistic readings" en Transcultural Joyce. Lawrence, Karen R. ed. and introd. England: Cambridge UP. 1998.

${ }^{3}$ Según Guillén: "La vieja noción de periodo como concepto que aspira a coincidir plenamente con un segmento de tiempo y que de tal suerte constituye una unidad singular de la historia literaria, queda descartada [. . . ] la noción de periodo como a la vez continente y contenido ya no es aceptable" (124). En mi desarrollo considero la evolución histórica de la poética como un acierto del que se valen los escritores, pero que a su vez convive simultáneamente con infinitas formas, estilos, corrientes de creación pertenecientes a distintos periodos de la evolución de la literatura. Por eso, al hablar de Borges y Lezama comparo sus poéticas en cuanto a ciertos valores arquetípicos o universales que definen y diferencian la literatura profunda de otras formas del lenguaje más superficiales. Borges y Lezama se encuentran en cierto centro donde se daría una especie de poética teórica versus la poética aplicada de una literatura más inmediata y comunicante.

${ }^{4}$ Un compendio amplio sobre la relación de Borges y Lezama con los escritores del Siglo de Oro y el Barroco se encuentra en: Secret Accomplices: Jorge Luis Borges and Jose Lezama Lima read the poetry of the Spanish golden age de Mark Richard Couture y "Barroco Joyce: Jorge Luis Borges's and Jose Lezama Lima's antagonistic readings." de César Augusto Salgado. Véase la revisión sobre ideas de Vico que Lezama hace en "Las eras imaginarias," páginas 42-43.

${ }^{5}$ Cito del prólogo de Emilio de Armas "Para Lezama, el poema es 'un cuerpo resistente frente al tiempo y el poeta es el guardián de la semilla, de la posibilidad, del potens. Eso lo sacraliza' [...] La fuerza del potens, que engendra a partir de sí mismo y de la sobreabundancia, se tiende a través de cada 'oscuro dominio impenetrable’ hacia nuevas y contingentes apropiaciones de la realidad” (Lezama, Poesía 21).

${ }^{6}$ Eloísa Lezama Lima toma la cita de una entrevista en Cuba Internacional, La Habana. Enero. 1971.

${ }^{7}$ El color local que a veces se observa en los textos de Lezama está dado por su focalización microespacial y no se debe confundir con un localismo de la poesía. "Rapsodia para el mulo" o "Una inmensa pradera me convida" denotan un color local y usan una semántica criolla pero la concatenación metafórica que se logra con esos mismos elementos connota un imaginario universal. La poesía deviene proposición artística.

${ }^{8}$ Es interesante que donde Virgilio Piñera ve enajenación, Vitier ve criollismo: "Piñera, unlike Vitier, focuses not on the criollismo of argentine writers like Borges, but on the opposite extreme" (Couture 248). Ambos buscan la quintaesencia de la expresión americana a partir de una revisión del eurocentrismo. Pero basta leer las reflexiones de Borges sobre los orilleros y sus memorias sobre Adrogué para entender su profunda dimensión nacional.

${ }^{9}$ Saúl Yurkievich, en su artículo "Jorge Luis Borges y Ramón Gómez de la Serna: el reflejo recíproco," anota el poco caso que Borges dedica a las artes plásticas: "En esta única referencia de Inquisiciones a las artes plásticas, Borges, que generalmente las ignora, alude al periodo cubista de Pablo Picaso" (83, notas). 
${ }^{10}$ Para Lezama la metáfora tiene una fuerza autoreplicadora que es recurrente en su obra a través de distintas perspectivas. Semejante idea presenta Borges al sugerir que las metáforas existen en los arquetipos y estos nos las sugieren. Hoy día una teoría que es complemento a estas ideas se encuentra en los trabajos de la doctora Susan Blackmore: "The Power of Memes", in Scientific American, Vol 283 No 4, October 2000: 52-61. "As different actions and vocalizations competed in the prehistoric meme pool, such spoken words would prosper and displace less well adapted memes of communication. Then, stringing words together in different orders, and adding prefixes and inflections, would provide fertile niches for new, more sophisticated vocal memes. In sum, the highest-quality replicable sounds would crowd out the poorer ones." Véase también The Selfish Gene by Richard Dawkins. Oxford University Press. 1976.

${ }^{11}$ El citado trabajo de Couture ofrece una importante relación de artículos dedicados al estudio de Orígenes (237). También hace una revisión minuciosa sobre vínculos entre Borges y Lezama en la sección V del mismo (235-260). La tesis se centra en probar que Borges y Lezama fueron afines en su lectura y absorción de la estética de Siglo de Oro, aunque va mas allá de ese propósito. También presenta a Borges como precursor de Lezama en cierto sentido (260), pero reconoce diferencias originales. Mi tesis intenta demostrar que las estéticas de estos autores fueron afines e independientes. Mi acápite sobre la vinculación entre ambos se hace necesario para probar que aunque ambos no desconocieron sus obras recíprocamente y a pesar de la afinidad, sus estéticas e intenciones venían desde antes alimentadas por la filosofía y la revolución literaria. Sin este acápite mi tesis dejaría un vacío metodológico al suponer una serie de vínculos y perspectivas compartidas y no hablar de la historia simultánea.

${ }^{12}$ Para otras referencias sobre Borges véase Secret Accomplices: 236-37.

${ }^{13}$ Se ha documentado una abierta posición anticomunista en Borges. Según Bell-Villada: "The art of every author also has its social origins and functions, however, and the content of some of Borges's best stories expressed in their time the antifascism, anticomunism, and antipopulism of the older liberal, Anglophile elites of Argentina (285).

${ }^{14}$ En una conversación con Armando Álvarez Bravo, Lezama explica: "Encontré la palabra potens, que según Plutarco representaba en el toscano sacerdotal el si es posible, la posibilidad infinita que después observamos en el virgo potens del catolicismo...y llegué a la conclusión de que esa posibilidad infinita es la que tiene que encarnar la imagen" (22).

${ }^{15}$ Hemos obviado aquí los comentarios que ha hecho Lezama en cartas a su hermana y otros de menos argumento por considerar que la sección cuenta con suficiente prueba según nuestro propósito. Para estos comentarios se puede consultar Cartas 1939-1976 ed. Eloisa Lezama Lima. Madrid: Orígenes. 1979.

${ }^{16}$ La crisis de Orígenes se conoció en Argentina. E. Sábato, en una carta a Lezama fechada el 18 de marzo ( $\sin$ año), se expresa sobre el tema en estos términos: "Acá nos enteramos hace unos pocos días [sobre el conflicto] y lo hemos lamentado infinitamente, por la obra cultural seria y de jerarquía que todos ustedes realizaban desde Orígenes. No quiero yo -ni podría- tomar partido en un conflicto tan lamentable; ya que, aparte de nuestra falta de información sobre los matices que siempre hay en esta clase de polémicas, tengo muchos motivos de gratitud por el grupo de ustedes y por Rodríguez Feo.” Más adelante el escritor agrega: "Por este mismo correo le escribo a Rodríguez Feo en términos parecidos" (González, Cruz 303).

${ }^{17}$ Paralelo al decir de Michel Foucault, en versión de Raman Selden: "Nunca podemos conocer el archivo de nuestra propia época porque es el Inconsciente [sic] desde el que hablamos" (Selden 121). Tampoco podemos evaluar la no originalidad estética de una obra cuya no originalidad se basa en la existencia de un código desconocido, nos da a entender Borges.

${ }^{18}$ Cintio Vitier explica en un estudio sobre Orígenes cómo el concepto de lo "natural maravilloso" nace antes que lo "real maravilloso" de Carpentier y relacionado con el catolicismo. Cintio cita de un artículo de Lezama aparecido en Grafos: "No la hiriente y miserable sorpresa, doble, triple fuga, sino el acompañamiento de lo natural maravilloso, de tamaño visible, o simplemente poético" (Vitier, "La 
aventura" 313), y más adelante: "Vemos cómo el hallazgo de "lo natural maravilloso", consignado nueve años antes que "lo real maravilloso" del prólogo de Alejo Carpentier a El reino de este mundo, y sin ninguna intención de manifiesto, vuelve a relacionarse con el mundo de la catolicidad, lo cual sin duda es un punto clave, aunque no exclusivo, para entender a Orígenes" (314).

19 "Porque la filosofía es todo ficción, realmente" (Borges el memorioso 82), asevera Borges. Luego se refiere a textos religiosos de San Agustín, Santo Tomas, Rothe: "Es decir, yo, que no soy creyente, leí aquello como si leyera una obra fantástica" (Ibíd 83).

${ }^{20}$ En el libro: Lezama Lima: Una cosmología poética. Las autoras demuestran el esoterismo y el platonismo de Lezama en "Muerte de Narciso": "Tanto más aguda como profunda es la influencia platónica en Lezama, hasta el punto de considerar, por nuestra parte, susceptible de calificarse su posición filosófica básicamente como platonismo" (Rensoli 63). También págs 55-65

${ }^{21}$ Sarduy documenta una investigación llevada a cabo por el United States Biological Survey realizado a vísceras de 80,000 pájaros que demuestra la inutilidad del mimetismo (La Simulación 16). La cita incluída en la cita de Sarduy corresponde a: Roger Callois, Méduse et Cie. NFR, Gallimard. 1960: 99.

22 Éste es el fragmento de texto en cuestión a que se refiere y cita Suzanne Jill Levine: “[ . . .] lo libraban de la vista, del oído, del tacto, del día, de la infamia, del tiempo, de los bienhechores, de la misericordia, del aire, de los perros, del universo, de la esperanza, del sudor y de él mismo" (102) (Borges, Obras completas 1:299).

${ }^{23}$ Lezama explica lo hipertélico de esta manera: "Existe también lo que pudiéramos llamar el camino o método hipertélico, es decir, lo que va siempre más allá de su finalidad venciendo todo determinismo. Otro ejemplo. Durante mucho tiempo se creyó que las convulvas, que son unos vermes ciliares, retrocedían hasta donde llegaba la marea. Pero se ha podido observar que cuando no hay marea retroceden a la misma distancia" (Órbita 24-25).

${ }^{24}$ Reinaldo Arenas cuenta cómo se reprimía el homosexualismo en Cuba. Véase (Antes que Anochezca 71). Arenas también comenta la censura a que fue sometida la novela Paradiso (Antes que anochezca 111).

${ }^{25}$ (Quintiliano, libro VIII, 6, 44).

${ }^{26}$ Según la definición de Northrop Frye: "Archetypes are associative clusters, and differ from signs in being complex variables. Within the complex is often a large number of specific learned associations which are communicable because a large number of people in a given culture happen to be familiar with them" (Anatomy of Criticism 102). 
VITA

JOSE R VILAHOMAT

2002-present

$1998-2001$

$1998-2001$

1999

1997

1992
Spanish Instructor

Hendrix College

Conway, Arkansas

Adjunct Professor

Florida International University

Miami, Florida

Spanish and Social Studies Teacher

MDCPS/ Corporate Academy North

Miami, Florida

A.B.D. in Spanish

Florida International University

Miami, Florida

M.A. in Spanish

Florida International University

Miami, Florida

B.A. in Spanish

Universidad de la Habana

Havana, Cuba

\section{PUBLICATIONS AND PRESENTATIONS}

“Jorge Luis Borges y Jose Lezama Lima: El juego de las confluencias abstractas." Presented at thrird FIU Conference on Iberian/Iberian-American Literature and Film ("New trends in Hispanic Literature and Film") November 2001.

"El Reino de este mundo como explicación del reino de este mundo."Presented at Second FIU-UM Conference on Iberian/Iberian-American Literature ("1999: Hispanic Literature and Film at the End of the Millennium") October 1999. 